\title{
ANÁLISE DA ARMAZENAGEM E DOS PREÇOS DE MILHO NO ESTAdO de SÃo PAULO
}

DAVI GUILHERME GASPAR RUAS

Orientador: Geraldo Sant'Ana de Camargo Barros

Dissertação apresentada à Escola Superior de Agricultura "Luiz de Queiroz", da Universidade de São Paulo, para obtenção do titulo de Mestre em Economia Agrária.

PIRA CICABA

Estado de São Paulo - Brasil

Fovereiro, 1978 
11.

A minha esposa Tereza Cristina Aos meus pais Josē e Adelaide 


\section{AGRADEC IMENTOS}

A Empresa Brasileira de Pesquisa Agropecuária - EMBRAPA, pela oportunidade oferecida para frequentar o Curso de Pós-Graduação, além do suporte financelro a esta pesquisa, que integra o "Projeto Milho" em desenvolvimento através do Convênio EMBRAPA/ESALQ.

Ao Professor Geraldo Sant'Ana de Camargo Barros, pela valiosa or1entação oferecida.

Aos Professores Rodolfo Hoffmann e José Ferrelra de Noronha, pela le1tura dos originals deste trabalho, enriquecendo-o com importantes sugestões e comentārios.

Aos Professores e funcionários do Departamento de Ciènclas Socla1s Aplicadas da ESALQ, que direta e indiretamente colaboraram com esta pesquisa.

Aos colegas do curso pelo estímulo e apolo na realização deste trabalho.

Ao Setor de Processamento de Dados do. Departamento de Matemática e Estatistica da ESALQ, pelos serviços prestados.

A Fundação Ford, pelo suporte financeiro para a publicação deste trabalho.

A todos que direta ou indiretamente contribuiram na realização des te trabalho. 


\section{TNDICE}

Pàg.

LISTA DE TABELAS $\ldots \ldots \ldots \ldots \ldots \ldots \ldots \ldots \ldots \ldots \ldots \ldots \ldots$ vi

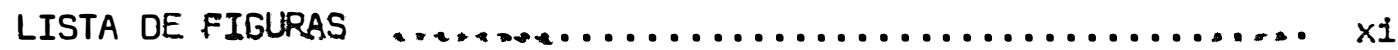

RESUMO $\ldots \ldots \ldots \ldots \ldots \ldots \ldots \ldots \ldots \ldots \ldots \ldots \ldots \ldots \ldots \ldots \ldots \ldots \ldots \ldots \ldots$

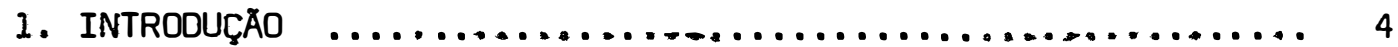

1.1 - O Prablema $\ldots \ldots \ldots \ldots \ldots \ldots \ldots \ldots \ldots \ldots \ldots \ldots \ldots \ldots \ldots$

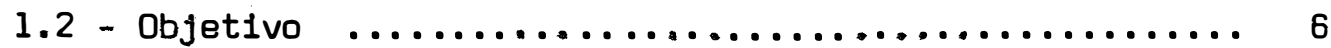

2. REVISÅO OE LITERATURA $\ldots \ldots \ldots \ldots \ldots \ldots \ldots \ldots \ldots \ldots \ldots \ldots \ldots$

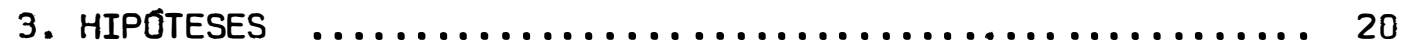

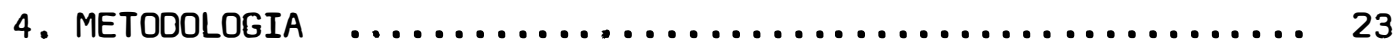

4.1 - Area de Estudo e Fonte de Dados ............... 23

4.2 - Margem de Comercialização .................... 24

4.2 .1 - Determinação das Margens ............. 25

4.2.2 - Fatores que afetam as margens de comerciallza

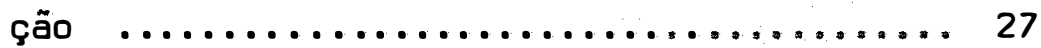

4.2 .3 - Limitaçöes no cálculo de margens ......... 28

4.3 - Anālise Econométrica das Polfticas de Margem de Comer

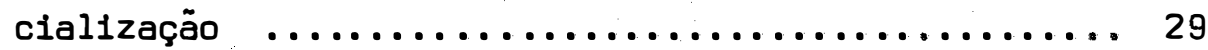

4.4 - Elastıcidade de Transmissão de Preço ........... 34

4.5 - Varıação Estacional ..................... 36

4.5.1 - Fundamentos para cálculo da varlação estacio-

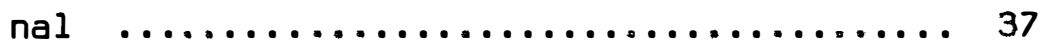

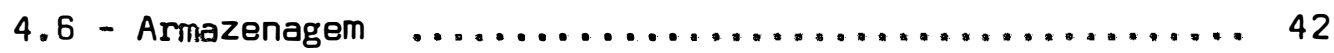

4.6 .1 - Modelo de demanda de armazenagem ........4 43

4.6 .2 - Estimação e teste do modelo ............4 46

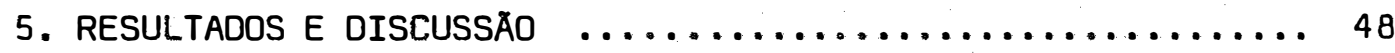

5.1 - Margem de Comerclalização ................ 48

5.2 - Anälı̀ Econométrica das Margens ................ 54 
Pág.

5.3 - Elasticidade de Transmissão de Preço ............ 58

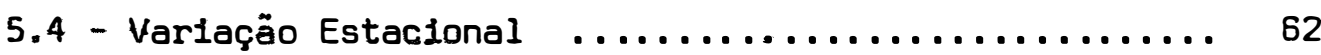

5.5 - Armazenagem $\ldots \ldots \ldots \ldots \ldots \ldots \ldots \ldots \ldots \ldots \ldots \ldots \ldots \ldots . \ldots \ldots$

5.5 .1 - Demanda de armazenagem $\ldots \ldots \ldots \ldots \ldots \ldots . \ldots 75$

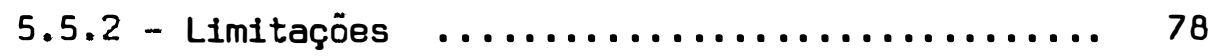

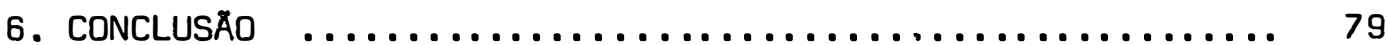

6.1 - Principais Implicações da Pesquisa $\ldots \ldots \ldots \ldots \ldots . \ldots . . . .62$

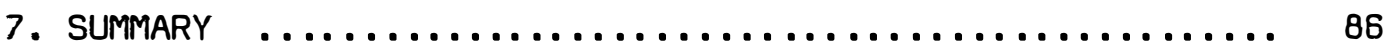

8. LITERATURA CITADA $\ldots \ldots \ldots \ldots \ldots \ldots \ldots \ldots \ldots \ldots \ldots \ldots . \ldots . \ldots . \ldots . \ldots$

APENDICE $1 \quad \ldots \ldots \ldots \ldots \ldots \ldots \ldots \ldots \ldots \ldots \ldots \ldots \ldots \ldots \ldots \ldots \ldots$

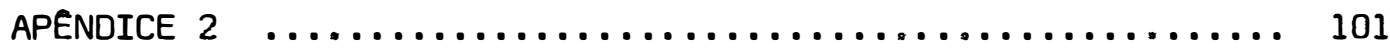

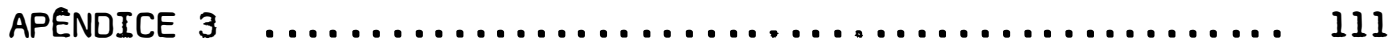


vi.

\section{LISTA DE TABELAS}

TABELA

Pág.

1 Tipos de pollticas de margem ................ 31

2 Caracterização da polftica de "markup" em função do sinal da estimativa e de resultado do teste $t$ paraos

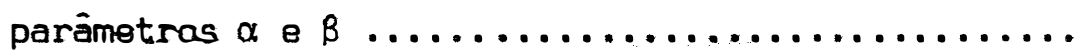

3 Médias mensais da margem do atacadista, da margem do varejista e da margem de comercialização, em porcentagem do preço do milho no varejo, no Estado de São

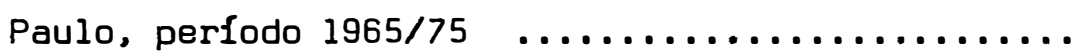

4 Estimativas das médias anuais das margens do atacadista, do varejista e de comercialização, para o Estado de São Paulo, período 1965/75. Valores expres-

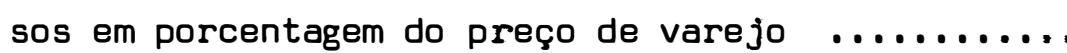

5 Estimativa dos parâmetros da regressão linear da mar gem do atacadîsta em relação ao preço recebido pelo produtor, valores do teste $t$, coeficiente de determinação e caracterização da polftica de "markup" na co mercialização do milho no Estado de São Paulo, perío

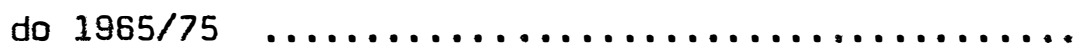

6 Estimativa dos parâmetros da regressão linear da mar gem do varejista em relação ao preço no atacado, valores do teste $t$, coeficiente de determinação e caracterização da polftica de "markup" na comercializa ção do milho no Estado de São Paulo, perfodo 1965/75

7 Estimativa dos parámetros da regressão linear da mar gem de comercialização em relação ao preço recebido 
vii.

TABELA

Pág.

pelo produtor, valores do teste $t$, coeficiente de de terminação e caracterização da polftica da "markup" na comercialização de milho no Estado de São Paulo,

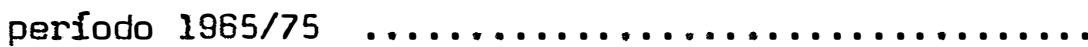

8 Elasticidade de transmissão de preço expressando a porcentagem de variação no preço de varejo com a variação de 1 por cento no preço do produtor, para o milho no Estado de São Paulo, perf́odo 1965/75 ..... 59

9 Elasticidade de transmissão do preço, expressando a porcentagem de variação no preço do atacado com a va riação de 1 por cento no preço do produtor, para o

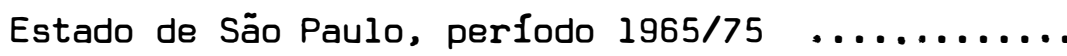

10 Elasticidade de transmissão de preço, expressando a porcentagem de variação no preço de varejo, com a va riação de 1 por cento no preço de atacado, para o mi tho no Estado de São Paulo, período 1965/75 .......

11 Variação estacional do preço do milho, Indices obtidos por meio de média móvel geométrica, utilizando preços correntes (CI $\$ / 60 \mathrm{~kg}$ ) recebidos pelos produto res do Estado de São Paulo, período 1965/76 .......

12 Variação estacional do preço do milho, Indices obtidos por meio da média móvel geométrica, utilizando preços correntes ( $C r \$ / 60 \mathrm{~kg}$ ) ao nível de atacado no Estado de São Paulo, período 1965/76 ............

13 Variação estacional do preço do milho, índices obtidos por meio da média móvel geométrica, utilizando preços correntes ( $\operatorname{Cr} \$ / 60 \mathrm{~kg}$ ) ao nível de varejo no Estado de São Paulo, período 1965/75 ............ 
viii.

TABELA

Pág.

14 Indices sazonais, limites de variação superior e inferior, relativos aos preços médios mensais do milho no produtor, atacado e varejo, para o Estado de São

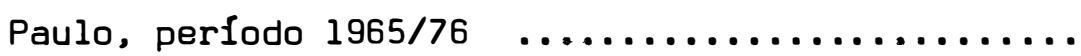

15 Participação do volume máximo, médio e mínimo anual de milho armazenado, na capacidade de armazenagem do

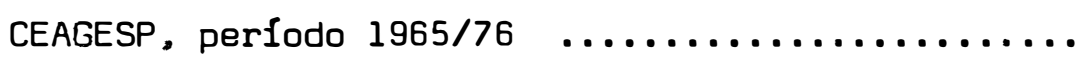

16 Produção, quantidade máxima armazenada e porcentagem de armazenado em relação à produção, no CEAGESP, pe-

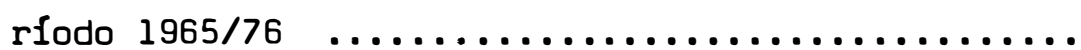

17 Evolução da produção de milho no Estado de São Paulo, da capacidade de armazenagem do CEAGESP e dos estoques máximos de milho, perfodo de 1965 a 1976, em to

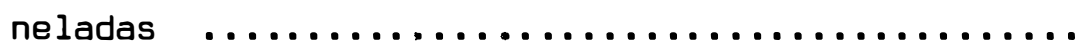

18 Resultado do ajustamento da forma reduzida, perfodo

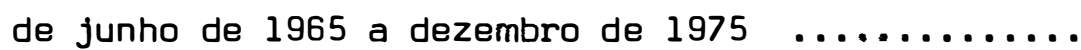

19. A Preços médios de milho recebidos pelos produtores do Estado de São Paulo, perfodo de 1965/76, em cruzei-

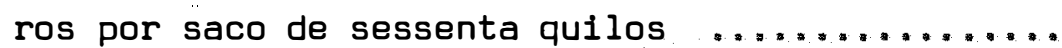

19.B Preços médios de milho, deflacionados pelo "Indice 2" da F.G.V., recebidos pelos produtores do Estado de São Paulo, perfodo de 1965/76, em cruzeiros de $1965 / 67$ por saco de sessenta quilos ........... 95

20.A Preços médios mensais de milho no atacado da cidade de São Paulo, perfodo de 1965/76, em cruzeiros por saco de sessenta quilos ................. 96 
20.B Preços médios mensais de milho, deflacionados pelo "Indice 2" da F.G.V., no atacado da cidade de São Paulo, perfodo de 1965/76, em cruzeiros de 1965/67 por saco de sessenta quilos $\ldots \ldots \ldots \ldots \ldots \ldots \ldots \ldots$

21.A Preços médios de milho no varejo do Estado de São Pau 10, perfodo de 1965/75, em cruzeiros por saco de ses

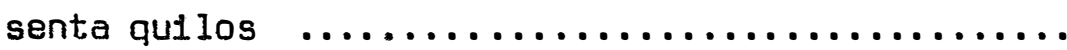

21.B Preços médios de milho, deflacionados pelo "Indice 2" da F.G.V., no varejo do Estado de São Paulo, perfodo de 1965/75, em cruzeiros de 1965/67 por saco de sessenta quilos $\ldots \ldots \ldots \ldots \ldots \ldots \ldots \ldots \ldots \ldots \ldots \ldots$

22 Estoques de milho na Companhia de Entrepostos e Arma zéns Gerais do Estado de São Paulo, perf́odo 1965/76, em toneladas

23 Estimativas das Margens de Comercialização do milho, para o Estado de São Paulo, perfodo 1965/75, expresso em cruzeiros reais $(1965-67=100)$ por saco de ses

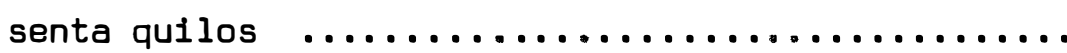

24 Estimativas das Margens de Atacado do milho, para o Estado de São Paulo, perfodo 1965/75, expresso em cruzeiros reais $(1965-67=100)$ por saco de sessenta qu1 los ................................. 103

25 Estimativas das Margens de Varejo do milho, para o Estado de São Paulo, perfodo 1965/75, expresso em cru zeiros reais $(1965-6)=100\}$ por saco de sessenta qui los 
26 Estimativas das Margens de Comercializeçäo parcentual e média mensal, para o Estado de São Paulo, perfo-

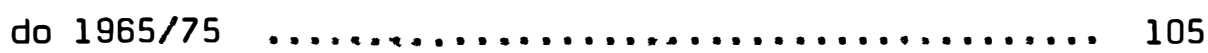

27 Estimativas das Margens de Atacado porcentual e média mensal, para o Estado de São Paulo, perfodo 1965/ 75

28 Estimativas das Margens de Varejo porcentual e média mensal, para o Estado de São Paulo, perfodo 1965/75 107

29 Estimativas da participação porcentual do produtor em relação ao preço do varejo, para o Estado de São Pau

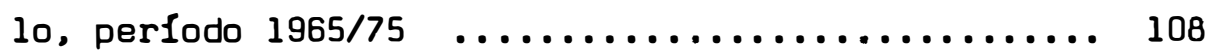

30 Estimativas do "markup" porcentual do atacado e média mensal, para o Estado de São Paulo, perfodo 1965/ 75

31 Estimativas do "markup" porcentual do varejo e média mensal, para o Estado de São Paulo, perfodo 1965/75 110

32 Análise de variância dos fndices do produtor ..... 112

33 Análise de variância dos indices do atacado ...... 112

34 Análise de variância dos fndices do varejo $\ldots . . . .112$ 


\section{LISTA DE FIGURAS}

FIGURA

Pág.

1 Médias mensais da margem do varejista, do atacadista e do produtor de milho, em porcentagem do preço no varejo, no Estado de São Paulo, perfodo 1965/75 ... 50

2 Evolução das médias anuais das margens do atacadista, do varejista e de comercialização, para o Estado de São Paulo, período 1965/75. Valores expressos em por centagem do preço de varejo $\ldots \ldots \ldots \ldots \ldots \ldots \ldots \ldots . . . . .53$

3 Variação estacional dos preços médios do milho recebidos pelos produtores do Estado de São Paulo, 1965/

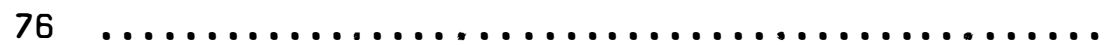

4 Variação estacional dos preços médios do milito no atacado do Estado de São Paulo, 1965/76 ......... 68

5 Variação estacional dos preços médios do milho no va rejo do Estado de São Paulo, 1965/75 ........... 69

6 Evolução da produção de milho, capacidade de armazenagem do CEAGESP e dos estoques máximos de milho, no Estado de São Paulo, perIodo 1965/76. Indices: 1965 igual a 100 
RESUMO

0 presente trabalho analisa diversas aspectos de pre ço e de decisão quanto à armazenagem de milho no Estado de São Pau10. Apresenta-se inicialmente uma pequena introdução que inclui o problema e sua importância. No capítulo seguinte é feita a revisão de literatura.

No capítulo da metodologia é feita uma exposição a respeito dos dados utilizados no trabalho e também a respeito dos métodos empregados. Discute-se então, a análise da margem de comercialização assim como sua análise econométrica. Dessa ültima calcu la-se a elasticidade de transmissão de preço. Ainda na metodologia apresenta-se o método de análise da variação estacional de preços utilizando-se da média geométrica móvel. Por último discute-se o mo delo para análise do efeito de expectativas de preço na armazena- 
gem de milho no CEAGESP. Para este fim usa-se um modelo de defasagem distribuida.

Na parte de resultados, verificou-se que a margem de comerclalização média do milho no Estado de São Paulo, no período 1965/75 foi em torno de 43,9\% do preço do varejo. A participação mé dia do produtor no preço de varejo foi de $56,1 \%$ no período da pesquisa, a do varefista foi de $30,5 \%$ e a. do atacadista de $13,4 \%$.

Quanto à análise econométrica, o "markup" relativo mostrou-se decrescente em todo o perfodo, para os três níveis a não podemos rejeitar a hipótese de que a margem absoluta é constante. Fa zendo análise da elasticidade de transmissã̃o de preço, observa-se que sempre foi menor do que 1 . Em média no período de 1965/75 as elastıcidades de transmissão de preço foram as seguintes: 0,$4 ; 0,76$ e 0,47 respectivamente para elasticidade total, do atacado e do va rejo.

A amplitude de variação do Indice sazonal para o produtor, atacadista e varefista foi respectivamente 28,$3 ; 20,7$ e 14,5, portanto o preço recebido pelos produtores variaram mais do que os do atacado e estes mais do que os do varejo.

Analisando os dados sobre quantidade de milho armaze nada no CEAGESP, no período 1965/76, verificou-se que em média, o milho ocupou $14 \%$ da capacidade total, o que representa $7,1 \%$ da produção médía do Estado no período.

Quanto à expectativa de preço futuro dos usuários do CEAGESP, os resultados foram os seguintes: (a) a elasticidade-preço 
de curto prazo (com respeito ao preço do mês) sugere que se ocorrer uma variação de 10\% no preço do mês em relação ao mês anterior, haverá uma varíação de $6,3 \%$ nos estoques do mês em relação ao do mês anterior, mas em sentido conträrio: (b) a elasticidade-preço de lon go prazo (com respeito ao preço esperado no mês seguinte) sugere que uma variação de $10 \%$ no preço esperado para o mês seguinte em relação ao preço do mês leva a uma variação de $10,9 \%$ nos estoques no mesmo sentido.

Dos resultados obtidos são extraídas implicações de ordem teórica e política, ressaltando o papel das polfticas de crédito para comercialização e de armazenagem, visando uma redução nas oscilações de preços e uma regularização do abastecimento do mí Iho. 


\section{INTRODUÇĀO}

A comercialização é um dos pontos de maior interesse na economia rural. Por seu intermédio, a demanda dos consumidores é satisfeita tanto na quantidade de produto como também na forma dese jada, no tempo adequado e no lugar conveniente.

Menores custos de comercialização, com o uso da tecnologia existente, poderäo concorrer para um maior ganho para o pro dutor, bem como diminuir os preços para os consumidores.

\section{1 - 0 Problema}

a milho é uma cultura muito difundida no Brasil. Segundo a SUPLAN (1975) "da área total cultivada no Brasil, no período $1968 / 72,27,7 \%$ correspondiam ao milho, revelando um pequeno aumento em relação a 1959/63, quando essa participação era de 25,9\%". 
a Estado de são Pauia ocupa o terceiro lugar como pro dutor, logo abaixo do Paraná e Minas Gerais; sua produção é aproximadamente 15\% da nacional (SUPLAN, 1975). No Estado o milho é o quin to produto agrícola em importāncia económica na agricultura (PROGNÓS TICO 75/76).

No Brasil, em geral, o milho ê utilizado para os seguintes fins:

a) consumo "in natura" nas próprias propriadades, para alimentạ ção dos rebantios;

b) para alimentação humana;

c) como componente de raçōes balanceadas;

d) como matéría prima para as indüstrias alimentares lóleo, am1 do, etc.) e produtos químicos, industriais ou farmacêuticos (glìcose, álcool, etc.); e

e) para exportação.

Segundo JUNQUEIRA et alii (1968), "a relativa rigidez das margens em relação aos preços, é fruto principalmente dos elemen tos que compōem os custos e que são relativamente fixos, tais como transporte (cujo custo é determinado pela unidade física manipulada e não pelo valor do produto transportadol, aluguéis, impostos, etc.". Estes aspectos abrangem a cultura do milho, na hora de sua comercialização ou de armazenagem para venda futura, por ser um produto agrícola que apresenta uma das mais baixas relaçōes preço/volume. 
São ainda JUNQUEIRA et alii (1968) que dizem:"as mar gens podem se reduzir ou pela introduçäo de um melthoramento que reduza o custo de um serviça já prestado ou pela omissão de um serviço antes prestado".

Tendo em vista a importância da cultura do milho e os inúmeros problemas de sua comercialização agrícola,este trabalho pretende estudar alguns aspectos de importància da comercialização desse produto no Estado de Sãa Paulo.

\section{2 - objetivo}

0 principal objetivo deste trabalho é analisar econo micamente problemas importantes na comercialização do milho no Estado de São Paulo.

Mais especificamente, pretende-se:

I - Calcular as margens de comercialização nos diferentes níveis de mercado.

II - Estimar e identificar as variações das margens de comercia lização.

III - Obter indicaçöes sobre os tipos de políticas de "markup".

IV - Analisar as implicações económicas dos resultados para a política agrícola do governo e para as decisões de produtores e comerciantes.

V - Determinar o padrão de variação estacional de preços e aná lise das possíveis causas que determinam as mudanças cons- 
tatadas na amplitude da variaçäo

VI - Analisar o sistema de armazenagem estadual quanto à capací dade e nível de utilização no Estado de São Paulo.

VII - Estudar o comportamento dos usuärios do CEAGESP, quanto ao armazenamento de milho, em resposta a variações de preço. 


\section{REVISÃO DE LITERATURA}

Os trabalhos que existem no Brasil sobre comercializaçäo agrícola em sua maioria abordam somente aspectos de margem e de variação estacional separadamente. Os trabalhos que tratam somen te de um produto no geral são descritivos, isto é, descrevem como é feita a comercializaçāo. Segundo MARDIN (1962), "para melhorar a es trutura, operação e eficiēncia do sistema de comercialização, nōs temos que começar com situaçōes existentes. Isto, inicialmente, quer dizer estudos descritivos".

CASTRO (1972) descreve a evoluçäo da comercialização agrícola no Brasil. Diz que com o aparecimento dos atacadistas nos centros urbanos, estes acumularam um poder no processo de comercializaçäo, constituindo um ponto de estrangulamento. Diz ainda que "do ponto de vista económico, uma vez superados os pontos de estrangula mento, a margem de comercializaçāo, obtida através da especulaçāo, 
tende a reduzir-se através da concorréncia".

Segundo FRAGA (1960), "o abastecimento das cidades é feito com o contingente comercializado da produçāo, ficando assim na exclusiva dependência duma série de serviços como: os transportes, armazenagem, padronizaçāa dos produtos, embalagem, etc. Qualquer perturbaçāo que ocorra nessa grande série de serviços ou funções, tende a refletir-se no abastecimento das cidades". FRAGA colo ca ainda que "as deficiéncias de crödito, transportes, armazenagem, informaçōes comerciais, etc., conferem aos grandes intermediários (atacadistas, firmas industriais, exportadores, etc.) um grande poder sobre os preços, possibilitando manobras de várias naturezas no mercado".

BRANDT (1969a) diz que as .pesquisas de margem de co mercializaçāo deveriam explicar e quantificar as relações entre as margens e os fatores, como salários e fretes, entre outros, a que a possibilidade de reduçāo da margem de somercializaçāo depende, en tre outros fatores, da situaçāo competitiva e da eficiència operacional. Margens de comercializaçäo baixas, por si, näo indicam eficiência ou competiçāo.

BRANDT (s.d.) diz que um estudo de custo ou de margem de comercializaçāo é uma aproximaçāo ao estudo da eficiència de comercializaçāo. Em geral, envolve estudo de preços pagos, preços recebidos e práticas de manipulaçāo de produtos. Salienta, ainda, que a diferenȩe entre o preço recebido e o preço pago, por determinado intermediário, constitui a sua margem, porém isto indica pouco 
mais do que a quantia cobrada pela prestação de um serviço. Isto en razão de que ela não reflete o nümero de serviços prestados por este intermediário. E o que realmente parece importar, em julgamento de equidade, não são as parcelas em si prōprias, porém, os serviços prestados, os retornos totais e os lucros proporcionais.

JUNQUEIRA (1970) diz que para os produtores o conhecimento do que compōe as margens bem como seus valores é necessário para seguirem sempre a evolução da parcela que lhes cabe no custo do varejo, chamando a atenção daqueles que detèm o poder de decisão, quando alguma variação lhes for desfavorável.

Segundo MOSHER (s.d.), "a maioria dos produtores tem que vender seus produtos na fazenda ou no mercado local. Seu incentivo para produzir e vender, em vez de visar sua própria subsistēncia, depende, portanto, dos preços que eles podem receber. Estes preços dependem em parte da eficiència do sistema de comercialização que liga esses mercados locais com aqueles nas cidades".

DEXTER (1958), citado por BRANDT (1964), em trabalho de natureza descritiva, em que discutiu os fatores que influenciam os preços agrícolas, diz que a maior parte das variaçōes em preços agrícolas, dentro do ano, é gerada por variaçōes na rapidez com que os produtores comercializam sua produção, a qual, por sua vez, reflete os ciclos estacionais da natureza. Adiante, o autor diz que o grau de variação estacional dos preços depende da extensão permissí vel e do custo de estocagem. Além disso, as estimativas de flutuaçäo estacional deveriam ser usadas com cuidado, visto que se ba- 
seiam na experiència passada.

De acordo com STEELE (1971), "quanto maiores as variações na produção, maiores as variações nos preços. Igualmente, sendo as informações de mercado imperfeitas, ou inexistentes, mais variarão os preços". STEELE considera que na eficiência da comercia lização, os custos de produção e comercialização são usualmente influenciados pelas economias de escala e por melhoramento de adminis tração.

JUNQUEIRA (1967) coloca, entre os fatores que concor rem para alto custo de comercialização no Brasil, os seguintes:

"a) falta de meios de transporte adequados;

b) deficiència de estradas;

c) a falta de cuidados e previdência na manipulação e empacotamento, ocasionando desperdf́cios;

d) a ausência de uma classificação bem feita para os produtos agrícolas: e

e) um melhor aorimoramento do sistema de padronização."

KOHLS (s.d.) acentua que o conhecimento da comercialização e de seus problemas ajudará aos produtores a tomar as neces särias decisōes comerciais, e que um amplo conhecimento dos objetivos, organização e funcionamento da comercialização torna-se necessärio para um planejamento apropriado das atitudes a serem tomadas. Segundo a ANPES (1974), "os principais operadores no mercado atacadista de milho são os intermediärios, corretores, fir- 
mas de representação, indústrias, firmas exportadoras e atacadistas propriamente ditos. No Estado de São Paulo os atacadistas fazem cer ca de $55 \%$ de suas compras diretamente do produtor e $45 \%$ de intermediários. Os corretores e firmas de representação participam com $30 \%$ dos negócios realizados na capital paulista, ficando o restante rea lizado diretamente entre compradores e vendedores".

PEREIRA et alii (1963) estudaram a variaçāo estacional dos preços de 21 produtos agropecuários no Estado de São Paulo. Para o milho, no perlodo 1954/62, concluiram que maior Índice de ir regularidade era notado nos meses de altos preços e os menores índi ces de irregularidade nos meses de preços baixos ou próximos da média.

PANIAGO (1966) estimou a variaçäo estacional dos pre ços do milho no Estado de São Paulo, no período de 1951 a 1963 e fez análise das causas das flutuaçōes dos mesmos. Usou o método da média móvel de 12 meses e concluiu que o preço sofría decréscimo no perfodo de safra (abril a setembro) e acréscimo no período da entressafra (outubro a março). Obteve maior índice no mês de faneiro $(111,3)$ e menor em funho $(93,1)$.

HOFFMANN (1969a) obteve índices de variação estacional de 27 produtos agropecuários do Estado de São Paulo, utilizando o método da média móvel de 12 meses. Propōs o uso da média geométrí ca móvel para a obtenção de índices estacionais e concluiu que este método leva a resultados semelhantes ao do método que emprega a mé- 
dia aritmética móvel. Analisou a variaçāo estacional do milho no pe rlodo 1949/68, separando-o em trés sub-perfodos para a análise de resultados. Explicou as principais variaçöes nos Índices como conse quéncia da quantidade armazenada da safra anterior e da previsão da safra futura.

Obteve-se menor Índice, 63,1, em agosto de 1963, após as excepcionais safras de 1962 e 1963; o maior fndice obtido foi de 130,9, em dezembro de 1955, por causa da baixa produção do ano.

BRANDT (1969a) analisando séries temporais de preços agrícolas, observou que a persistência da flutuação dos preços não è um problema tão grave quanto o da amplitude atingida por elas, o que provoca desequilf́rios no consumo e comercialização dos produtos, resultando no uso não econômico dos recursos. Fez descrição dos principais estudos no Brasil sobre preços agrícolas e analisou os tipos de flutuaçöes de preços, apontando as causas dessas flutuaçōes.

HOFFMANN e CROCOMO (1972) estudaram a variação estacional dos preços dos produtos hortícolas no Estado de São Paulo,no período 1964/71, utilizando o método da média geométrica móvel. Tra balharam com preços correntes afirmando ser dispensável a operação de deflacionamento dos preços, uma vez que o processo de cálculo do Índice, com a determinação da média móvel, elimina as variaçães dos preços devidas à inflação. 
CARVALHO (1975), citado por WALDER (1976), estudando a variação estacional de preços de cereais no Estado de Espírito Santo, no período 1966/74, concluiu que o milho e o arroz apresenta ram nftidas variações estacionais de preços reais. 0 milho apresentou elevaçäo de preços de julho a janeiro e o arroz, de junho a dezembro. O feijāo nāo apresentou variaçōes estacionais de preços.

GARDNER (1975) analisou a diferença de preço de produtos entre a fazenda e o varejo num mercado competitivo. Utilizou-se de um modelo matemático com seis equaçōes básicas:

(a) Função de produção da indústria de comercializaçäo

$$
x=f(a, b)
$$

sendo $\underline{x}$ o produto final vendido no varejo; a bens agrícolas que entram na composição de $\underline{x}$; e $\underline{b}$ insumos de mercado.

(b) Demanda ao nível de varejo

$$
x=O\left(P_{x}, N\right)
$$

onde $P_{X} \vec{e}$ o preço do produto no varejo e $N$ uma variävel exögena da demanda, como a população.

(c) Pressupondo que as firmas de comercializaçäo compram quantidades de a e $\underline{b}$ visando à maximização de seus lucros, considera-se que o valor do produto marginal de cada insumo é igual ao preço do mesmo:

$$
\begin{aligned}
& P_{b}=P_{x} \cdot f b \\
& P_{a}=P_{x}=f a
\end{aligned}
$$


onde fa e fb são as derivadas parciais de $\underline{x}$ em relação a a e $\underline{b}$.

(d) Ofertas de insumos não agrícolas (de mercado) e do produto agrícola:

$$
\begin{aligned}
& P_{b}=g(b, T) \\
& P_{a}=h(a, w)
\end{aligned}
$$

As variáveis exógenas das ofertas dos insumos são re presentadas por $T$ e $W$. Por exemplo, W pode ser a variável clima e $T$ um imposto específico que incide sobre o insumo não agrícola.

Por meio de combinaçōes e diferenciação total das equaçöes, Gardner determina a elasticidade da razäo de preço varejo-produtor $\left(\mathrm{P}_{\mathrm{x}} / \mathrm{P}_{\mathrm{a}}\right)$ em função das variäveis exógenas da demanda do produto, ou da oferta dos insumos, supondo equilíbrio em mercados competitivos.

A elasticidade de $\left(P_{x} / P_{a}\right\}$ em função da populaçäo, por exemplo, para um produto especifico da agricultura, nos diz que se a demanda por alimento desloca-se para a direita e $e_{b}>e_{a}$ lelas ticidade dos insumos näo-agrícolas ë maior que a elasticidade do produto agrícola) a razão de preço ( $\left.P_{x} / P{ }_{a}\right)$ cai. Portanto espera-se o declínio da razão de preços quando a população aumenta,ceteris pa. ribus. A queda na razão de preços nos indica que ocorreu um declínio na margem de comercialização. Discute também o papel da elasticidade de substituição entre a e $\underline{\underline{a}}[\sigma]$. Se $\sigma \rightarrow \infty, P_{x} / P a$ e constante e se $\sigma \rightarrow 0$, o modelo Marshaliiano de demanda derivada pode ser apli cado. 
Na anälise da elasticidade da razão de preço $\left(P_{x} / P_{a}\right)$ em relação à variável clima (W), diz que normalmente é negativa se $0 \leq e_{\mathrm{b}}<\infty$. Portanto, um evento que aumente a oferta de $\underline{a}$, com queda de $\mathrm{Pa}$, aumentarä a diferença de preço entre $P_{x}$ e $P_{a}$. Analisando a elasticidade da razão de preço $\left(P_{x} / P_{a}\right)$ em função de um imposto $(T)$, conclui que é positiva em todos os casos normais. Se ocorrer um imposto sobre os insumos de mercado, acarretará um aumento em seu preço, o que levará a um aumento na diferença de preço entre $P_{\mathrm{x}} \& P_{\mathrm{a}}$

Gardner também aborda o problema de controle de pre ço. No primeiro caso discute o controle de preço do produto no varejo, por meio da elasticidade entre o preço do produto agrícola $\left(P_{a}\right)$ e o preço do produto no varejo $\left[P_{x}\right]$. A equação $(18)$ de seu trabalho è reproduzida a seguir

$$
E_{p_{a} \bar{p}_{x}}=\frac{\sigma+e_{b}}{\sigma+s_{a} e_{b}+s_{b} e_{a}}
$$

onde $\bar{p}_{x}$ ë o preço mäximo de venda no varejo; $S_{b}$ e $S_{a}$ são as porções relativas de $\underline{a}$ e $\underline{b}$ que são utilizadas.

Se $e_{a}=e_{b}$, sendo portanto $E_{p_{a} \bar{p}_{x}}=1$, uma reduçäocon trolada em $\mathrm{p}_{x}$ reduzirá $\mathrm{p}_{a}$ pela mesma porcentagem. Neste caso a margem percentual de mercado é constante. Se $e_{a}<e_{b}$, entäo $E_{p_{a}} \bar{p}_{x}>1$, e ocorrendo diminuição em $P_{x}$, o valor de $p_{a}$ cairá, aumentando a mar gem percentual. 
o sinal positivo da equação, implica que um preço te to efetivo no varejo sempre reduz o preço ao nível de fazenda. Analisando o caso de controle de preço ao nível de fazenda, obtem a elasticidade entre $P_{a}$ e $P_{x}$, quando $P_{a}$ é o preço su porte, o que é mostrado em sua equação (19):

$$
E_{p_{x} \bar{p}_{a}}=\frac{s_{a}\left(\sigma+e_{b}\right)}{e_{b}+s_{a} \sigma-s_{b} n}
$$

onde $\eta$ é a elasticidade preço da demanda para $\underline{x}$. Se $E_{p_{x} \bar{p}_{a}}$ for igual a 1, a margem percentual de mercado permanece constante. Coloca tam bém que se $e_{b}>n$, como nos casos normais, então $E_{p_{x}} \bar{p}_{a}$ será menor do que 1. Portanto, programas de controle de produçāo que aumentam $P_{a}$, podem aumentar $P_{x}$ por uma menor porcentagem, o que reduz a margem.

As equações (7) e (8) obtidas por Gardner são diferentes, e a elasticidade de transmissäo de preço, que representam não é independente do tipo de mudança exógena que gera modificação no preço - esta pode ser originária da demanda por $\underline{x}$ ou da oferta de a. Se a oferta de a é a fonte da variação do preço observado, en tão a equação (8) é relevante, e $E_{p_{x} \bar{p}_{a}} e^{e}$ menor do que I. Mas se são deslocamentos na demanda de alimentos que geram os preços observados, a equação (7) é a relevante.

Gardner diz também que o modelo utilizado por GEORGE e KING (1971) 1’', só é välido quando mudanças nos preços tiverem o1/ Este modelo è apresentado na parte referente à metodologia deste
trabalio. 
rigem ao nível da fazenda, isto é, quando ocorrerem mudanças na oferta. Esses autores usam a elasticidade de transmissão de preço fa ra derivar a elasticidade no nfvel da fazenda por meio da elasticidade preço da demanda do varejo, pela equação

$$
E_{a p_{a}}=(\eta) E_{p_{x} p_{a}}
$$

ocorre para a maioria dos produtos agrícolas.

De acordo com (9) se $E_{P_{x} P_{a}}<1$, então $E_{a p}<\eta$, como Gardner apresenta uma equação mais geral, proposta por Hicks, que mostra a relação entre a elasticidade de demanda de varejo, $n$, a a elasticidade de demanda ao nf́vel da fazenda. Esta é a equação

$$
E_{a p_{a}}=\frac{\eta \sigma+e_{b}\left(s_{a} \eta-s_{b} \sigma\right)}{e_{b}+s_{a} \sigma-s_{b} \eta}
$$

Se $E_{a p}$ è menor ou maior do que $n$, depende da relação entre $\sigma$ e do valor absoluto de $\Pi$. No caso de proporções fixas, desde que $\sigma=0, \sigma$ é sempre menor do que $|n|$ e neste caso a demanda ao nf́vel de fazenda é sempre menos elästica do que ao nfvel de vare jo.

Substituindo as equaçōes (8) e (10) na equação (9), Gardner mostra que a aproximaçäo geral da elasticidade de transmissão de preço utilizada por George e King só é välida quando $\sigma \rightarrow 0$. Portanto, o modelo de George e King só é välido quando o produto que sai da fazenda entra em proporção fixa na produção do produto final. 
19.

Aparentemente George e King fazem a pressuposição desnecessária de que $x \equiv a$, que é um caso particular da produção em proporções fixas. 


\section{HIPOTESES}

Neste capitulo procura- mostrar quais as princtpals hipöteses do trabalho.

Em estudos de comercializaçäa de produtos agrícolas é de interesse quantificar as parcelas do dispóndis do consumidor que vão ter aos intermediäriss e ao produtar. Também interessante é o acompanhamento da evolução dessas parcelas no decorrer do tempo. Relacionada a esses aspectos estä a questäo da varia çāo de preço nos diferentes nf́veis de comercialização. Isto pode ser analisado por meio da elasticidade de transmissäo de preço, que indica de quanto varia o preço no varejo por causa de uma variação no preço recebido pelo produtor.

A hipötese è que os aumentos näo sāo transmitidos in tegralmente de um nível para outro, isto é, a elasticidade de trans missāo de preço deve ser menor do que 1. Se ocorrer um aumento no 
preço recebido pelo produtor, este aumento näo será da mesma porcen tagem ao consumidor, porque o preço ao consumidor depende do preço do produto agrícola e dos insumos não-agrícolas usados na comercial1zação do mesmo. Em geral, na presença de competição de mercado $2 /$. com um aumento do preço ao produtor (redução da oferta), a quantida de demandada ca1, o que leva a uma queda na demanda de insumos não-agrícolas, cuja oferta geralmente é menos que perfeitamente elástí ca. Portanto ocorre uma queda em seu preço, o que leva a um aumento ao preço do consumidor; que é proporcionalmente menor do que o ocor rido no preço recebido pelo produtor. Teoricamente, a elasticidade de transmissão de preço será menor que a unidade sempre que $e_{b}>$ $>|\eta|$. 1sto é, em todos casos nomals (ver p. 17). Em particular,se $\sigma=0,0$ limite de $E_{p_{x} \bar{p}_{a}}$ quando $e_{b} \rightarrow \infty e ́:$

$$
e_{b}^{1+\infty} \frac{s_{a} e_{b}}{e_{b}-s_{b} \eta}=11 m \frac{s_{a}}{e_{b} \rightarrow \infty}=s_{a}
$$

1sto é, nesse caso a elasticidade de transmissão é 1gual à parcela de $\underline{a}$ em $\underline{x}$.

A hipötese de que os preços variam mais ao nível do produtor é uma decorrêncla lóglca do exposto acima. À medida que se caminha da safra para a entressafra, a quantidade colocada no merca do pelos produtores se reduz. Sendo a demanda ao nível de varejo

2/ Embora o modelo de Gardner permita considerar o pfeito de forças monopolísticas no mercado, esses efeitos não săo considerados na presente análise. 
mais elästica que a demanda ao nível do produtor, esperan-se maiores variaçōes de preço ao nível do produtor. Fatores como acesso ao crédito e facilidades de armazenamento poderiam contribuir para reduzir a disparidade entre as quantidades colocadas pelo produtor na safra e na entressafra e, consequentemente, para uma reduçäo nas va riaçōes de preços recebidos pelas produtores.

Na relaçäo entre armazenagem e preço, presume-se que o agricultor ou intermediärio retire ou adicione milho ao estoque, conforme o comportamento dos preços mensais do produto. Ao decidirem qual a quantidade a ser armazenada de um més para o seguinte,es pera-se que produtores e intermediários considerem a diferença entre o preço esperado no més seguinte e o preço presente.

Ao formar suas expectativas de preço, supöe-se que o agricultor ou comerciante considere os preços anteriores, bem como suas expectativas anteriores. Desse modo o preço num dado mès afeta (via formaçāo de expectativa) a variaçāo nos estoques mensais. Espera-se que um aumento no preço de um dado mês aumente o preço esperado no mês seguinte, mas reduza a diferença entre os dois valores. 


\section{METODOLOGIA}

\section{1 - Area de Estudo e Fonte de Dados}

A ärea de estudo deste trabalho ë a Estado de Säo Paulo. Os dados de preços do milho (no atacado a recebidos pelos produtores), como também os de armazenagem, foram obtidos da publicação mensal Informaçōes Econōmicas do Instituto de Economia Agríco la da Secretaria da Agricultura do Estado. Os preços são coletados por este órgão, enquanto os dados de armazenagem referem-se somente à Companhia de Entrepostos e Armazēns Gerais do Estado de São Paulo (CEAGESP).

Os preços do milho no varejo foram retirados da revista Inquérito Nacional de Preços, publicada pelo IBGE, que coleta aqueles preços quinzenalmente em diversas cidades do Estado. Estes dados são publicados em cruzeiros por quilo, os quais foram trans- 
formados em cruzeiros por saco de sessenta quilos para uniformizaçāo dos dados.

Os dados de produçāo säo do Instituto de Economia Agrícola, fornecidos por sua central de dados.

Nos cälculos de preços reais utilizou-se como deflator o "Indice $2^{n}$ da Fundação Getülio Vargas, com base no triênio $1965 / 67(=100)$.

As tabelas do Apêndice 1 contêm os dados de preços de milho nos três níveis de comercialização, como também os dados de armazenagem e de produçāo do Estado no perfodo 1965/76.

\section{2 - Margem de Comercialização}

A soma dos custos dos serviços de comercialização in corridos no encaminhamento da produçāo agrícola das zonas produtoras até os consumidores, mais os lucros dos agentes intermediärios, é definida como margem de comercialização.

Segundo BRANDT (1969a) "a margem de comercialização e, por conseguinte, do produtor, em geral, parece variar entre os produtos e depende de fatores tais como: a) estacionalidade da produção; b) relaçāo peso/volume do produto; c) manufaturação exigida: d) variação nos preços dos fatores (insumos) usados na comercializa ção: e) mudanças tecnolögicas nas operaçōes comerciais; e f) mudança na estrutura de mercado". 


\subsection{1 - Determinação das Margens}

A margem absoluta de comercialização é a diferença entre os preços pagos pelos consumidores e os preços recebidos pelos produtores. Por margem de atacado e de varejo, entende-se a diferença entre os preços pagos e recebidos pelos referidos comercian tes.

As seguintes fórmulas matemäticas são utilizadas para o cálculo de margens.

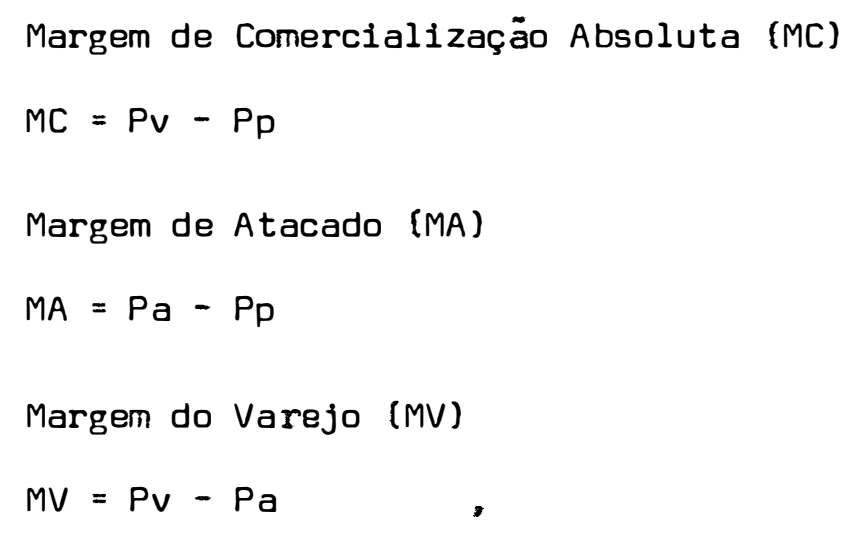

onde: $\mathrm{Pp}=$ preço ao $\mathrm{n}$ f́vel de produtor, isto é, o preço que o produtor recebeu pelo produto;

$\mathrm{Pa}=$ preço ao nível de atacado, ou preço pago pelo varefista;

Pv = preço ao nf́vel de varejo, ou preço pago pelo consumidor.

A margem absoluta engloba todos os custos e lucros da comercialização, e é tambèn a soma das margens de atacado e de varejo.

Para cälculo das margens percentuais, utilizam-se as seguintes förmulas. 
Margem de Comercialização Percentual (MCP)

$$
M C P=\frac{P v-P p}{P v} \cdot 100
$$

Margem Percentual do Produtor (MPP)

$$
M P P=\frac{P p}{P v} \cdot 100
$$

Margem Percentual do Atacado (MPA)

$$
M P A=\frac{P_{a}-P_{p}}{P_{v}} \cdot 100
$$

Margem Percentual do Varejo (MPV)

$$
M P V=\frac{P v-P a}{P V} \cdot 100
$$

A margem percentual do produtor indica a sua partici paçäo no preço final do produto; a margem percentual do atacado indica a participação do atacadista no preço final e a margem percentual do varejo indica a participação do varejista no preço que rece beu. A margem de comercializaçäo percentual é a soma das margens per centuais do atacadista e do varefista, indicando portanto, a parcela que foi adicionada depois da venda do produto pelo produtor.

Em muitos trabalhos aparece o cálculo de "markup" , sendo que este, em termos absolutos, tanto no atacado como no varejo, é igual à margem de comercialização correspondente.

Em termos percentuais pode ser calculado pelas seguintes förmulas. 
"Markup" do Atacado (KA)

$$
K A=\frac{P v-P p}{} \cdot 100
$$

Pp

"Markup" do Varejo (KV)

$$
K V=\frac{P V-P a}{P a} \cdot 100
$$

0 "markup" é a porcentagem de ganho em relação ao pre ço de compra. Geralmente o "markup" é tomado como indicador de eficiêncula do sistema de comercialização.

\subsection{2 - Fatores que afetam as margens de comercialização}

Ao se fazer um estudo de Margens de Comercialização, seria interessante considerar a totalidade dos serviços prestados pelos agentes de comercialização. No entanto, constatou-se que as informaçōes a respeito dos preços de produtos derivados do milho no varejo são limitadas. Decidiu-se então não considerar a fase de prọ cessamento no cálculo das margens no presente estudo. Os resultados aqui obtidos, todavia, são välidos para o montante total de milho comercializado no Estado. Assim, o preço de varejo utilizado é visto como equivalente ao preço de toda produção de milho àquele nível, excluído o processamento. Este argumento é válido sob a hipótese de competição no mercado, pois nessa situação, o preço do milho "in na tura" seria igual ao valor do milho utilizado na produção de produtos processados. Isto é, sob condições de competição perfeita deveria ser indiferente ao comerciante vender o produto "in natura" ou transformado. 
Dutro fator que influencia as margens de comercializaçāo è a perecibilıdade dos produtos agrícolas. Em garal, quanto maior a perecibilidade do produto, maior serà sua margem de comercialização. Isto ocorre por causa de maiores perdas ou devido aos maiores cuidados que esse produto deve recober durante a comerciali zaçāo.

Sabe-se que muitos produtos sofrem classificação para venda, o que envolve um custo. Em geral, a classificação é feita após a safda do produto da propriedade agrícola, portanto, após uma reunião de grande parcela da produção.

As margens são também afetadas pelos métodos de comercializaçäo, e pelos preços dos insumos que entram no processo. Por exemplo, o aumento do preço da gasolina pode levar a um aumento da margem de comercialização dos produtos na medida que eleva os custos de transporte.

\subsection{3 - Limi tações no cälculo de margens}

As limitaçōes säo em sua maioria relacionadas com as séries de preços que são utilizadas no trabalho.

A determinação do preço de varejo, pelo qual foi ven dido um produto especffico, é muito diffcil, principalmente quando se agrega o Estado todo. Isto se dá por causa do maior número de agentes atuando nesse nível de comercialização.

Quando o produto sofre transformaçāo, produz-se si- 
multaneamente sub-produtos de valor económico. Tais sub-produtos de veriam ser considerados no cälculo de margem. No caso do milho, que ë comercializado quase sem traneformaçāo, esse problema é menor.

Quando se utilizam dados de diferentes fontes,os pro cessos de coleta dos dados não são uniformes. Assim a validade estatística dos resultados fica limitada. A impossibilidade de um pro cedimento mais adequado obriga, no entanto, à utilização de dados dessa natureza.

Outra limitação decorre do fato de que os preços levantados nos diferentes níveis referem-se a um mesmo período. Assim a margem não considera adequadamente os custos de transferéncia do produto no tempo, por meio de armazenagen.

\section{3 - Anälise Economètrica das Políticas de Margem de Comerciali zaçäo}

Encontram-se poucos trabalhos no Brasil sobre o assunto. BRANDT (1969b), analisou 9 produtos no Estado de Säo Paulo e CARMO (1969) analisou a margem de comercializaçāo da carne bovina no Estado, ambos utilizando o mesmo método. HOFFMANN (1969b) introduziu algumas variaçōes no método em seu trabalho sobre a anälise da margem de comercializaçāo de ovos no Estado.

A anälise da política de margem de comercializaçäo nos diferentes níveis, é feita através da relaçäo funcional entre o preço no varejo (ou no atacado) no més $t$ e o preço no atacado (ou 
pago ao produtor) no més $t$, por meio da equaçäo:

$$
y_{t}=\alpha+\beta x_{t} \quad ; t=1,2, \ldots, T
$$

onde, $Y_{t}=$ preço no varejo (ou no atacado) no més $t$;

$\alpha=$ poränetro. Coeficiente Iinear da reta. Esse componente de Y corresponde aos custos e tributos fixos, em cruzeiros que oneram a comercialização;

$\beta=$ paràmetra. Coeficiente angular da reta. Dá indicação de quanto o comerciante aplica porcentualmente sobre o preço do produto:

$x_{t}=$ preço ao nível de atacado (ou ao produtor) no més $t$.

Emprega-se o método dos mf́nimos quadrados para estimar os parämetros $\alpha$ e $\beta$ das funçöes referentes a perfodos de 12 meses.

Para a determinação da polftica de margens de comercializaçäo, testa-se inicialmente a hipötese de que $\alpha=0$. Se $\alpha>0$, indica a existència de um elemento fixo na margem. Depois testam-se as hipöteses de que $\beta=0$ e $\beta=1$. Se for verificado que $0<\beta<1$, tem-se uma indicação de que existe um elemento variável na composição das margens. Os testes bilaterais foram realizados ao nível de $10 \%$

Os quatro tipos de margem que podem ocorrer, segundo BRANDT estão na tabela 1 . 
Tabela 1 - Tipos de Polfticas de Margem.

\begin{tabular}{llll}
\hline Tipo & $\alpha$ & $B$ & Denominaçäo \\
\hline I & $=0$ & $=1$ & $\begin{array}{l}\text { Preço de compra igual ao preço de } \\
\text { venda. }\end{array}$ \\
II & $>0$ & $=1$ & $\begin{array}{l}\text { Polftica de margem fixa, em termos } \\
\text { monetórios. }\end{array}$ \\
III & $=0$ & $>1$ & Polftica de margem percentual fixa. \\
IV & $>0$ & $>0$ & Polftica de margem mista.
\end{tabular}

BRANDT (1969b) coloca ainda que "espera-se que os coeficientes de determinação sefam relativamente elevados. Isto se explica pelo simples fato de o preço de atacado ser componente do preço do varejo e de o preço pago aos produtores agrícolas ser componente do preço de atacado".

MOFFMANN (1969b) analisando este parágrafo, diz que esse ë um caso de "correlaçäo espüria" que pode ser facilmente evitado, fazendo a regressāo do "markup" (e nāo o "preço de venda") em relaçäo ao "preço de compra".

A seguir transcrevemos os métodos estatísticos, empregados por HOFFMANN e que seräo utilizados no presente trabal ho. O modelo estatf́stico utilizado na análise é o seguinte:

$$
M_{i}=\alpha+\beta P_{i}+E_{i} \quad, \quad(i=1,2 \ldots, 12)
$$


onde, $M_{1}=$ margem de comercializaçäo no mês $\underline{1}$;

$\alpha$ e $\beta=$ parámetros;

$P_{1}=$ preço pago ao produtor;

$E_{1}=$ erro aleatörio.

Faz-se uma regressão para cada ano, sendo os preços en valores reais, en cruzejros de 1965/67.

Na análise da margem de comercializaçäo no atacado. a variävel dependente passa a ser MA a ne anälise de margem de comercializaçāo no varejo, a variável dependente passa a ser MV e a variável independente passa a ser o preço no atacado.

0 teste $\underline{t}$ foi utilizado para testar as hipóteses da nulidade de $\alpha=0$ e $\beta=0$. Foi feito um teste bilateral, sendo $10 \%$ o nivel de significància máximo considerado. Conforme o resultado dos testes, pode-se chegar a uma caracterizaçāo da política de "mar kup" vigente no ano, de acordo com o que se acha esquematizado na tabela 2. 
Tabela 2 - Caracterização da política de "markup" em função do sinal da estimativa e de resultado do teste $t$ para os parämetros $\alpha$ e $\beta$.

\begin{tabular}{|c|c|c|c|}
\hline $\begin{array}{l}\text { Sinal da esti } \\
\text { mativa e tes- } \\
\text { te } \underline{t} \text { para } \alpha\end{array}$ & $\begin{array}{l}\text { Sinal da esti } \\
\text { mativa e tes- } \\
\text { te } \underline{t} \text { para } B\end{array}$ & $\begin{array}{l}\text { Caracterização } \\
\text { da política } \\
\text { de "markup" }\end{array}$ & $\begin{array}{l}\text { Sim- } \\
\text { bolo }\end{array}$ \\
\hline $\begin{array}{c}\text { não } \\
\text { significativo }\end{array}$ & $\begin{array}{c}\hat{B}>0 \\
\text { significativo }\end{array}$ & $\begin{array}{l}\text { Margem absoluta crescente. } \\
\text { Näo se pode rejeitar a hi- } \\
\text { pötese de que o "markup" } \\
\text { relativo é constante. }\end{array}$ & $R$ \\
\hline $\begin{array}{c}\hat{\alpha}>0 \\
\text { significativo }\end{array}$ & $\begin{array}{c}\text { não } \\
\text { significativo }\end{array}$ & $\begin{array}{l}\text { Não se pode rejeitar a hi- } \\
\text { pótese de que a margem ab- } \\
\text { soluta é constante. O "mar } \\
\text { kup" relativo é decrescen- } \\
\text { te. }\end{array}$ & $F$ \\
\hline $\begin{array}{c}\tilde{\alpha}>0 \\
\text { significativo }\end{array}$ & $\begin{array}{c}\hat{B}>0 \\
\text { significativo }\end{array}$ & $\begin{array}{l}\text { Margem absoluta crescente } \\
\text { e "markup" relativo de- } \\
\text { crescente. }\end{array}$ & $E$ \\
\hline $\begin{array}{c}\hat{\alpha}>0 \\
\text { significativo }\end{array}$ & $\begin{array}{c}\hat{\beta}<0 \\
\text { significativo }\end{array}$ & $\begin{array}{l}\text { Margem absoluta e "markup" } \\
\text { relativo decrescentes. }\end{array}$ & $D$ \\
\hline $\begin{array}{c}\bar{\alpha}<0 \\
\text { significativo }\end{array}$ & $\begin{array}{c}\bar{B}>0 \\
\text { significativo }\end{array}$ & $\begin{array}{l}\text { Margem absoluta e "markup" } \\
\text { relativo crescentes. }\end{array}$ & C \\
\hline $\begin{array}{c}\text { näo } \\
\text { significativo }\end{array}$ & $\begin{array}{c}\text { näo } \\
\text { significativo }\end{array}$ & Indetermi nada & $I$ \\
\hline
\end{tabular}

Do exposto, verifica-se que a principal diferença dos dois modelos estä no uso de preço como variável dependente por BRANDT e margem de comercialização por HOFFMANN. 


\section{4 - Elasticidade de Transmissão de Preço}

Este é um conceito utilizado por GEORGE E KING(1971), e faz-se aqui uma tentativa de introduzir este conceito na presente análise.

Em relação à margem de comercializaçãa ahsaluta, a elasticidade de transmissão de preço é a razão entre a varlação relatıva no preço de varejo para uma variação relativa no preço ao ní vel da fazenda.

Matematicamente podemos escrever este conceito de elasticidade como

$$
\varepsilon=\frac{\partial P_{v}}{\partial P_{p}} \frac{P_{P}}{P_{v}}
$$

Considerando-se a margem de comercialização absoluta para o desenvolvimento a seguir, pode-se escrever:

$$
\begin{aligned}
& M C=\alpha+\beta_{p} P_{p} \\
& P_{v}=P_{p}+M C
\end{aligned}
$$

Substituindo (I) em (II):

$$
\begin{aligned}
& P_{v}=P_{p}+\alpha+\beta_{1} P_{p} \\
& P_{v}=\alpha+\left(1+\beta_{1}\right) P_{p}
\end{aligned}
$$

Derivando $P_{V}$ em relação a $P_{P}$, obtemos

$$
\frac{\partial P_{V}}{\partial P_{p}}=1+B_{1}
$$


Multiplicando os dois termos por $P_{p} / P_{v}$, teremos que

$$
\frac{\partial P_{v}}{\partial P_{p}} \frac{P_{p}}{P_{v}}=\left(1+B_{1}\right) \frac{P_{p}}{P_{v}}=\varepsilon \text {, }
$$

que ë a fórmula de elasticidade de tranomissão de preço.

A elasticidade de transmissão de preço $(\varepsilon)$ dá a informação de como o preço no varejo varia em relação a uma variação no preço ao nível de produtor.

Pode-se também calcular a elasticidade de transmissão de preço para o atacadista $\left(\varepsilon_{A}\right)$ e o varejista $\left(\varepsilon_{V}\right)$.

Sendo a análise econométrica da margem de atacado feita com base na seguinte equação $M A=\alpha+\beta_{2} P_{p}$, e como $M A=P_{a}$ $-P_{p}$, tem-se que $P_{a}=\alpha+\left(1+\beta_{2}\right) P_{p}, e$

$$
\varepsilon_{A}=\frac{\partial P_{A}}{\partial P_{P}} \frac{P_{P}}{P_{A}}=\left(1+B_{2}\right) \frac{P_{P}}{P_{A}} \text {, }
$$

que indica como varia o preço no atacado em função de uma variação no preço do produtor.

Em relação ao varejo, partindo da equação $M V=\alpha+$ $+B_{3} P_{a}$ e $M V=P_{V}-P_{a}$, tem-se que $P_{v}=\alpha+\left(1+B_{3}\right) P_{a} e$

$$
\varepsilon_{V}=\frac{\partial P_{V}}{\partial P_{A}} \frac{P_{A}}{P_{V}}=\left(1+\beta_{3}\right) \frac{P_{A}}{P_{V}} .
$$

Esta elasticidade indica como o preço no varejo varía em relação a uma variação no preço do atacado. 
De acordo com hipótese formulada no capítulo anterior (p. 20), espera-se que a elasticidade de transmissão de preço seja menor do que 1 (um), significando que as variaçöes percentuais no preço de compra não são totalmente transferidas aos preços de venda. Quando a elasticidade é igual a l (um) todas as variações per centuais nos preços de compra são transmitidas aos preços de venda e quando a elasticidade de transmissão é igual a 0 (zero) não ocorre nenhuma transmissão da variação percentual do preço de compra pa ra o preço de venda.

\section{5 - Variação Estacional}

SPIEGEL (1972) relaciona quatro métodos de cálculo de Índices estacionais de uma série de preços mensais: a) média das percentagens dos preços mensais em relação ao preço médio anual; b) média das percentagens dos preços mensais em relação ao valor da tendência ajustada; c) método da média aritmética móvel centralizada, e d) método que utiliza os valores percentuais do preço de um mês em relação ao mês anterior.

LANGE (1967) demonstra que "as flutuações periódicas de uma série temporal podem ser eliminadas por meio de uma média mó. vel de número de termos igual ao período de flutuação da série ou a um mültiplo desse período".

HOFFMANN (1969a) discute os métodos de cálculo da mé dia aritmética móvel centralizada e do cálculo de média geométrica 
móvel centralizada, utilizando-se de preços correntes e deflacionados nesses cálculos. Conclui que "os dois métodos levam a Indices de variação estacional semelhantes". Em relação ao uso de preços correntes ou deflacionados, diz que é dispensável o deflacionamentopré vio dos preços.

\subsection{1 - Fundamentos para cālculo da variação estacional}

Pode-se considerar numa série cronológica de preços

$\left(P_{1}\right)$ a existência de quatro componentes: (a). tendência secular $\left(O_{1}\right)$; (b) variações estacionais. $\left(S_{1}\right)$; (c) variações cf́clicas. $\left(C_{i}\right)$ e (d) variações irregulares, $\left(R_{1}\right)$.

Os valores de uma série de preços no tempo podem ser considerados como resultado do produto desses componentes, uma vez que, no caso de produtos agrícolas, apresentam variações relativas mais ou menos constantes.

Admite-se que a variável $P_{i}$ da série temporal é um produto das variáveis $D_{i}, S_{i}, C_{1}$ e $R_{1}$, que produzem, respectivamente os movimentos de tendência secular, variações estacionais, varia ções cĺclicas e variações irregulares.

$$
P_{i}=D_{i} \cdot S_{i} \cdot C_{i} \cdot R_{i} \text {, onde } P_{i} \text { é o preço médio no }
$$
período (mês) 1 . 0 uso do produto implica que a variação relativa em $P_{i}$ é igual à soma das variações relativas dos componentes.

A anälise das séries temporais consiste em uma inves tigação dos fatores $D_{1}, S_{1}, C_{1}$ e $R_{1}$, e é frequentemente classifica- 
da como decomposição. Dever-se-ia mencionar que alguns estatisticos preferem considerar $P_{1}$ como soma destes mesmos componentes.

0 problema estatistico da determinação do f́ndice de variação estacional consiste em 1 solar o componente $S_{1}$.

As variações estacionais resultam das variações climáticas ou dos costumes sociais que na maioria dos casos estão associados as variações climáticas. O fato de as variações estacionais dos preços serem devidas a causas independentes, sem relação com as outras variações e tendênclas apresentadas pelos mesmos preços, facilita o isolamento do componente estacional.

A determinação dos fndices de variação estacional de preços ë facilitada também pelo fato de tratar-se de flutuações aproximadamente periódicas.

Para determinação da variação estacional é necessärio isolar da série de preços a tendēncia $\left(D_{1}\right)$ e as variações cíclí cas $\left(C_{1}\right)$, respectivamente, cabendo ressaltar que ambas são bastante interrelacionadas e, portanto de diff́cil separação.

Com a finalidade de eliminar as flutuações periódicas das séries temporais, utilizar-se-á do processo da média geométrica móvel centralizada de 12 meses.

A partir dos termos da série dos preços mensais $P_{1}$ (com $1=1,2,3, \ldots, n$, onde $n$ é o nümero de termos contidos na série de preços) calculou-se a média geométrica móvel centralizada para o mês em questão, utilizando-se da seguinte expressão: 


$$
\bar{P}_{1}=\sqrt[12]{\left(P_{1-6}\right)^{0,5}\left(P_{1-5}\right) \ldots P_{i} \ldots\left(P_{i+5}\right)\left(P_{1+6}\right)^{0,5}}
$$

onde $\underline{1}$ é o mês no qual se centraliza a média geométrica.

A mesma expressão pode ser apresentada na forma logarítimica

$$
\log \bar{P}_{1}=\frac{0,5 \log P_{1-6}+\log P_{1-5}+\ldots+\log P_{1}+\ldots+0,5 \log P_{1+6}}{12}
$$

A nova série obtida $\left(\bar{P}_{1}\right)$ é uma série suavizada ou corrigida, sendo $1=7,8, \ldots, n-6$.

Os valores do índice estacional de preços $\left(I_{1}\right)$ foram estimados pelo quociente entre os preços $\left(P_{1}\right)$ e as respectivas médias geométricas centralizadas $\left(\bar{P}_{1}\right)$ multiplicado por 100.

$$
\hat{\mathrm{I}}_{1}=\frac{\mathrm{P}_{1}}{\bar{P}_{i}} 100 \text {. }
$$

Esses valores do índice estacional compuseram uma no va série, onde cada elemento $\left(\overline{\mathrm{I}}_{1}\right)$ é a estimativa da variação estacional de preços, mais uma parte da variação irregular.

$$
\text { Ao se eliminar do indice estacional }\left(\hat{I}_{1}\right) \text { a estimati- }
$$
va das flutuações irregulares $\left(\tilde{R}_{1}\right)$ chegou-se ao índice estacional puro $\left(\hat{z}_{1}\right)$. Para tanto, calculou-se a média geométrica dos índices estacionais para cada mès, utilizando-se a expressão

$$
\bar{I}_{h}=\sqrt[m]{\prod_{j=1}^{m} \hat{I}_{i j}}
$$


onde $f=1,2, \ldots, m$ indica ano; $h=1,2,3, \ldots, 12$ indica mês dentro do ano: $m$ é o númera de anos completos na série dos $\hat{\mathrm{I}}_{\mathcal{I}}$.

Se a média geométrica dessas médias não for aproxima damente igual a 100, elas deverão ser ajustadas pelo fator de correção (F) dado pelo quociente de 100 pela média geométrica das 12 médias dos Indices estacionais, cuja expressão matemätica é:

$$
F=\frac{100}{\sqrt[12]{\prod_{i=1}^{12} \overline{\bar{I}}_{h}}}
$$

0 Indice estacional corrigido $\left(\hat{z}_{1}\right)$ para os 12 meses do ano foi determinado pelo produto de:

$$
\bar{z}_{1}=\overline{\bar{I}}_{h} \cdot F
$$

onde $i=1,2, \ldots, 12$.

0 Indice de irregularidade $\left(\bar{R}_{1}\right)$ foi estimado a partir do erro padrão dos logarítmos dos valores do fndice estacional em torno da sua média.

Para Janeiro, por exemplo, ter-se-ia:

$$
s_{j a n}=\sqrt{\frac{\sum\left(\log I_{j a n}-\log \bar{I}_{j a n}\right)^{2}}{n-1}} .
$$

0 antilogaritmo do erro padrão forneceu os valores estimados do Indice de irregularidade $\left(\hat{R}_{i}\right)$, os quais constituiramuma série de 12 termos. 
Os limites de um intervalo indicativo do grau de dis persäa do Indice estacional foram estabelecidos da seguinte forma: (a) o limite superior, pelo produto das termos correspondentes de $\hat{Z}_{1}$ e $\hat{R}_{1}$; e o limite inferior, pelo quociente dos termos correspondentes de $\hat{z}_{1}$ e $\hat{R}_{1}$. Portanto

$$
\begin{aligned}
& \text { limite superior }=\hat{z}_{1} \cdot \hat{R}_{1} \\
& \text { limite inferior }=\hat{z}_{1} / \hat{R}_{1} .
\end{aligned}
$$

Esses foram os elementos necessários para a determinaçäo da variação estacional dos preços. Em seguida inclui-se análi se de variància, com a finalidade de testar a significància estatís tica da variação estacional dos preços.

$$
\text { Considerando-se o modelo } P_{1}=D_{1} \cdot S_{1} \cdot R_{1} \text { pode-se }
$$
analisar, apenas, a variància dos logarítmos dos fndices estaciona1s. Isto porque, no modelo exposto, sem logaritmos, não é satisfeita uma exigência básica do modelo matemático da análise de variância, ou seja, aquela de que o efeito testado e o erro se adicionam a média geral (ver PIMENTEL GOMES, 1976, p. 24).

$$
\text { Aplicando-se logarítmos à expressão acima citada, }
$$

obtemos

$$
\log P_{i}=\log D_{1}+\log S_{1}+\log R_{i}=
$$

Admitindo-se que o valor da tendência $\left(D_{1}\right)$ seja eliminado ao se dividir o preço pela média geométrica móvel correspondente, o logaritmo do Indice estacional é 


$$
\log P_{i}=\log S_{1}+\log R_{1}
$$

A anälise de variância poderá agora ser efetuada, ad mitindo-se que o logarítmo de $R_{1}$ tenha distribuição aproximadamente normal. O valor de $F$ para os meses indicará se os Indices dos produ tos estudados são diferentes entre si, para os 12 meses do ano.

\section{6 - Armazenagem}

Pretende-se, por limitação de dados, analisar o sistema de armazenagem do milho na Companhia de Entrepostos e Armazéns Gerais do Estado de São Paulo (CEAGESP).

$$
\text { Será feita uma análise das quantidades armazenadas }
$$

anualmente, considerando seus valores minimos, médios e máximos,com parados com a capacidade total utilizável. Esta foi tomada no fim do ano, o que não é sempre real por ocorrerem novas instalações no periodo de um ano.

Depois será comparada a quantidade armazenada, ainda considerando os valores mínimos, médios e máximos, com a produção do Estado. Por fim será analizado o crescimento da produção, da capaci dade de armazenagem e da quantidade máxima armazenada no perfodo da pesquisa.

Quanto à análise do comportamento da demanda de arma zenagem, espera-se que variações nos preços determinem variações nos estoques de milho no CEAGESP. 
Será utilizado um modelo dinâmico de expectativa de preço, no qual pode-se analisar as variações de estoque, tanto no curto prazo (com respeito ao preço do mês), como no longo prazo (com respeito à expectativa no mès seguinte).

\subsection{1 - Mode lo da demanda de armazenagem}

0 modelo a ser utilizado ë o seguinte:

$$
\Delta Q=f(\Delta P)
$$

isto é, a variação de estoque é função da variação do preço, sendo a função básica utilizada a seguinte

$$
\frac{Q_{t}}{Q_{t-1}}=\alpha\left(\frac{P_{t+1}^{*}}{P_{t}}\right)^{\beta} \varepsilon_{t}
$$

onde, $Q_{t}=$ quantidade armazenada no final do mês $t$;

$Q_{t-1}=$ quantidade armazenada no final do mês $t-1$;

$P_{t+1}^{*}=$ preço esperado no mês $t+1$;

$\alpha$ e $\beta=$ parâmetros;

$\varepsilon_{t}=$ erro aleatório.

Como o preço $P_{t+1}^{*}$ não pode ser observado, faz-se uma pressuposição acerca de como ele se forma a partir de preços pas sados. No presente caso, a pressuposição é a de que os produtores e 
intermediários corrigem mensalmente suas expectativas numa proporção do erro nas suas expectativas no mès anterior.

Isso pode ser representado por uma expressão que tem a seguinte forma:

$$
P_{t+1}^{*}-P_{t}^{*}=(1-\lambda)\left(P_{t}-P_{t}^{*}\right) \quad, 0 \leq \lambda<1
$$

como aparece em KMENTA (1971, p. 475).

Mas é conveniente pressupor que as equaçöes (11) e (12) sejam lineares nos logarítmos das variáveis, de modo que a expressão (12) é substitulda por:

$$
\frac{P_{t+1}^{*}}{P_{t}^{*}}=\frac{P_{t}}{P_{t}^{*}}(1-\lambda)
$$

Tomando os logarítmos da expressão (13), obtem-se

$$
(1-\lambda)=\frac{\ln P_{t+1}^{*}-\ln P_{t}^{*}}{\ln P_{t}-\ln P_{t}^{*}}
$$

Neste caso $(1-\lambda)$ será a elasticidade de expectativa de preço, como mostra NERLOVE (1971), e onde,

$$
\begin{aligned}
P_{t+1}^{*} & =\text { preço esperado no mês } t+1 ; \\
P_{t}^{*} & =\text { preço esperado no mès } t ; \\
P_{t} & =\text { preço observado no mês } t .
\end{aligned}
$$

Da equação (14) pode-se obter:

$$
\ln P_{t+1}^{*}-\lambda \ln P_{t}^{*}=(1-\lambda) \ln P_{t}
$$

Aplicando logarítmo à equação (11), tem-se: 


$$
\left(\ln Q_{t}-\ln Q_{t-1}\right)=\ln \alpha+\beta\left(\ln P_{t+1}^{*}-\ln P_{t}\right)+\ln \varepsilon_{t}
$$

Defasando (16) de um perfodo e multiplicando por $\lambda$ re

sulta

$$
\lambda\left(\ln Q_{t-1}-\ln Q_{t-2}\right)=\lambda \ln \alpha+\beta \lambda\left(\ln P_{t}^{*}-\ln P_{t-1}\right)+\lambda \ln \varepsilon_{t-1}
$$

Subtraindo a equação (17) da equação (16), passando $\lambda\left(\ln Q_{t-1}-\ln Q_{t-2}\right)$ para o segundo membro e colocando $\ln \alpha$ em evidência, e fazendo reafustes posteriores obtem-se

$$
\begin{aligned}
\left(\ell n Q_{t}-\ln Q_{t-1}\right)= & (1-\lambda) \ln \alpha+\beta\left(\ell n P_{t+1}^{*}-\lambda \ell n P_{t}^{*}\right)-\beta \ell n P_{t}+ \\
& +\lambda \beta \ell n P_{t-1}+\lambda\left(\ell n Q_{t-1}-\ell n Q_{t-2}\right)+\ell n \varepsilon_{t}- \\
& -\lambda \ell n \varepsilon_{t-1} .
\end{aligned}
$$

Substituindo $\ell n P_{t+1}^{*}-\lambda \ell n P_{t}^{*}$ pelo obtido na expres são (15) e fazendo as simplificaçōes necessärias, tem-se:

$$
\begin{aligned}
\ln Q_{t}-\ln Q_{t-1}= & (1-\lambda) \ln \alpha-\lambda B\left(\ln P_{t}-\ln P_{t-1}\right)+\lambda\left(\ln Q_{t-1}-\right. \\
& \left.-\ln Q_{t-2}\right)+\gamma_{t}
\end{aligned}
$$

onde $\gamma_{t}=\ell n \varepsilon_{t}-\lambda \ell n \varepsilon_{t-1}$.

Alternativamente poder-se-ia pressupor que os erros na forma logarítmica não são independentes. Assim poder-se-ia expressá-los da seguinte forma:

$$
\ln \varepsilon_{t}=\rho \ln \varepsilon_{t-1}+\ln u_{t}
$$

$\operatorname{com} E\left(\ell n \varepsilon_{t-1} \ln u_{t}\right)=0$ e os $\ell n u_{t}$ independentes e normalmente dis tribuidos. 
Nesse caso, o erro na expressão (18) passa a ser:

$$
\begin{aligned}
& \gamma_{t}=\rho \ln \varepsilon_{t-1}+\ln u_{t}-\lambda \ln \varepsilon_{t-1} \\
& \gamma_{t}=(\rho-\lambda) \ln \varepsilon_{t-1}+\ln u_{t}
\end{aligned}
$$

Dessa maneira poder-se-ia ter o caso de o coeficiente de ( $\ell n Q_{t-1}-\ln Q_{t-2}$ ) em (18) ser significativo e ao mesmo tempo os erros $\gamma$ não serem autoregressivos. Isto ocorreria se $\rho$ não dí ferisse de $\lambda$. Um teste assintótico dessa possibilidade é apresentado no capitulo seguinte (ver teste Durbin).

A equação (18) é a forma reduzida que serā utilizada para o ajustamento empirico da demanda.

Da expressão (14) pode-se observar que se $\lambda=1$, 0 preço esperado no mês seguinte será igual ao preço esperado no mês corrente. Se $\lambda=0$, o preço no mês seguinte será igual ao preço obtido no mês corrente.

\subsection{2 - Estimação e teste do modelo}

O ajustamento será feito por meio do método de mínimos quadrados ordinários.

Será feita análise estatística pelo teste "t" e F pe 10 menos ao nível de $10 \%$ de probabilidade.

Com a finalidade de testar a hipótese da ausência de correlação serial nos resf́duos calculados, será utilizado o teste conhecido como estatística "d" de Durbin-Watson. Com esta estatísti 
ca, será feito o teste de Durbin, calculando "h" como apresentado por JOHNSTON (1972).

A função a estimar será:

$\ln Q_{t}-\ln Q_{t-1}=a-b\left(\ln P_{t}-\ln P_{t-1}\right)+\lambda\left(\ln Q_{t-1}-\ln Q_{t-2}\right)+\gamma$ onde $a=(1-\hat{\lambda})$ ln $\hat{\alpha}$ e $b=\hat{\lambda} \bar{\beta}$.

Para se voltar à equação original (11), calcula-se

$$
\hat{\alpha}=e^{a /(1-\bar{\lambda})} \quad \text { e } \quad \hat{B}=\frac{b}{\hat{\lambda}} \text {. }
$$

A elasticidade de expectativa de preço é dada por

$$
E=(1-\hat{\lambda}) .
$$

Na forma reduzida estimada temos a elasticidade preço de curto prazo (com respeito ao preço do mês), que nos é dada pelo parämetro estimado para a variável preço, $\underline{\text { b. }}$

A elasticidade de longo prazo (com respeito ao preço esperado no mès seguinte) é dada pelo coeficiente estimado da equação original, isto é, o valor de $\bar{\beta}$. 
48.

\section{RESULTADOS E DISCUSSÃO}

Esta parte do trabalho seguirá os mesmos sub-ftens utilizados no capitulo 4.

\section{1 - Margem de Comercialização}

Observando os dados da tabela 3 e a figura 1 , verifi ca-se que, no período 1965/75, a margem do varejista é, conforme o més 2,3 a 3 vezes malor que a margem do atacadista. A margem do ata cadista oscila entre os valores $10,68 \%$ a $16,94 \%$ e do varej1sta osc1 la entre os valores $25,66 \%$ e $36,59 \%$.

A média mensal da margem de comercialização no perfodo estudado não atı́ngiu em nenhum més a marca de $50 \%$. Portanto, o produtor sempre recebeu, em média, mals do que a metade do valor pago pelo consumidor. 
Tabela 3 - Médias mensais da margem do atacadista, da margem do varejista e da margem de comercialização, em porcentagem do preço do milho no varejo, no Estado de São Paulo, período $1965 / 75$.

\begin{tabular}{lccc}
\hline M é s & $\begin{array}{c}\text { Margem do } \\
\text { Atacado } \\
\%\end{array}$ & $\begin{array}{c}\text { Margem do } \\
\text { Varejo } \\
\%\end{array}$ & $\begin{array}{c}\text { Margem de } \\
\text { Comercialização } \\
\%\end{array}$ \\
\hline janeiro & 11,97 & 25,66 & 37,63 \\
fevereiro & 10,68 & 29,86 & 40,54 \\
março & 11,56 & 33,87 & 45,43 \\
abril & 12,23 & 36,59 & 48,82 \\
maio & 14,07 & 35,25 & 49,32 \\
junho & 15,95 & 32,91 & 48,86 \\
julho & 15,88 & 32,24 & 48,12 \\
agosto & 14,23 & 31,39 & 45,62 \\
setembro & 16,94 & 25,68 & 42,62 \\
outubro & 13,29 & 26,97 & 40,26 \\
novembro & 11,65 & 27,79 & 39,44 \\
dezembro & 12,34 & 27,98 & 40,32 \\
\hline
\end{tabular}

0 mês de janeiro apresenta uma menor margem de comer cialização. Entretanto, nesta época, tratando-se de fim de entressa fra, os produtores estariam com pouco milho para ser comercializado. Maiores margens dos produtores se explicariam por estarem os mesmos efetuando funções de comercialização que geralmente são feitas pelos intermediários, como secagem e armazenamento. 
50.

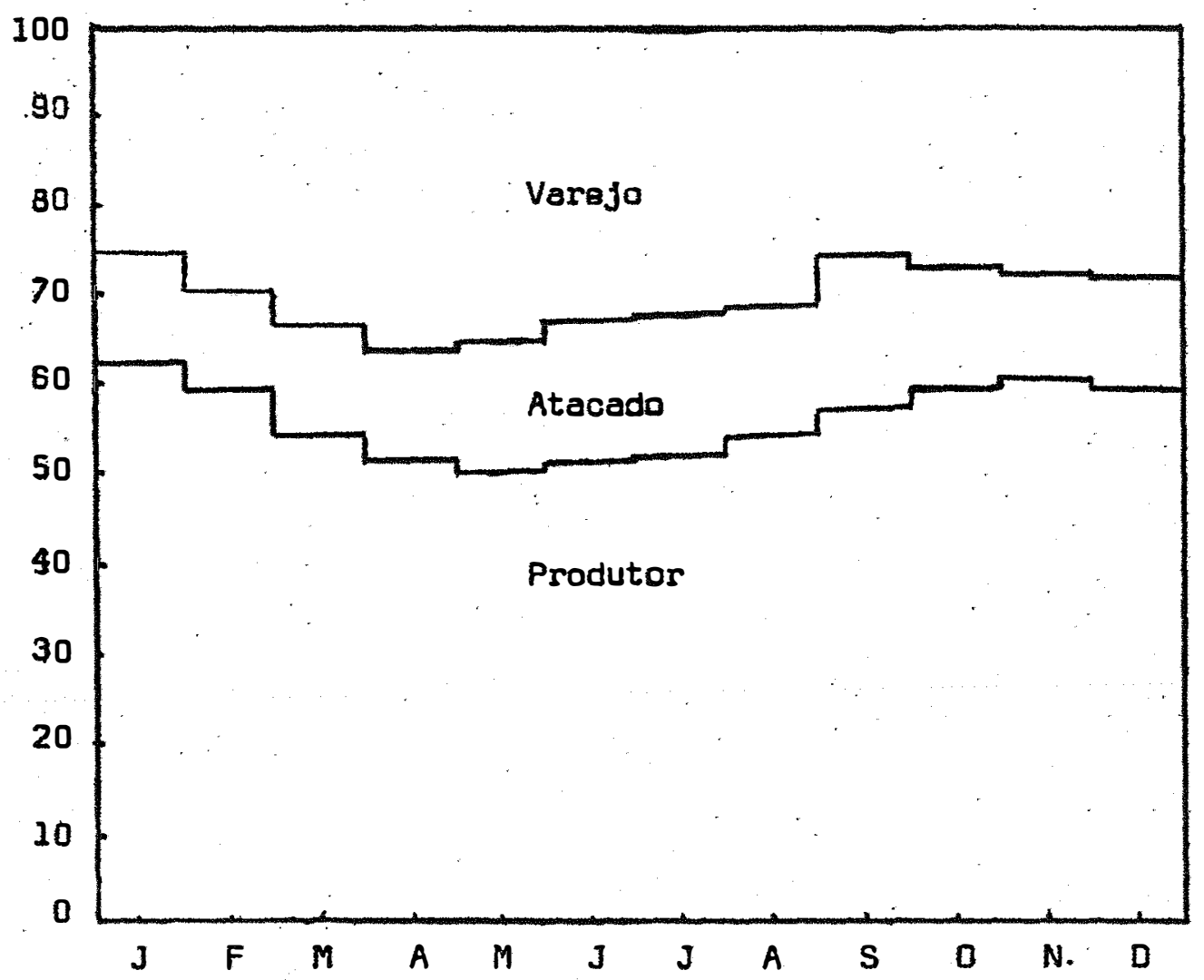

Fig. I - Mëdias mensais da margem do vareflsta, do atacadista e do produtor de milho, em porcentagens do preço no varejo, no Estado de São Paulo, perĹodo $1965 / 75$. 
A participação média $\stackrel{3 /}{ }$ do produtor no preço de vare jo, foi de 56,1\% no perfodo da pesquisa. A participação média do atacadista foi de $13,4 \%$ e a participação média do varejista de $33,5 \%$, este com menor participação nos meses de faneiro e setembro e maior no mês de abril.

Os valores das estimativas das margens absolutas,por centuais e os "markups" estão nas tabelas do apêndice 2.

Analisando o "markup" de atacado (tabela 30 do apêndice 2) tem-se que a participação do atacadista em relação ao preço recebido pelo produtor, variou de $64,1 \%$ (em janeiro) a $103,7 \%$ (em junhol, com média no perfodo de $83,7 \%$. A menor participação foi no mês de outubro de 1966, com 18,4\%.

0 "markup" de varejo (tabela 31 do apêndice 2), mostra a participação do varejista no preço do atacado. Sua média mensal variou de $37,2 \%$ (janeiro) a $60,0 \%$ (abril) com média no período de $47,8 \%$. O menor Indice obtido no perfodo foi de $2,8 \%$ em outubro de 1966.

Pela tabela 4 e figura 2 nota-se que durante o passar dos anos, ocorreu um aumento na participação dos intermediários em confunto no preço final do produto. Isto quer dizer que o produtor teve sua participação diminuida no preço pago pelo consumidor.

3/ Nos cálculos de média anual das margens utilizou-se da média arit mética. Seria mais adequado o uso da média ponderada, sendo a pondê ração feita, por exemplo, pelas quantidades do produto vendidas em cada mês, dados estes não existentes. 
Tabela 4 - Estimativa das médias anuais das margens do atacadista, do varejista, e de comercialização, para o Estado de São Paulo, período 1965/75. Valores expressos em porcentagem do preço de varejo.

\begin{tabular}{cccc}
\hline$\cap 0$ & $\begin{array}{c}\text { Margem do } \\
\text { Atacado } \\
\%\end{array}$ & $\begin{array}{c}\text { Margem do } \\
\text { Varejo } \\
\%\end{array}$ & $\begin{array}{c}\text { Margem de } \\
\text { Comercialização } \\
\%\end{array}$ \\
\hline 1965 & 16,31 & 13,77 & 30,08 \\
1966 & 14,09 & 17,08 & 31,17 \\
1967 & 15,13 & 26,55 & 41,68 \\
1968 & 18,18 & 25,13 & 43,31 \\
1969 & 15,57 & 28,18 & 43,75 \\
1970 & 13,08 & 34,49 & 47,57 \\
1971 & 12,51 & 34,25 & 46,76 \\
1972 & 11,74 & 36,69 & 48,43 \\
1973 & 10,69 & 33,20 & 43,89 \\
1974 & 11,18 & 40,03 & 51,21 \\
1975 & 8,91 & 46,27 & 55,18 \\
\hline
\end{tabular}

Um aspecto que chama a atenção é que o aumento napar ticipação dos intermediários como um todo, se deve ao aumento na par ticipação do varejista, porque a participação do atacadista também diminuiu no período. 
69.

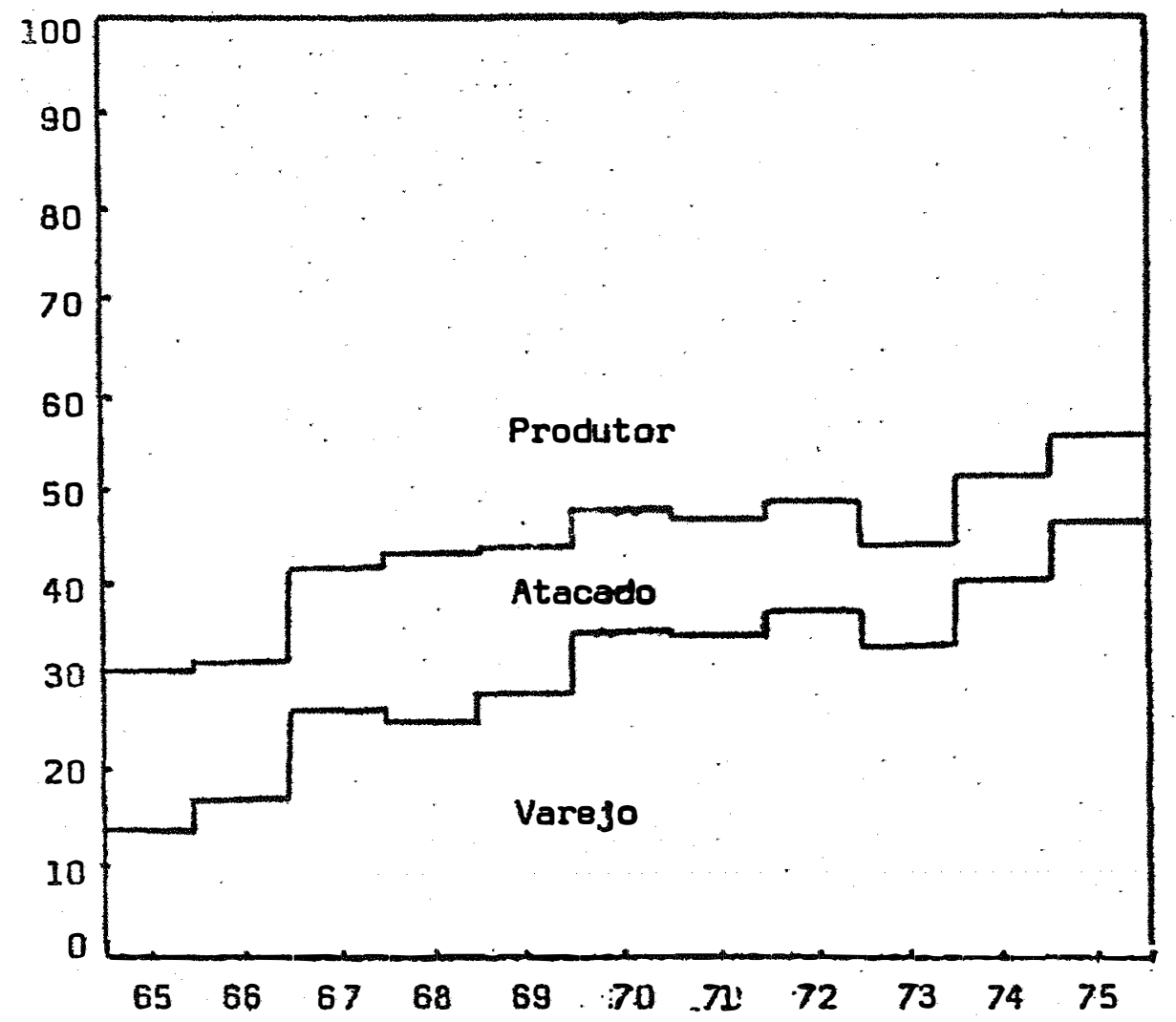

FIg. 2 - Evoluçēo das médlas anuals das margens do atacadista, do varejlsta e de camerclallzação; para o Estado de Sāo Paulo, perfodo 1965/75. Valores expressos en porcentagem do preço de varejo.

Serla Interessante un trabalho que analisasse a estrutura dos custos de comerclalização ao nÍvel de varejo, a fim de verlficar a razäo do aumento de sua margem com o passar dos anos. 
54.

\section{2 - Anälise Economëtrica das Margens}

A polftica de "markup" do atacadista em relação ao preço recebido pelo produtor pode ser caracterizada em todo o perío do, como sendo sempre "markup" relativo decrescente, mas não se pode rejeitar a hipótese de que a margem absoluta é constante em sete anos (1966, 1969, 1970, 1971, 1972, 1973 e 1974); em 3 anos (1965, 1968 e 1975) a margem absoluta é decrescente e no ano de 1967 é cres cente (tabela 5).

A caracterização da politica do varejista em relação ao preço real do atacado (tabela 6) mostra que o "markup" relativo é decrescente em todo o perílodo e que a margem absoluta em 3 anos (1967, 1971 e 1972) é decrescente, sendo que nos outros $\theta$ anos restantes da anālise não podemos rejeitar a hipótese de que a margem absoluta é constante.

O "markup" total de comercialização em relação ao pre ço real obtido pelo produtor pode ser caracterizado em todo o perío do da análise como sendo de valor relativo decrescente, quanto àmar gem absoluta, nos anos de 1967, 1971, 1972 e 1975 mostrou-se decres cente e nos outros 7 anos não podemos rejeitar a hipótese de que a margem absoluta é constante (tabela 7). 
Tabela 5 - Estimativa dos parâmetros da regressão linear da margem do atacadista em relação ao preço recebido pelo produtor (a), valores do teste $t$, coeficiente de determinação e caracterização da política de "markup" na comercialização de milho no Estado de São Paulo, período 1965/75.

\begin{tabular}{|c|c|c|c|c|c|c|}
\hline Ano & $\begin{array}{l}\text { Estimativa } \\
\text { do coefi- } \\
\text { ciente li- } \\
\text { near } \\
(\bar{\alpha})\end{array}$ & $\begin{array}{c}\text { Teste } t \\
\text { para } \hat{\alpha} \\
\text { (b) }\end{array}$ & 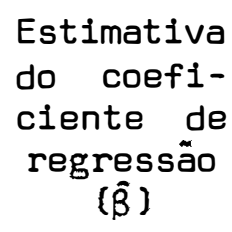 & $\begin{array}{l}\text { Teste } t \\
\text { para } \hat{\beta} \\
\text { (b) }\end{array}$ & $\begin{array}{l}\text { Coefici- } \\
\text { ente de } \\
\text { determi- } \\
\text { nação } \\
(\%)\end{array}$ & $\begin{array}{l}\text { Política } \\
\text { de } \\
\text { "markup" } \\
\text { (c) }\end{array}$ \\
\hline 1965 & 2,27 & $22,221^{* * *}$ & $-0,193$ & $2,162 * *$ & 31,8 & 0 \\
\hline 1966 & 0,90 & $6,505 * * *$ & 0,036 & 0,386 & 1,5 & $F$ \\
\hline 1967 & 0,52 & $4,275 * * *$ & 0,159 & $2,059 * *$ & 29,8 & $E$ \\
\hline 1968 & 1,96 & $41,141 * * *$ & $-0,154$ & $2,088^{* \star}$ & 30,4 & D \\
\hline 1969 & 1,88 & $17,004 * * *$ & $-0,076$ & 0,918 & 7,8 & $\mathrm{~F}$ \\
\hline 1970 & 1,52 & $12,577 * * *$ & $-0,040$ & 0,512 & 2,6 & $\mathrm{~F}$ \\
\hline 1971 & 1,68 & $17,258^{* * *}$ & $-0,098$ & 0,347 & 1,2 & $\mathrm{~F}$ \\
\hline 1972 & 1,57 & $13,434 * * *$ & $-0,044$ & 0,501 & 2,5 & $F$ \\
\hline 1973 & 0,67 & $3,521 * * *$ & 0,096 & 0,761 & 5,5 & $F$ \\
\hline 1974 & 3,20 & $12,195 * \star \star *$ & $-0,237$ & 0,941 & 8,1 & $\mathrm{~F}$ \\
\hline 1975 & 5,33 & $27,411 * * *$ & $-0,475$ & $2,641 * * *$ & 41,1 & 0 \\
\hline
\end{tabular}

(a) Valores reais, em cruzeiros $(1965-67=100)$.

(b) Um, dois e três asteriscos indicam significância ao nível de $10 \%$, $5 \%$ e $1 \%$, respectivamente.

(c) Ver tabela 2 . 
Tabela 6 - Estimativa dos parâmetros da regressão linear da margem do varejista em relação ao preço no atacado (a), valores do teste $t$, coeficiente de determinação e caracterização da política de "markup" na comercialização do milho no Estado de São Paulo, período 1965/75.

\begin{tabular}{|c|c|c|c|c|c|c|}
\hline Ano & $\begin{array}{l}\text { Estimativa } \\
\text { do coefi- } \\
\text { ciente li- } \\
\text { near } \\
(\bar{\alpha})\end{array}$ & $\begin{array}{c}\text { Teste } t \\
\text { para } \hat{\alpha} \\
\text { (b) }\end{array}$ & $\begin{array}{l}\text { Estimativa } \\
\text { do coefi- } \\
\text { ciente de } \\
\text { regressão } \\
(\hat{B})\end{array}$ & $\begin{array}{c}\text { Teste } t \\
\text { para } \hat{B} \\
\text { (b) }\end{array}$ & $\begin{array}{l}\text { Coefici- } \\
\text { ente de } \\
\text { determi- } \\
\text { nação } \\
(\%)\end{array}$ & $\begin{array}{l}\text { Política } \\
\text { de } \\
\text { "markup" } \\
\text { (c) }\end{array}$ \\
\hline 1965 & 2,40 & $9,051 * * *$ & $-0,196$ & 0,783 & 5,8 & $F$ \\
\hline 1966 & 2,84 & $11,937 * * *$ & $-0,234$ & 1,564 & 19,7 & $F$ \\
\hline 1967 & 5,66 & $20,139 * * *$ & $-0,478$ & $3,208 * * *$ & 50,7 & $D$ \\
\hline 1968 & 2,70 & $8,472^{* * *}$ & $-0,147$ & 0,262 & 0,7 & $F$ \\
\hline 1969 & 3,05 & $20,100^{* * *}$ & $-0,055$ & 0,464 & 2,1 & $F$ \\
\hline 1970 & 4,60 & $20,516^{* * *}$ & $-0,172$ & 1,177 & 12,2 & $F$ \\
\hline 1971 & 8,78 & $76,185^{* * *}$ & $-0,837$ & $3,421 * * *$ & 53,9 & $D$ \\
\hline 1972 & 9,16 & $37,968 * * *$ & $-0,709$ & $3,920 * * *$ & 60,6 & $D$ \\
\hline 1973 & 8,28 & $16,724^{* * *}$ & $-0,453$ & 1,602 & 20,4 & $F$ \\
\hline 1974 & 7,59 & $17,712^{* * *}$ & $-0,227$ & 0,610 & 3,6 & $F$ \\
\hline 1975 & 18,14 & $23,705^{\star * *}$ & $-1,043$ & 1,143 & 11,6 & $\mathrm{~F}$ \\
\hline
\end{tabular}

(a) Valores reais, em cruzeiros $(1965-67=100)$.

(b) Um, dois e três asteriscos indicam significância ao nível de 10\%, $5 \%$ e $1 \%$, respectivamente.

(c) Ver tabela 2. 
Tabela 7 - Estimativa dos parâmetros da regressão linear da margerii de comercialização em relação ao preço recebido pelo pro dutor (a), valores do teste $t$, coeficiente de determinação e caracterização da polftica de "markup" na comercia lização de milho no Estado de São Paulo, período 1965/75.

\begin{tabular}{|c|c|c|c|c|c|c|}
\hline Ano & $\begin{array}{l}\text { Estimativa } \\
\text { do coefi- } \\
\text { ciente li- } \\
\text { near } \\
(\hat{\alpha})\end{array}$ & $\begin{array}{c}\text { Teste } t \\
\text { para } \bar{\alpha} \\
\text { (b) }\end{array}$ & $\begin{array}{c}\text { Estimativa } \\
\text { do coefi- } \\
\text { ciente de } \\
\text { regressäo } \\
\text { (B) }\end{array}$ & $\begin{array}{l}\text { Teste } t \\
\text { para } \hat{\beta} \\
\text { (b) }\end{array}$ & $\begin{array}{l}\text { Coefici- } \\
\text { ente de } \\
\text { determi- } \\
\text { nação } \\
(\%)\end{array}$ & $\begin{array}{c}\text { Política } \\
\text { de } \\
\text { "markup" } \\
\text { (c) }\end{array}$ \\
\hline 1965 & 4,20 & $15,439 * * *$ & $-0,351$ & 1,478 & 17,9 & $\mathrm{~F}$ \\
\hline 1966 & 3,26 & $14,575^{* * *}$ & $-0,157$ & 1,035 & 9,7 & $\mathrm{~F}$ \\
\hline 1967 & 5,47 & $23,312^{* * *}$ & $-0,310$ & $2,101^{* *}$ & 30,6 & $D$ \\
\hline 1968 & 3,42 & $11,600 * * *$ & $-0,050$ & 0,110 & 0,1 & $F$ \\
\hline 1969 & 4,46 & $39,811^{* * *}$ & $-0,061$ & 0,720 & 4,9 & $F$ \\
\hline 1970 & 5,61 & $27,358^{* * *}$ & $-0,159$ & 1,198 & 12,5 & $\mathrm{~F}$ \\
\hline 1971 & 9,37 & $79,893^{* * *}$ & $-0,911$ & $3,026^{* * *}$ & 47,8 & $D$ \\
\hline 1972 & 9,41 & $40,003^{* * *}$ & $-0,686$ & $3,901 * * *$ & 60,3 & $D$ \\
\hline 1973 & 6,51 & $16,387 * * *$ & $-0,110$ & 0,414 & 1,7 & $F$ \\
\hline 1974 & 9,61 & $20,700 * * *$ & $-0,345$ & 0,775 & 5,7 & $\mathrm{~F}$ \\
\hline 1975 & 29,39 & $51,611 * * *$ & $-2,489$ & $4,728 * * *$ & 69,1 & $D$ \\
\hline
\end{tabular}

(a) Valores reais, em cruzeiros $(1965-67=100)$.

(b) Um, dois e três asteriscos indicam significância ao nível de 10\%, $5 \%$ e $1 \%$, respectivamente.

(c) Ver tabela 2 . 
58.

\section{3 - Elasticidade de Transmissão de Preço}

Os resultados das tabelas 8,9 e 10 indicam que os valores da elasticidade de transmissão de preço são menores do que 1 , o que está de acordo com a hipótese anteriormente formulada.

0 ano de 1975 mostrou-se como um ano atípico, por apresentar elasticidade de transmissão de preço negativa. Por 1sso, esse ano não será considerado na análise. Em médla, de acordo com a elasticldade da margem nos anos de 1965/74, se ocorresse uma variação de $10 \%$ no preço do produtor, ocorrería uma mudança de $4,0 \%$ no preço de varejo.

Conforme as pressuposições feltas anterlormente, verifica-se que a relação entre as elasticidades de demanda ao nível de varejo e ao nível do produtor, para o milho no Estado de São Pau 10 é:

$$
E_{a p_{a}}=0,4 E_{x p_{x}}
$$

A elasticidade de transmissão de preço do atacado mostra que, em médla, se ocorrer uma variação de $10 \%$ no preço recebido pelo produtor, ocorreria uma mudança de $7,6 \%$ no preço de ataca do.

A elasticidade de transmissão de preço do varejo,mos tra que, se ocorrer uma variação de 10\% no preço de atacado, ocorre rá uma mudança de $4,7 \%$ no preço de varejo. 
Tabela 8 - Elasticidade de transmissão de preço, expressando a porcentagem de variação no preço de varejo com a variação de 1 por cento no preço do produtor, para o milho no Estado de São Paulo, período $1965 / 75$.

\begin{tabular}{llccc}
\hline Ano & $1+\hat{\beta}_{1}$ & Média $P_{P}$ & Média $P_{V}$ & $\varepsilon$ \\
\hline 1965 & 0,649 & 5,376 & 7,692 & 0,454 \\
1966 & 0,843 & 5,405 & 7,812 & 0,583 \\
1967 & 0,690 & 5,398 & 9,194 & 0,405 \\
1968 & 0,950 & 4,159 & 7,372 & 0,536 \\
1969 & 0,939 & 5,393 & 9,527 & 0,531 \\
1970 & 0,841 & 5,330 & 10,022 & 0,447 \\
1971 & 0,088 & 5,231 & 9,832 & 0,047 \\
1972 & 0,314 & 5,801 & 11,232 & 0,162 \\
1973 & 0,890 & 7,317 & 13,026 & 0,500 \\
1974 & 0,655 & 6,824 & 14,105 & 0,317 \\
1975 & $-1,489$ & 7,829 & 17,735 & $-0,657$ \\
\hline
\end{tabular}


60.

Tabela 9 - Elasticidade de transmissão do preço, expressando a porcentagem de variação no preço de atacado com a variação de 1 por cento no preço do produtor, para o Estado de São Paulo, período 1965/75.

\begin{tabular}{ccccc}
\hline Ano & $1+\hat{\beta}_{2}$ & Média $P_{P}$ & Média $P_{a}$ & $\varepsilon_{A}$ \\
\hline 1965 & 0,807 & 5,376 & 6,685 & 0,649 \\
1966 & 1,036 & 5,405 & 6,495 & 0,862 \\
1967 & 1,159 & 5,398 & 6,780 & 0,923 \\
1968 & 0,846 & 4,159 & 5,477 & 0,642 \\
1969 & 0,924 & 5,393 & 6,859 & 0,726 \\
1970 & 0,960 & 5,330 & 6,634 & 0,771 \\
197. & 0,913 & 5,231 & 6,461 & 0,739 \\
$197 \%$ & 0,956 & 5,801 & 7,113 & 0,780 \\
1973 & 1,096 & 7,317 & 8,684 & 0,923 \\
1974 & 0,763 & 6,824 & 8,437 & 0,617 \\
1975 & 0,525 & 7,829 & 9,443 & 0,435 \\
\hline
\end{tabular}


Tabela 10 - Elasticidade de transmissão de preço, expressando a por centagem de variação no preço de varejo, com a variação de 1 por cento no preço de atacado, para o milho no Estado de São Paulo, período de $1965 / 75$.

\begin{tabular}{lrccc}
\hline Ano & $1+\bar{\beta}_{3}$ & Média $P_{a}$ & Média $P_{v}$ & $\varepsilon_{V}$ \\
\hline 1965 & 0,804 & 6,685 & 7,692 & 0,699 \\
1966 & 0,766 & 6,495 & 7,812 & 0,637 \\
1967 & 0,522 & 6,780 & 9,194 & 0,385 \\
1968 & 0,853 & 5,477 & 7,372 & 0,634 \\
1969 & 0,945 & 6,859 & 9,527 & 0,680 \\
1970 & 0,828 & 6,634 & 10,022 & 0,548 \\
1971 & 0,163 & 6,461 & 9,832 & 0,107 \\
1972 & 0,291 & 7,113 & 11,232 & 0,184 \\
1973 & 0,547 & 8,684 & 13,026 & 0,365 \\
1974 & 0,773 & 8,437 & 14,105 & 0,462 \\
1975 & $-0,043$ & 9,443 & 17,735 & $-0,023$ \\
\hline
\end{tabular}




\section{4 - Variação Estacional}

Nesta secção procurou-se verificar o comportamento sa zonal do preço do milho nos três níveis de comercialização.

Ao nível de produtor verifica-se que o valor mínimo médio do índice sazonal foi no mès de junho $(87,8)$ e o máximo $(116,1)$ em janeiro. Isto pode ser explicado pelo fim da safra em junho e tam bém pelo fim da entressafra em janeiro. Já o fndice estacional atin giu o mínimo em julho de $1966(77,9)$ e o máximo em fevereiro de 1967 $(139,2)$, como mostra a tabela 11 .

Quanto ao nível de atacado, o índice sazonal variou de 91,2 em maio a 111,9 em janeiro. 0 índice estacional atingiu o mínimo em julho de $1966(78,8)$ e o máximo em fevereiro de 1967 $(140,4)$, resultados expressos na tabela 12 .

No varejo, o indice sazonal variou de 93,1 em setembro a 107,6 em fevereiro. O índice estacional em setembro de 1966 atingiu o seu ponto de mínimo $(81,6)$ e em fevereiro de 1967 atingiu o seu ponto de máximo $(122,8)$, como mostra a tabela 13. Pelo que se notou, os menores indices estacionais ocorreram no ano de 1966.

No apéndice 3 encontram-se as tabelas da análise de variância dos índices, sendo que nos três níveis o teste $F$ apresentou-se significativo. Portanto rejeita-se a hipótese de que os índi ces estacionais são iguais.

Na tabela 14 apresenta-se os índices sazonais nos três níveis de comercialização, com seus limites inferior e supe- 


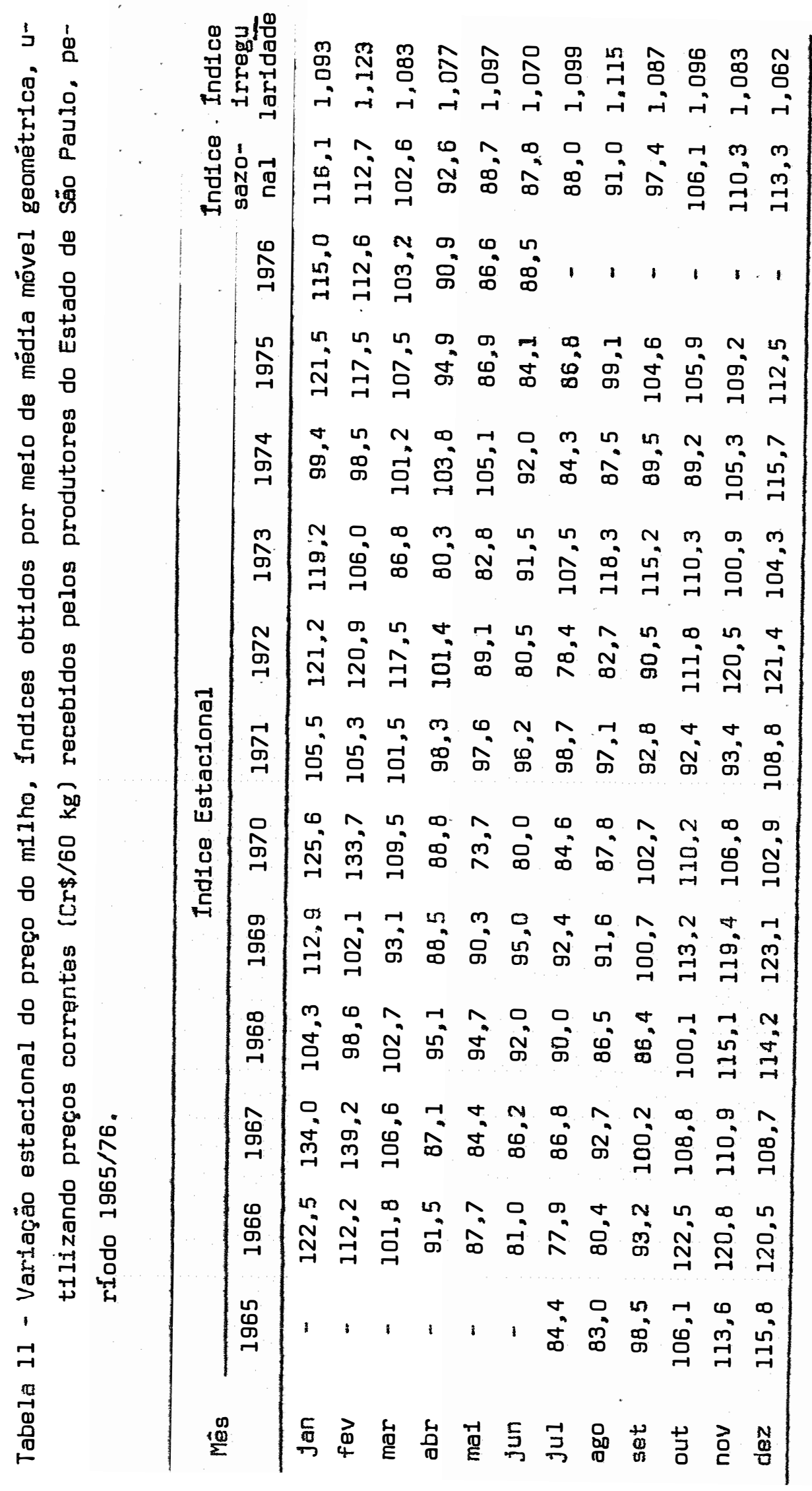




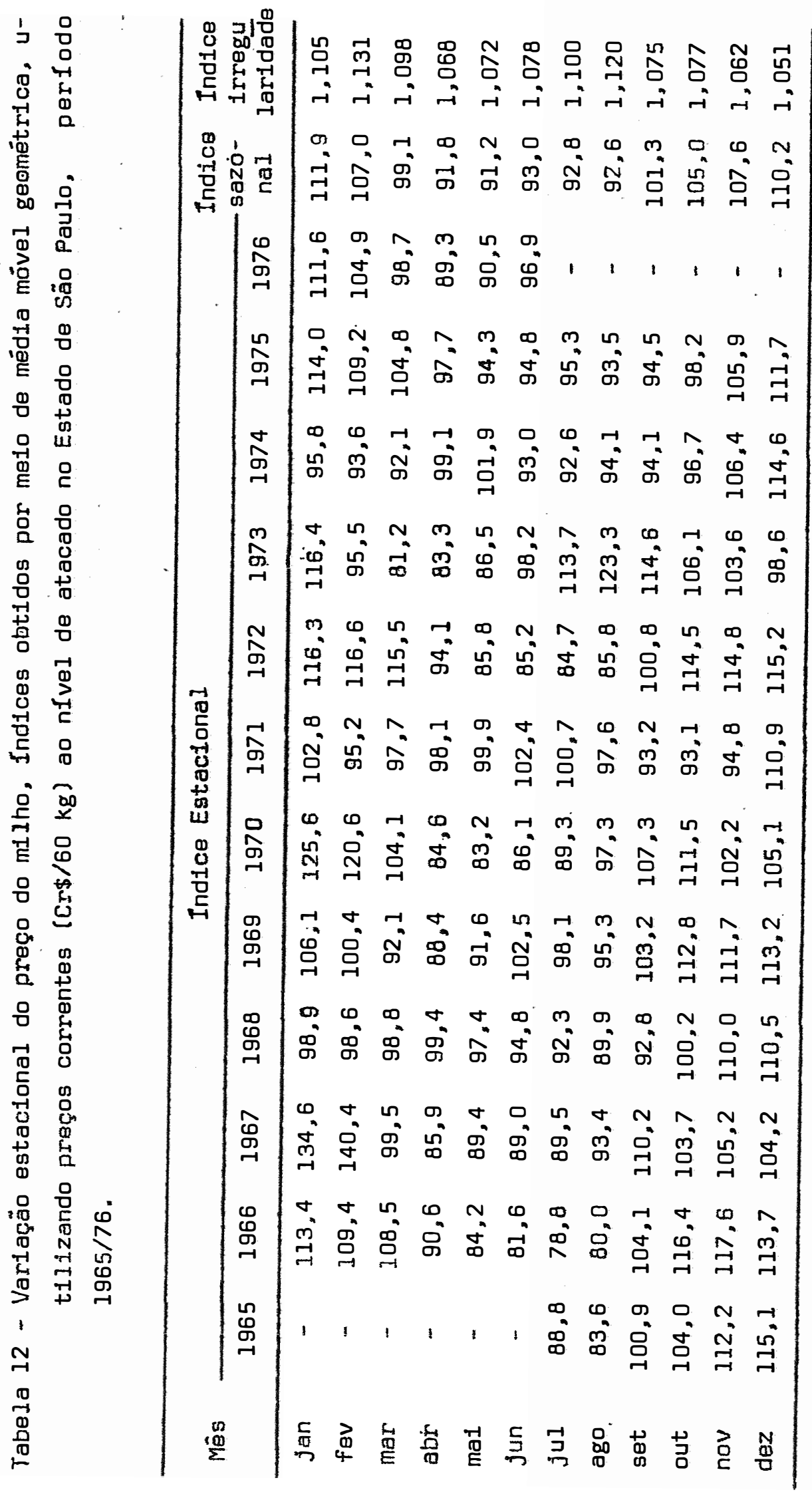

64. 


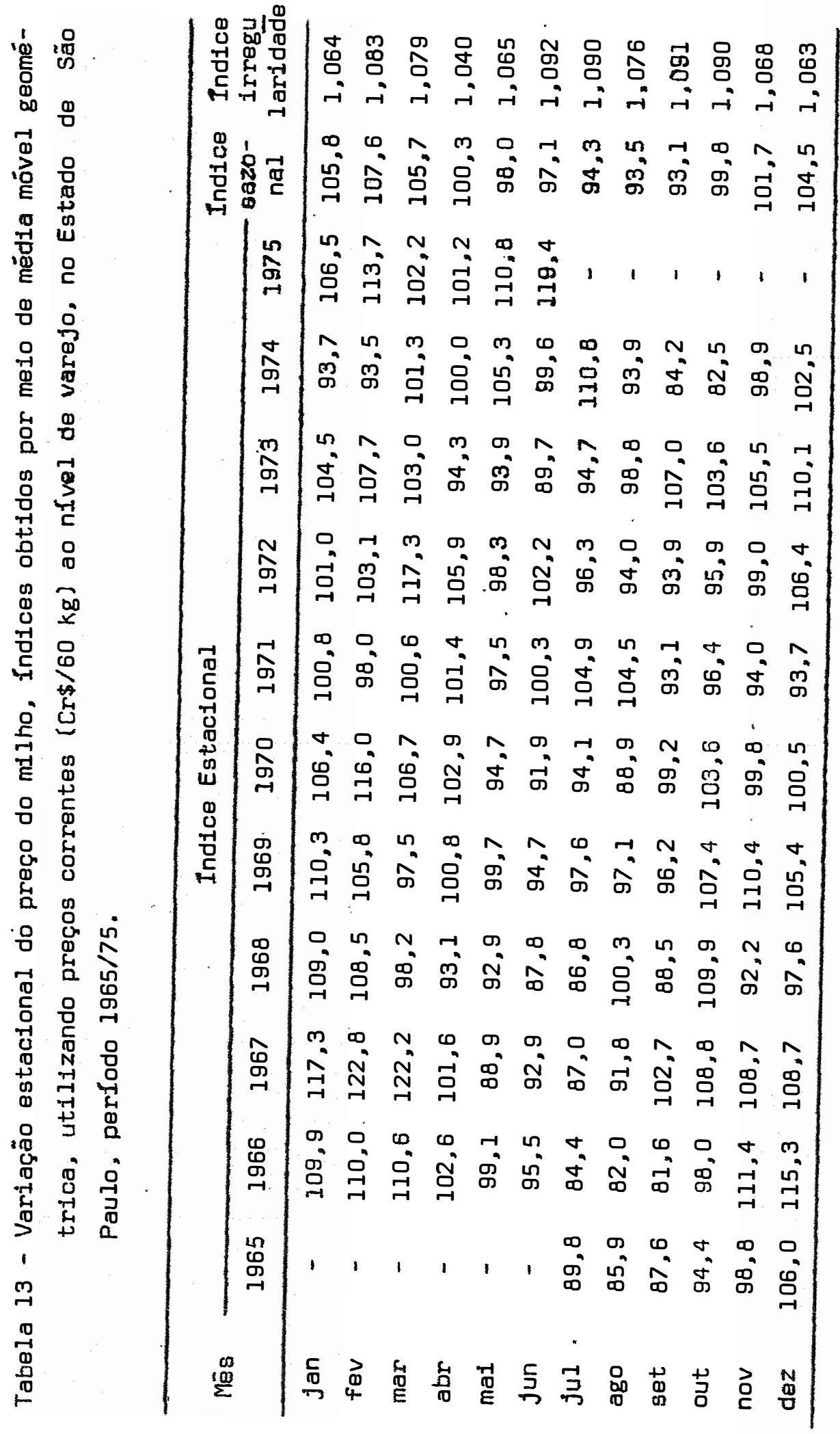


66.

rior. Com estes dados foram construídas as figuras 3,4 e 5 .

As amplitudes dos indices sazonais obtidas foram as seguintes: 28,$3 ; 20,7$ e 14,5 respectivamente para o produtor, ataca do e varejo, o que está de acordo com os resultados da secção anterior.

Naquela secção observou-se que a relação entre as elasticidades de demanda aos níveis do atacado e do produtor foi de 0,76 e a relação entre a elasticidade ao nível do varejo e ao nível do atacado foi da ordem de 0,47 . Portanto a demanda é mais elástica ao nível de atacado do que ao nível de produtor e ao nível de varejo do que ao nível de atacado. Assim avariações na oferta ao nível do produtor causarão variações de preço menores ao nível de atacado e menores ainda ao nível do varejo, confirmando assim a previsão feí ta no capitulo 3 .

Dificuldades de crédito e armazenamento tendem a cau sar maiores oscilações da oferta disponível no correr do ano. Oscilações dessa oferta causam variações maiores nos preços recebidos pelos produtores. Esses efeitos são sempre atenuados nos outros niveis do processo de comercialização.

Comparando os resultados obtidos por HOFFMANN (1969a) em relação ao preço do milho recebido pelo produtor, temos que em ja neiro, fevereiro, março e dezembro, os indices obtidos neste trabaIho foram menores em relação aos três períodos por ele considerados e os índices de Junho, Julho, agosto e setembro foram maiores. Os Indices de irregularidade obtidos para os meses de março, abril, 
67.

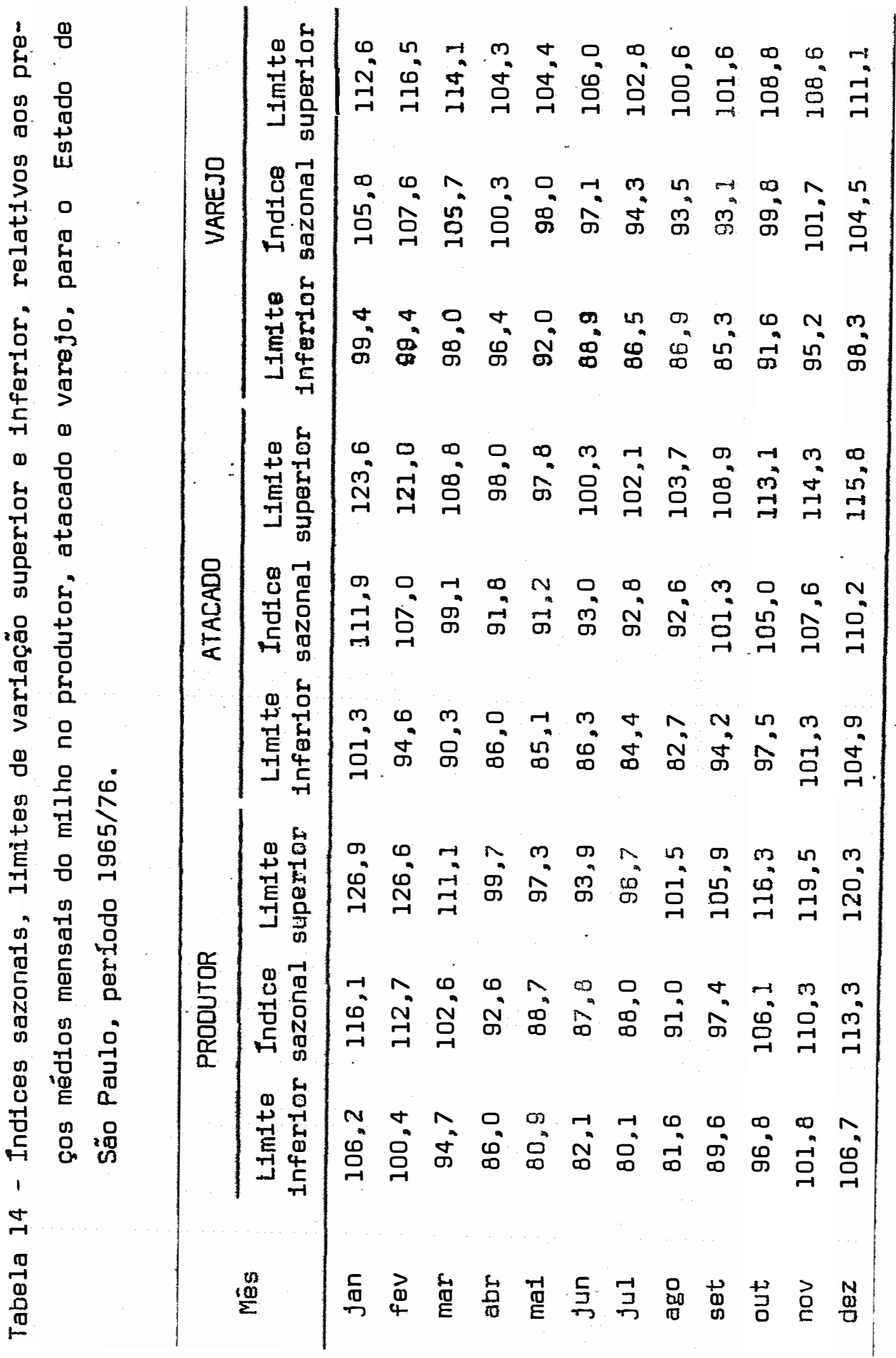


68.

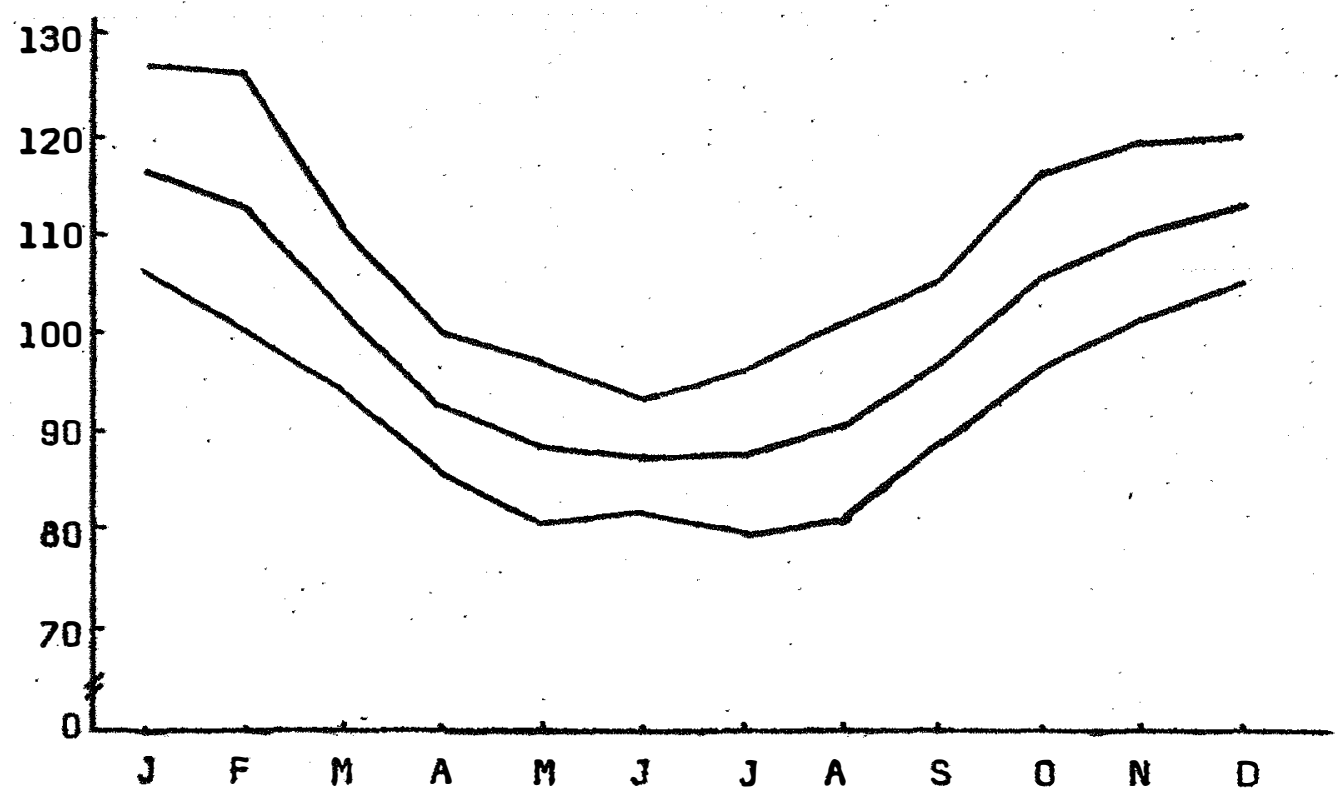

FIg. 3 - Variação estacional dos preços médios do milho recebidos pe los produtores do Estado de São Paulo, 1965/76.

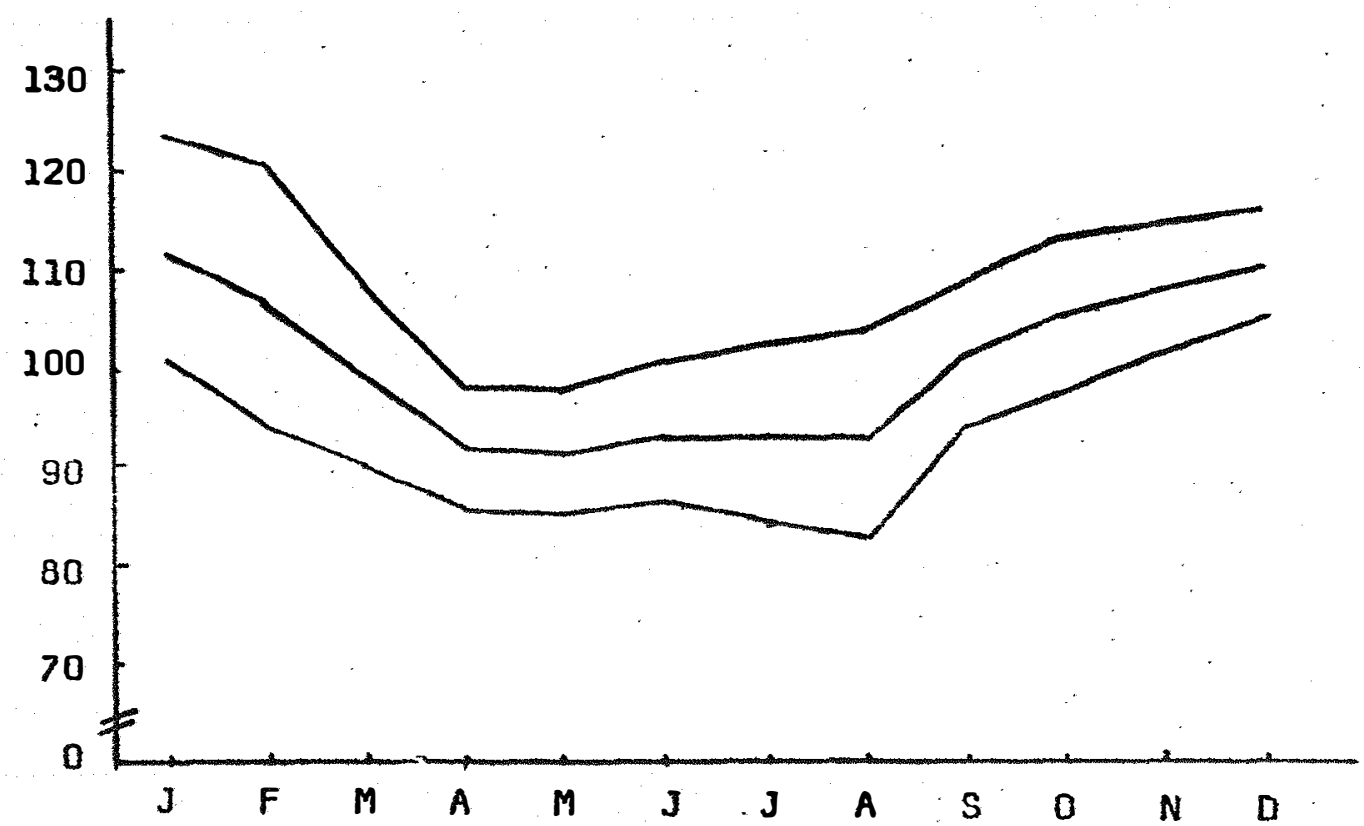

Fig. 4 - Variação estactonal dos preços mádilos do milho no atacado do Estado de São Paulo, $1965 / 76$. 
69.

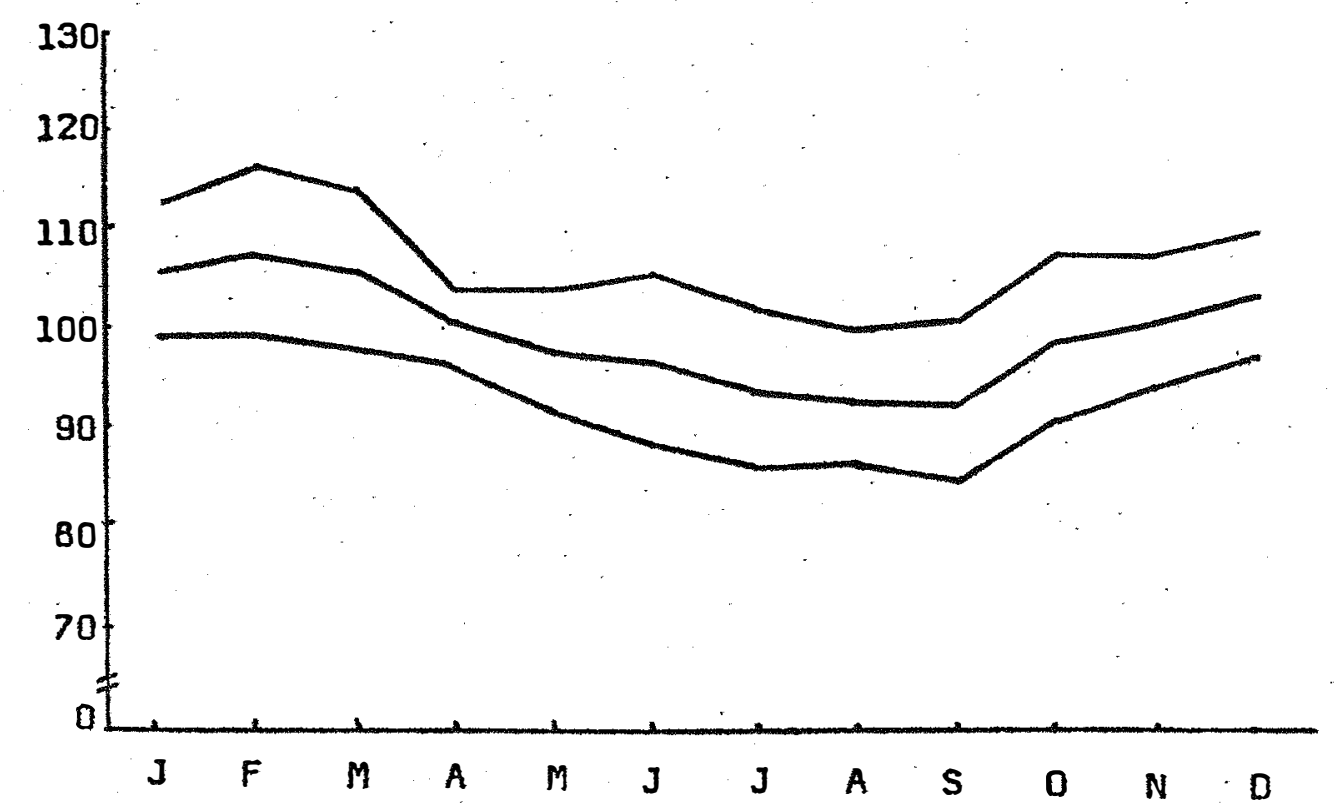

Fig. 5 - Varlação estacional dos preços médios do milho no varejo do Estado de São Paulo, $1965 / 75$.

malo e Junho foram malores que os obtidos por Hoffimann nos três perlodos. Comparando a flgura 3 deste trabalho com a figura 58 do tre balho citado, notarse que a amplitude de varłaçäo diminulu, portanto os preços tenderam a se estabilizar com o passar do tempo.

Comparando os resultados de WALDER (1976) referentes aos preços recebidos pelos produtores no período $1966 / 75$ para o Estado de Espírito Santo, tem-se que o Indice sazonal nos meses de de zembro a malo, en São Paulo, foram malores que os do Espirito Santo, porém para os meses de abril a novembro o Inverso ocorreu. 


\section{5 - Armazenagem}

Apresentasse inicialmente uma análise de armazenagem do milho no CEAGESP.

Analisando a tabela 15, observa-se que as quantidades máximas de milho armazenado são atingidas, em sua maioria, em agosto e setembro (fim da safra no Estado de São Paulo) e os valores mínimos em sua maioria ocorrem em março e abril (fim da entressafra e início da safra).

Tabela 15 - Participação do volume máximo, médio e mínimo anual de mi lho armazenado, na capacidide de armazenagem do CEAGESP, período 1965/76.

\begin{tabular}{|c|c|c|c|c|c|c|c|c|c|}
\hline \multirow{2}{*}{ Ano } & \multirow{2}{*}{$\begin{array}{c}\text { Capacidade } \\
\text { total } \\
\text { (t) }\end{array}$} & \multicolumn{8}{|c|}{ Armazenado (t) } \\
\hline & & máximo & mês & $\%$ & médio & $\%$ & mínimo & mês & $\%$ \\
\hline 1965 & 534400 & 104558 & set & 19,56 & 52056,1 & 9,74 & 2061 & abr & 0,38 \\
\hline 1966 & 570600 & 113307 & ago & 19,86 & 72840,6 & 12,76 & 41920 & dez & 7,35 \\
\hline 1967 & 586000 & 154077 & ago & 26,29 & 84740,9 & 14,46 & 8368 & $\operatorname{mar}$ & 1,43 \\
\hline 1968 & 589500 & 175015 & ago & 29,69 & 115250,7 & 19,55 & 54947 & mar & 9,32 \\
\hline 1969 & 616500 & 131373 & ago & 21,31 & 81557,9 & 13,23 & 31410 & $a b r$ & 5,09 \\
\hline 1970 & 634700 & 178114 & set & 28,06 & 97255,5 & 15,32 & 8853 & mar & 1,39 \\
\hline 1971 & 778100 & 182081 & ago & 23,40 & 114875,0 & 14,76 & 45362 & mar & 6,99 \\
\hline 1972 & 862500 & 173852 & ago & 20,16 & 106906,1 & 12,39 & 16814 & $\operatorname{mar}$ & 1,95 \\
\hline 1973 & 888200 & 212720 & ago & 23,95 & 139017,9 & 15,65 & 53668 & abr & 6,04 \\
\hline 1974 & 1124000 & 275696 & out & 24,53 & 174626,9 & 15,54 & 76065 & $a b r$ & 6,77 \\
\hline 1975 & 1102000 & 264515 & ago & 24,00 & 168882,2 & 15,32 & 74228 & mar & 6,73 \\
\hline 1976 & 1312000 & 210737 & set & 16,06 & 137648,7 & 10,49 & 38829 & $\operatorname{mar}$ & 2,96 \\
\hline
\end{tabular}


Os valores máximos do período $1965 / 76$ variaram de $16 \%$ a $29,7 \%$ da capacidade total do CEAGESP. 0 valor médio variou de $9,7 \%$ a $19,5 \%$ e o mínimo de $0,4 \%$ a $9,3 \%$ da capacidade total existente.

0 ano em que ocorreu maiores Indices de ocupação da capacidade de armazenagem do CEAGESP foi o de 1968, em que o milho ocupou de $9,3 \%$ a $29,7 \%$ da capacidade, respectivamente em março e agosto. Em média, no período de 1965 a 1976 o milho ocupou 14\% da ca pacidade de armazenagem.

Considerando o porcentual da produção que é armazena da no CEAGESP (tabela 16), verifica-se que as porcentagens variaram de $4,3 \%$ a $12,6 \%$ da produção do Estado. Em média, 7,1\% da produção foram armazenadas no CEAGESP.

Nota-se na tabela 17 (ou figura 6) que a produção de milho em São Paulo evoluiu muito pouco, passando por altas e baixas. Já a capacidade de armazenagem do CEAGESP subiu do indice $100 \mathrm{em}$ 1965 para 245,4 em 1976. A quantidade de milho armazenada, considerando-se o máximo anual, cresceu até 1974, depois decresceu. 0 seu Indice no período $1965 / 75$ sempre foi maior que o indice de capacida de de armazenamento. 
Tabela 16 - Produção, quantidade máxima armazenada e porcentagem do armazenado em relação à produção, no CEAGESP, período 1965/76.

\begin{tabular}{cccc}
\hline Anq & $\begin{array}{c}\text { Produção } \\
(t)\end{array}$ & $\begin{array}{c}\text { Armazenado } \\
(t)\end{array}$ & $\%$ \\
\hline 1965 & 2448000 & 104558 & 4,27 \\
1966 & 2490000 & 113307 & 4,55 \\
1967 & 2640000 & 154077 & 5,84 \\
1968 & 2550000 & 175015 & 6,86 \\
1969 & 1740000 & 131373 & 7,55 \\
1970 & 2820000 & 178114 & 6,32 \\
1971 & 2760000 & 182081 & 6,60 \\
1972 & 3000000 & 173852 & 5,79 \\
1973 & 2598000 & 212720 & 8,19 \\
1974 & 2628000 & 275696 & 10,49 \\
1975 & 2100000 & 264515 & 12,59 \\
1976 & 2724000 & 210737 & 7,74 \\
\hline Média & 2541500 & 181337 & 7,13 \\
\hline
\end{tabular}

Fonte: IEA e CEAGESP. 
Tabela 17 - Evoluçãa da produção de milho no Estado de São Paulo, da capacidade de armazenagem do CEAGESP e dos estoques máximos de milho, perf́ado de 1965 a 1976, em toneladas.

\begin{tabular}{lcrrcccc}
\hline Ano & $\begin{array}{c}\text { Produção } \\
(t)\end{array}$ & Indice & $\begin{array}{c}\text { Capacidade } \\
(t)\end{array}$ & Indice & $\begin{array}{c}\text { Armazenado } \\
(t)\end{array}$ & Indice \\
\hline 1965 & 2448000 & 100,0 & 534400 & 100,0 & 104558 & 100,0 \\
1966 & 2490000 & 101,7 & 570600 & 106,8 & 113307 & 108,4 \\
1967 & 2640000 & 107,8 & 586000 & 109,6 & 154077 & 147,4 \\
1968 & 2550000 & 104,2 & 589500 & 110,3 & 175015 & 167,4 \\
1969 & 1740000 & 71,1 & 616500 & 115,4 & 131373 & 125,6 \\
1970 & 2820000 & 115,2 & 634700 & 118,8 & 178114 & 170,3 \\
1971 & 2760000 & 112,7 & 778100 & 145,6 & 182081 & 174,1 \\
1972 & 3000000 & 122,5 & 862500 & 161,4 & 173852 & 166,3 \\
1973 & 2598000 & 106,1 & 880200 & 166,2 & 212720 & 203,4 \\
1974 & 2628000 & 107,3 & 1124000 & 210,3 & 275696 & 263,7 \\
1975 & 2100000 & 85,8 & 1102000 & 206,2 & 264515 & 253,0 \\
1976 & 2724000 & 111,3 & 1312000 & 245,5 & 210737 & 201,5 \\
\hline
\end{tabular}




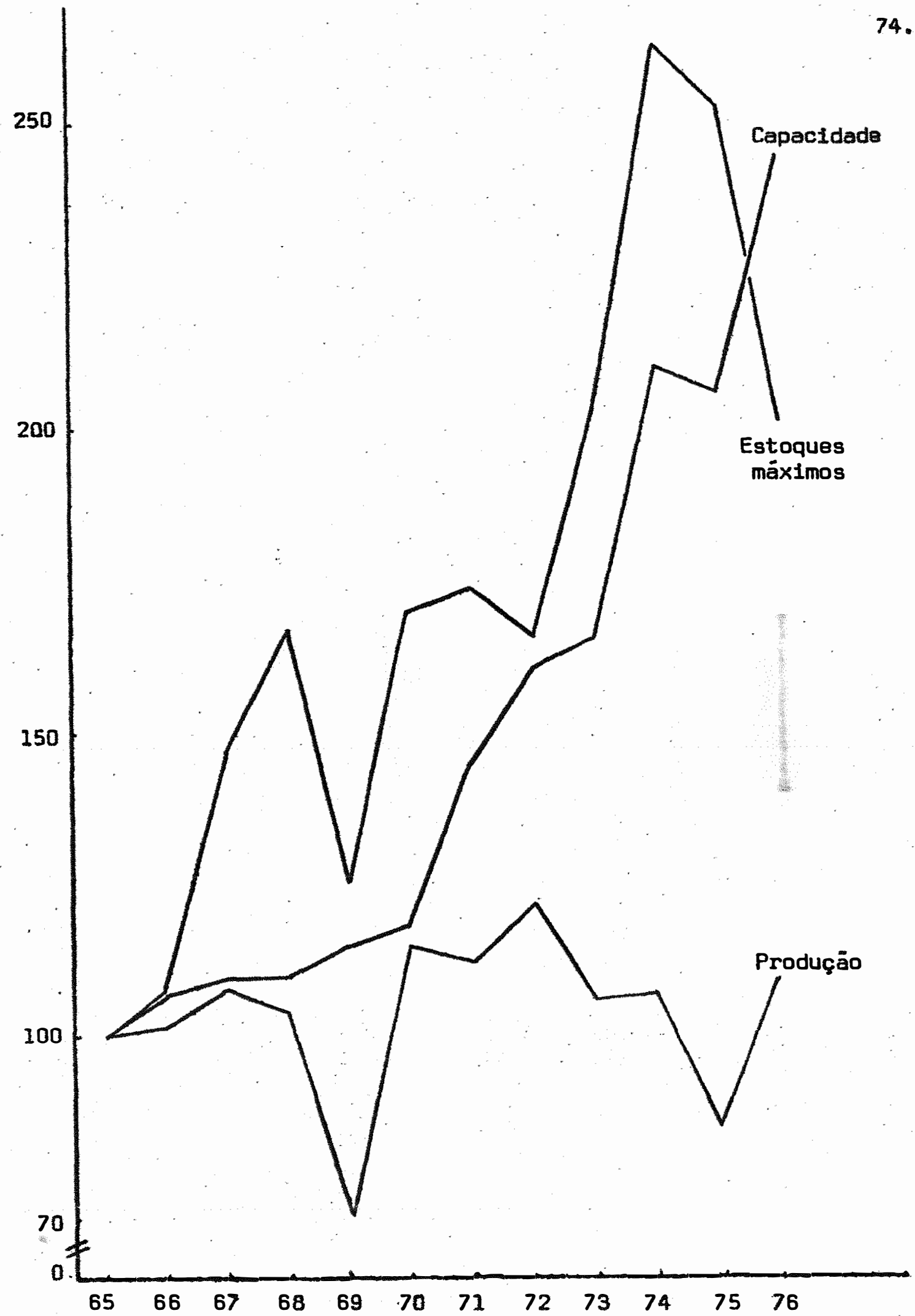

Fig. 6 - Evoluçāo da produçāo de milho, capacidade de armazenagem do CEAGESP a dos estoques máximos de milho, no Estado de' Séo Paulo, perfodo 1965/76. Indices: 1965 igual a 100. 


\subsection{1 - Demanda de armazenagem}

Os resultadas da relação entre quantidade armazenada e preço obtido pelo ajustamento da forma reduzida, pelo método dos mínimos quadrados ordinárías, estão na tabela 18 .

Tabela 18 - Resultado do ajustamento da forma reduzida, perfodo de junho de 1965 a dezembro de 1975 .

$$
\begin{array}{lr}
\ln Q_{t}-\ln Q_{t-1}=0,0079 & -0,6288\left(\ln P_{t}-\ln P_{t-1}\right)- \\
& -1,755) \\
& (8,080) \\
F=32,65 & \bar{r}^{2}=31,95 \% \\
d=2,116 & h=-1,2573
\end{array}
$$

Matriz dos coeficientes de correlação simples dos logaritmos das variáveis

$$
\begin{aligned}
& \ln P_{t}-\ln P_{t-1} \quad \ln Q_{t-1}-\ln Q_{t-2} \quad \ln Q_{t}-\ln Q_{t-1} \\
& \ln P_{t}-\ln P_{t-1} \quad 1,0000 \quad 0,1991 \quad-0,0105 \\
& \ln Q_{t-1}-\ln Q_{t-2} \quad 1,0000 \quad 0,5559 \\
& \begin{array}{ll}
\ln Q_{t}-\ln Q_{t-1} & 1,0000
\end{array}
\end{aligned}
$$

Entre parênteses, na tabela 18, temos os valores para o teste " $t$ ". 0 coeficiente da variável independente é estatisti- 
camente significativa ao nível de $10 \%$ e o cosficiente da variável de pendente defasada é significativo ao nível de $1 \%$

D teste $F$ é significativo ao nível de $1 \%$ de probabilidade, com o que se rejeita a hipótese de nulidade dos parâmetros. o coeficiente de determinação corrigido que se obteve pode ser considerado razoável, dado que se trabalhou com uma úni ca variāvel independente para explicar as variações nos estoques.

A estatística "d" nos diz que não existe autocorrela ção nos resíduos. Mas este teste não é próprio para análise de autocorrelação dos resíduos em ajustamentos que possuem a variável de pendente defasada. Aplicou-se então o teste Durbin (h), cuja estima tiva é menor que 1,645, significando que não se rejeita a hipótese de não autocorrelação nos resíduos ao nível de $5 \%$. Este é um teste válido somente para grandes amostras $(n>30$ ) e nada se sabe sobre suas propriedades para pequenas amostras (ver JOHNSTON, 1972) 4/. A não existência de correlação nos resíduos permite que as presentes estimativas sejam tomadas como consistentes. Além disso, essas esti mativas apresentaram os sinais esperados.

Um aumento no preço do mès acarretará uma diminuição nos estoques. A elasticidade de expectativa obtida no ajustamento foi de 0,426 .

4/ Note que o teste implica que o coeficiente de $\ell n \varepsilon_{t-1}$ na expressão (20) não é estatisticamente diferente de zero, ou sejja, não rejeitamos a hipótese $\rho=\lambda$. Desde que $\lambda$ já foi aceito ser diferente de zero, o resultado do teste Durbin sugere que os erros $\varepsilon_{t}$ são autocorrelacionados. 
Passando da forma reduzida para a forma estrutural,

obtem-se

$$
\frac{Q_{t}}{Q_{t-1}}=1,019\left(\frac{P_{t+1}^{*}}{P_{t}}\right)^{1,095} .
$$

Portanto, aumentas na relação entre a expectativa de preço no més seguinte e o preço do mês levarão a uma maior quantida de armazenada no mês em relação ao mês passado.

A elasticidade de preço de curto prazo lcom respeito ao preço do mês) sugere que uma variação de $10 \%$ no preço do mês em relação ao mês anterior, conduz a uma variação de $6,3 \%$ na quantidade armazenada no mês em relação ao mês anterior no sentido contrário. Portanto com aumento do preço do mês, os estoques tendem a reduzir.

A elasticidade preço de longo prazo lcom respeito à expectativa no mês seguinte), sugere que uma variação de $10 \%$ no pre ço esperado para o mês seguinte em relação ao preço do mès, levará a uma variação de $10,9 \%$ na quantidade armazenada, no mesmo sentido. Isto significa que, se o preço esperado para o més seguinte for maior que o preço observado no mês, vai ocorrer uma diminuição de menor intensidade ou um aumento dos estoques. Isto se explica como se segue.

Sabemos que se $P_{t}$ aumenta, haverá uma redução no estoque no mès $t$. Na equação estrutural temos a mesma situação. Se ocorrer um aumento de $10 \%$ em $P_{t}$, o aumento em $P_{t+1}^{*}$ será menor do que o ocorrido em $P_{t}$, uma vez que a elasticidade de expectativa é menor 
que a unidade. Com isso temos que a razäo $P_{t+1}^{*} / P_{t}$ diminuirá, isto é, $\ell n P_{t+1}^{*}-\ell n P_{t} e ́$ maior que $\ell n P_{t}^{*}-\ell n P_{t-1}$ levando a uma redução no estopus, dado que o coeficiente $\{1,09\}$ é positivo.

\section{5 .2 - Limitações}

0 modelo utilizado não pretende explicar todo o comportamento da armazenador, e sim, sua reação a mudanças no preço. E forçoso reconhecer que a omissão de variáveis pode ter prejudicado as estimativas dos coeficientes. Porém o que se procurou, fundamentalmente, foi analisar variações nos estoques em função da expectativa de preço.

A utilização desta metodologia na análise de armazenagem em trabalhos futuros, poderá ser substancialmente enriquecida com introdução de outras variáveis. 
79.

\section{CONCLUSÃO}

0 presente trabalho analisa diversos aspectos do com portamento dos preços e da decisão de armazenagem do milho no Estado de São Paulo.

Analisou-se portanto o comportamento do preço recebi do pelo produtor, atacadista e varejista, durante o período 1965/75 e, também, a relação que ocorre entre o preço do atacado e a quanti dade armazenada no CEAGESP, obtendo as conclusões que são descritas a seguir.

A margem de comercialização média do milho no Estado de São Paulo, no período de 1965 a 1975 foi em torno de 43,9\% do pre ço do varejo, e o valor médio mensal variou de $37,6 \%$ em janeiro a 49,3\% em maio. 0 valor médio da margem do varejista, conforme o mês, é 2,3 a 3 vezes maior que o valor médio da margem do atacadista. 
A participação média do produtor no preço de varejo foi de 56.1\% no período da pesquisa, a do varejista foi de $30,5 \%$ e a do atacadista de $13,4 \%$. Já a participação do atacadista em relação ao produtor foi em médía de $83,7 \%$ e a do varejista no preço do atacadista foi em média de 47,8\%. Um porto importante a se assinalar é o aumento da participação do varejista no preço, com queda na par ticipação do produtor e do atacadista.

Quanto à anālise econométrica, o "markup" relativo mostrou-se decrescente em todo o período, para os trēs níveis e não podemos rejeitar a hipótese de que a margem absoluta é constante. Fa zendo análise da elasticidade de transmissão de preço, observa-se que sempre foi menor do que 1, como se esperava. Em geral, se ocorrer uma variação de $10 \%$ no preço do produtor, é de se esperar uma variação de $4,0 \%$ no preço do varejo, no mesmo sentido.

Tanto a elasticidade de transmissão de preço do atacado, como do varejo, foram menores do que 1. Portanto, se ocorrer uma variação de 10\% no preço ao nível do produtor, haverá uma varía ção de 7,6 no preço de atacado e uma variação de $10 \%$ no preço de atacado levaría a uma varíação de $4,7 \%$ no preço de varejo; estas variações são sempre no mesmo sentido.

A amplitude de variação do índice sazonal para o pro dutor, atacadista e varejista foi respectivamente 28,$3 ; 20,7$ e 14,5; portanto o preço recebido pelos produtores variaram mais do que os do atacado e estes mais do que os do varejo. Maiores variações de preço em todos os níveis ocorreriam nos anos de maiorés safras. 
A análise dos dados mensais sobre a quantidade de $\mathrm{mi}$ Iho armazenado no CEAGESP no período 1965/76, mostra que, o valor má ximo anual estocado de milho variou de $16 \%$ a $29,7 \%$ da capacidade to tal e os valores mínimos de $0,4 \%$ a $9,3 \%$, sendo 0 ano de 1968 o que apresentou maior taxa de armazenagem. Em média, no perfodo 1965/76, - milho ocupou 14\% da capacidade de armazenagem do CEAGESP. Estes $14 \%$ representam $7,1 \%$ da produção média do Estado no perf́odo. Houve também um aumento constante da capacidade de armazenagem e da quantidade de milho armazenado, enquanto a produção do Estado permaneceu quase constante.

Quanto à expectativa de preço futuro dos usuários do CEAGESP, conseguiu-se um bom ajustamento do modelo, os parâmetros com significância ao nível de $10 \%$ e sem autocorrelação nos resíduos.

A elasticidade-preço de curto prazo (com respeito ao preço do mês] sugere que se ocorrer uma variação de $10 \%$ no preço do mês em relação ao mês anterior, haverá uma variação de $6,3 \%$ nos estoques do mês em relação ao do mês anterior, mas em sentido contrárío. Já a elasticidade-preço de longo prazo (com respeito ao preço esperado no mês seguinte) sugere que uma variação de $10 \%$ no preço esperado para o mês seguinte em relação ao preço do mês leva a uma variação de $10,9 \%$ nos estoques, e no mesmo sentido da variação do preço. 


\section{1 - Principais Implicações da Pesquisa}

Nesta secção pretende-se ressaltar as implicações da presente pesquisa não só para os produtores e intermediários diretạ mente envolvidos,como também, e principalmente, para os estudiosos do assunto.

Primeiramente deve-se fazer uma consideração de ordem teórica. O presente trabalho utilizou-se de um modelo competiti vo (proposto por Gardner) para a análise do comportamento dos preços de milho, e, apesar das imperfeições existentes no mundo real, os resultados obtidos apresentaram-se de acordo com as previsões do citado modelo. Esse fato torna-o recomendável para aplicações em ou tras situações. Outro aspecto importante é que esse modelo se presta para análise de dados agregados, de disponibilidade imediata. Nes se sentido, vale salientar que utilizando preços médios de mercado, o estudo permitiu somente análises ao nível de mercado. Assim, mesmo a análise de políticas de "markup" apresentada não se refere a nenhum agente ou intermediário em particular, mas ao conjunto de agentes operando num dado nível de mercado.

Do lado mais pragmätico, os resultados do presente trabalho parecem ter contribuido para um melhor entendimento do fun cionamento do mercado de milho no Estado de São Paulo. Sabe-se que qualquer mercado tende a se comportar de acordo com a natureza da demanda pelo produto envolvido. Com relação ao presente trabalho, em bora não visasse a descrição dessa demanda, contribuiu para a com- 
preensäo de sua estrutura.

0 ponto fundamental para o entendimento do comportamento dos preços do milho está na verificação de que as demandas ten dem a se tornar menos elástica quando se passa do consumidor para o produtor. Essa constatação, que foi possível graças à determinação da elasticidade de transmissão de preços, permitiu que se entendesse o porquē de os preços apresentarem diferentes padrões de variação, nos diferentes níveis de mercado. Assim, sabendo-se que a demanda ao nível do produtor é uma função derivada da demanda ao nível do consumidor, e que a primeira é menos elástica do que a segun da, conclui-se que para uma dada variação na quantidade comercializada, os preços variarão mais ao nível do produtor do que ao nível do consumidor.

Esse tipo de relação entre as elasticidades de deman da está ligado ao fato das margens de comercialização serem relativamente rígidas. Isso porque a demanda a qualquer nível deriva-se da demanda do consumidor pela subtração da margem. Esta, por sua vez, depende intimamente da natureza das ofertas dos insumos não-agrícolas usados na comercialização, os quais tendem a ser relativamente elásticos, isto é, os preços daqueles insumos são relativamente mais estáveis quando comparados aos preços dos produtos agrícolas.

Um dos objetivos das políticas de comercialização é reduzir as variações de preço. Para se atingir tal objetivo algumas recomendações podem ser feitas. Primeiramente, deve-se lembrar que 
dada a relação entre as demandas nos diferentes núveis de mercado, dificilmente os preços ao nível do produtor deixarão de set os que mais variam. No entanto, tais variações podem ser controladas pela regularização do fluxo comercializado. Por exemplo, quanto menor for a discrepância entre as quantidades comercializadas na safra e na entressafra, menores serão as variaçães de preço a cada nível, apesar das variações ao nível do produtor serem sempre relativamente maiores que aquelas ao nível do atacado ou do varejo. Deduz-se daf a importância de polfticas que visassem aumentar a capacidade armazenadora e que estimulassem o uso da mesma. Desse modo, polfticas de ampliação da rede de armazenagem, do volume de crédito para tal fim, bem como de disponibilidade de informações de mercado, poderiam ser eficazes na redução das oscilações de preço.

Quanto à análise referente ao comportamento dos usuá rios dos armazéns existentes, verifica-se que eles tendem a respon der às variações de preço, sendo a resposta no sentido de atenuar essas variações. Conclui-se então que estímulos deveriam ser dados no sentido de incrementar a utilização dos armazéns. Lembre-se a es se respeito a baixa proporção da produção do Estado que passa pela CEAGESP.

Aparentemente, o crédito para a comercialização e a disponibilidade de informação de mercado poderão ter um importante papel a cumprir na redução das variações de preço e na regularização do abastecimento de milho. No que diz respeito ao crédito, ha- 
veria que se considerar não somente a possibilidade de um incremento puro e simples do crédito rural, mas também os possíveis benefícios de uma realocação do mesmo, de forma a se transferir parte dos recursos atualmente destinados à produção para a fase da comerciali zação. 
86.

\section{SUMMARY}

The objective of the present study was to analyze several aspects of the decision to store corn and prices behavior in the State of São Paulo. The introduction describes the problem and its importance. The following chapter includes a review of literature.

The chapter on methodology describes the data utilized and the methods employed in the study. Then, the analysis of the marketing margin as well at its econometric analysis are discussed. From the latter, the elasticity of price transmission is calculated. Also in this section the method for analyzing seasonal variation in prices by utilizing the moving geametric average is presented. Finally, the model for analyzing the price expectation effect on storage of corn in the CEAGESP warehouses is discussed. For this, a 
distributed lag model was used.

The results obtained showed that the average marketing margin for corn in the State of São Paulo in the period 1965/75 was around $43.9 \%$ of the retail price. Average participation of the farmer in the retail price was $56.1 \%$ for the period under study; that of the retailer was $30.5 \%$ and of the wholesaler, $13.4 \%$. With regard to the econometric analysis, the relative markup showed a decreasing tendency during the whole period for the 3 levels. Therefore, the hypothesis that the absolute margin is constant cannot be rejected. Analysis of the elasticity of price transmission showed that it was consistently less than 1 . During the period 1965/75 those elasticities averaged $0.4,0.76$ and 0.47 , respectively, for total, wholesale, and retail elasticities.

The range of variation of the seasonal index was 28.3 for the farmer, 20.7 for the wholesaler and 14.5 for the retailer. Therefore, the price received by the farmer showed greater variation than that received by the wholesaler which, in turn, showed greater variation than that received by the retailer.

Analyzing the data an amount of corn stored in the CEAGESP warehouses during the period 1965/76, it was found that in average, corn occupied $14 \%$ of total capacity, which represents $7.1 \%$ of the average production in the State during that period. With regard to future price expectations of CEAGESP users, the results were as follows: (a) short run price elasticity 
(with respect to current-month price) suggests that a $10 \%$ variation in current-month price will bring about a $6.3 \%$ variation in current stocks in relation to previous month, but in the opposite direction; (b) the long run price elasticity (with respect to price expected for the following month) suggests that a $10 \%$ variation in the price expected for the following month in relation to current-month price leads to a $10.9 \%$ variation in stocks, in the same direction. Theoretical and political implications drawn from the results obtained emphasize the role of credit policies for marketing and storing which aim at reducing price fluctuations and regulating the supply of corn. 
89.

\section{LITERATURA CITADA}

ANPES - Associação Nacional de Programação Econömica e Social, 1974. coord. PASTORE, A.C. e ARAUJO, P.F.C. Pecuária de corte, Trigo, Soja, Milho e Sorgo: Produção, Comércio e Política. São Paulo, 224 p. (mimeo).

BRANDT, S.A., 1964. Flutuações de Preços e Estrutura da Demanda da Banana no Mercado de São Paula. Agricultura em São Paulo. IEA. São Paulo, 11(8/12):1-40.

BRANDT, S.A., 1969a. Curso de Pós-Graduação de Comercialização Agrí cola. Viçosa, UFV. 146 p. (mimeo).

BRANDT, S.A., 1969b. Anälise Econométrica das Margens de Comercia1ização. Anais da VII Reunião da Sociedade Brasileira de Economistas Rurais. Piracicaba, vol. III:70-107.

BRANDT, S.A., (s.d.). Pesquisas em Margem de Comercialização. Viçosa, Escola de Especialização, 12 p. (mimeo). 
CASTRO, A.B. de, 1972. Aspectos da Interdependência Econômica entre a Estrutura do Consumo e a Comercialização Agrícola. Piraci caba, ESALQ/USP, 100 p. (Tese de Doutoramento) (mimeo).

CARMO, I.M., 1969. Análise da Comercialização da Carne Bovina no Estado de São Paulo. Piracicaba, OCSA/ESALQ. 87 p. (Tese de MS) (mimeo).

DIAS, R.A., 1972. Comercialização Agrícola. Boletim do Alto Conselho Agrícola. Sec. da Agricultura do Est. de São Paulo, 45 p.

FRAGA, Constantino C., 1960. Considerações sobre uma Política de Abastecimento. Agricultura em São Paulo. IEA. São Paulo, 7(7): $1-15$.

GARDNER, B.L., 1975. The Farm-Retail Price Spread in a Competitive Food Industry. American Journal Agr. Econ. August, p. 399 a 409.

GEORGE, P.S. e King, G.A., 1971. Consumer Demand for Food Commodities in the United States With Projections for 1980. - Giannini Foundation of Agricultural Economics - University of California Division of Agricultural Sciences, $p .53$ a 61 .

HARDIN, L.S., 1962. Crescimento e Desenvolvimento Profissional em Economia Rural. Anais da III Reunião da Sociedade Brasileira de. Economistas Rurais. Viçosa, Minas Gerais, p. 171.

HOFFMANN, R。, 1969a. Variação Estacional dos Preços de Produtos Agropecuários no Estado de São Paulo. Piracicaba, DCSA/ESALQ, 184 p. (Tese de Dr.) (mimeo). 
HOFFMANN, R., 1969b. Anälise Econométrica da Margem de Comercialização de Ovos no Estado de São Paulo. PIracicaba, DCSA/ESALQ, Série Didática $n^{8} 10,18 \mathrm{p}$. (mimeo).

HOFFMANN, R. e CROCOMD, C.R., 1972. Varıação Estacional de Produtos Hortícolas no Estado de São Paulo, no período 1964/71. Piracicaba, ESALQ/DCSA, Série Pesquisa n $n^{8} 18,93$ p. (mimeo).

JOHNSTON, J., 1972. Econometric Methods. 2nd Edition. McGraw-Hill Book Company, New York, 437 p.

JUNQUEIRA, P.C., 1967. Problemas de Comercialização no Brasil.

Anais da V Reunião da Sociedade Brasileira de Economistas Rurais. Rio de Janeiro, P. 153 a 181.

JUNQUEIRA, P.C., 1970. Distribuição das Margens de Comercialização. Guia de Comercialização Coopercotia. p. 86 a 94.

JUNQUEIRA, P.C. et alii, 1968. Comercialização de Produtos Agrícolas no Estado de São Paulo. Agricultura em São Paulo. IEA, São Paulo, 15(1/2):13-32.

KMENTA, Jan, 1971. Elements of Econometrics. The Macmillan Company, New York, 655 p.

KOHLS, R.L., (s.d.). O Problema de Mercado. (Trad. de parte do cap. 1 - "The Marketing Problem" de Marketing of Agriculture Products, Inc. 1955, P. 3-15). Viçosa, Escola de Especialização, 12 p. (mimeo).

LANGE, 0., 1967. Introdução à Econometria. Ed. Fundo de Cultura, 28 ed., Brasil, p. 23 a 75. 
MOSHER, A.R., (s.d.). "Getting Agriculture Moving". Essential for Development and Modernization. Traduzido por Donald W. Larson, ESALQ/OCSA, $14 \mathrm{p}$. (mimeo).

NERLOVE, M., 1958. Distributed Lags and Demand Analysis for Agricultural and Other Commodities Agricultural Marketing Service. USDA, Agriculture Handbook $n^{9} 141,121 \mathrm{p}$.

PANIAGO, E., 1966. Flutuações Estacionais no Preço do Milho no Estado de São Paulo. Revista Ceres. Viçosa, 13(73):66-80.

PEREIRA, I.F. et alii, 1963. Variação Estacional dos Preços Agríco las no Estado de São Paulo. Agricultura em São Paulo. IEA, São Paulo, $10(4): 3-67$.

PIMENTEL GOMES, F., 1976. Curso de Estatistica Experimental. Ed. Nobel, São Paulo, 6a. ed., ampliada, 404 p.

SÃo PAULO - Sec. da Agricultura - IEA, 1975. Prognóstico 75/76. São Paulo, p. 163 a 170.

SPIEGEL, M.R., 1972. Estatística. Ed. MacGraw Hill do Brasil. São Paulo, $580 \mathrm{p}$.

STEELE, H.L. et alii, 1971. Comercialização Agrícola. São Paulo, Ed. Atlas S.A., $443 \mathrm{p}$.

SUPLAN, 1975. Subsídios aos Palnos Anuais de Produção e Abastecimento - Milho. Ministério da Agricultura, DF, 47 p.

WALDER, V.M., 1976. Padrões Estacionais de Preços e Polftica de Es tocagem de Produtos Agropecuários. Viçosa, Imprensa Universitária. (Tese de MS). (mimeo). 
93.

APENDICE I

Dados Originais do Trabalho 


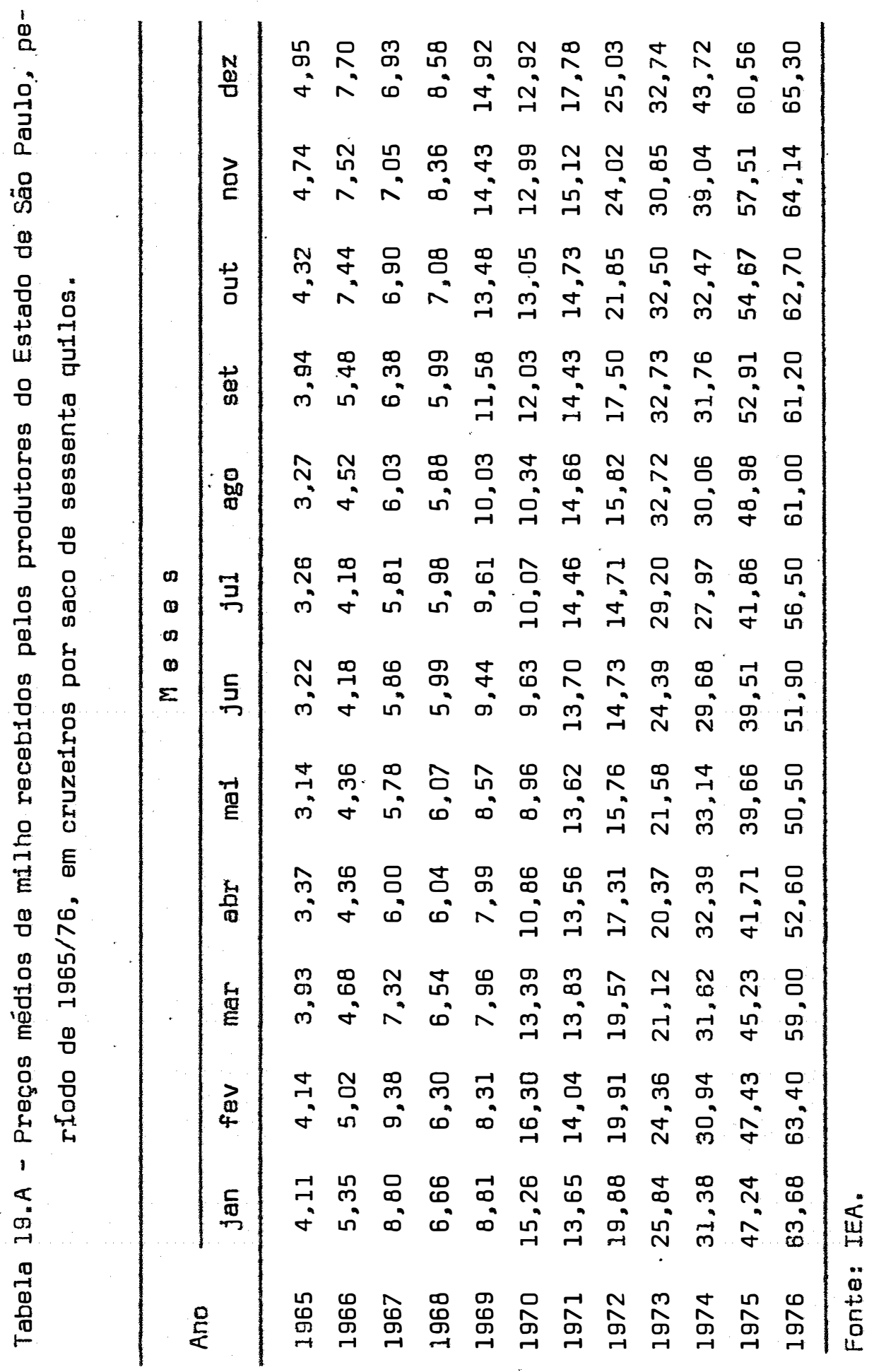




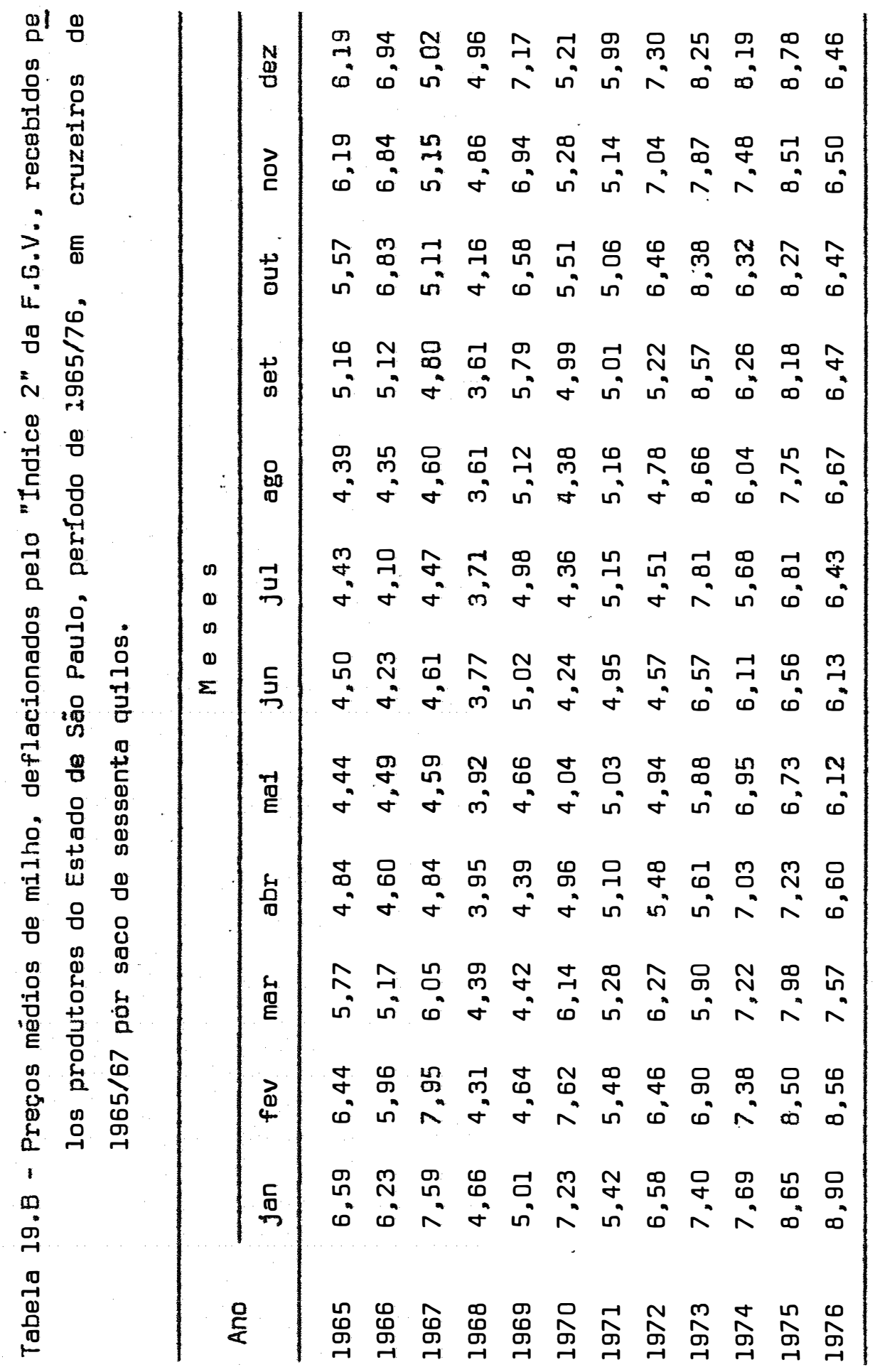




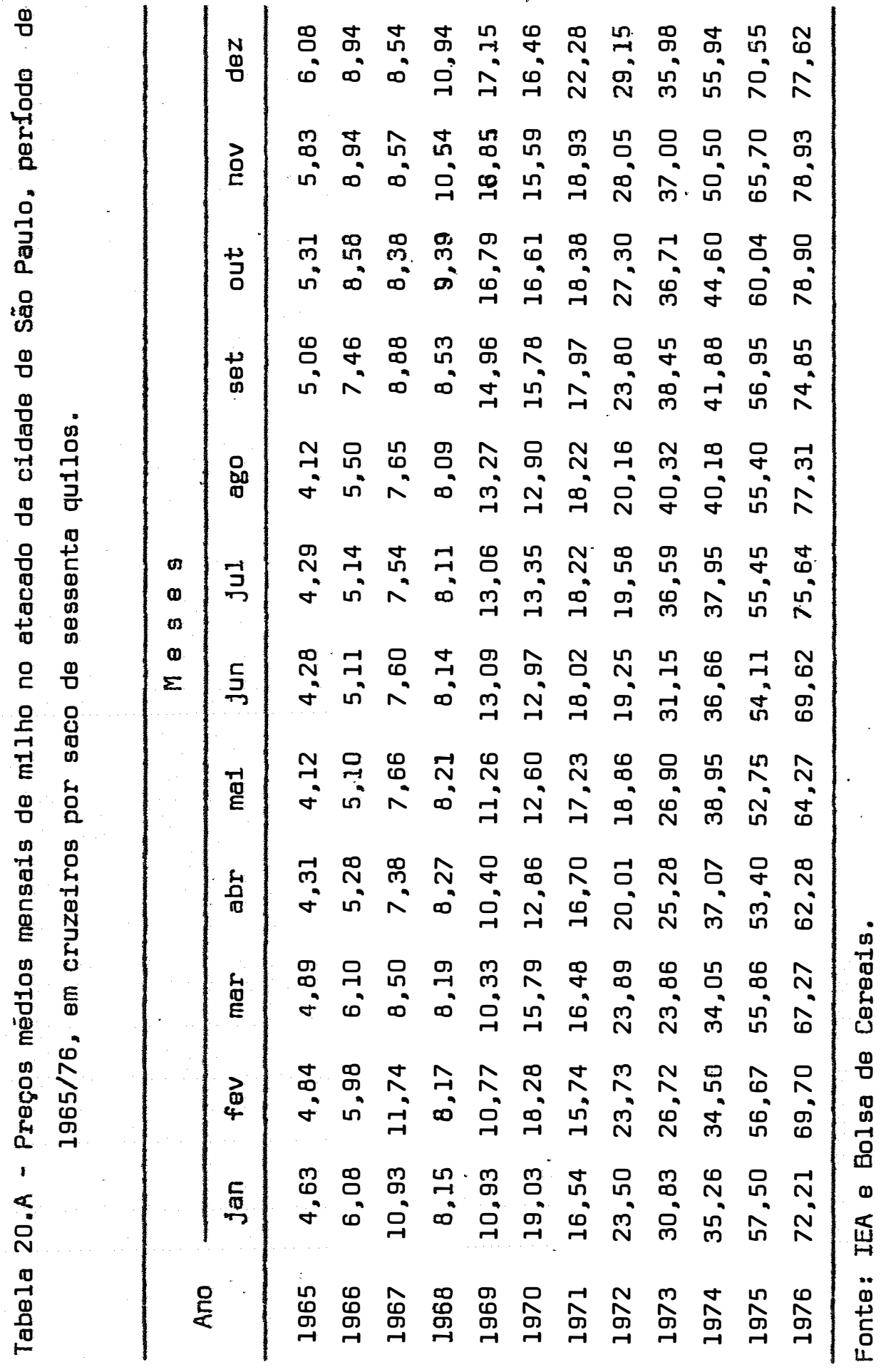




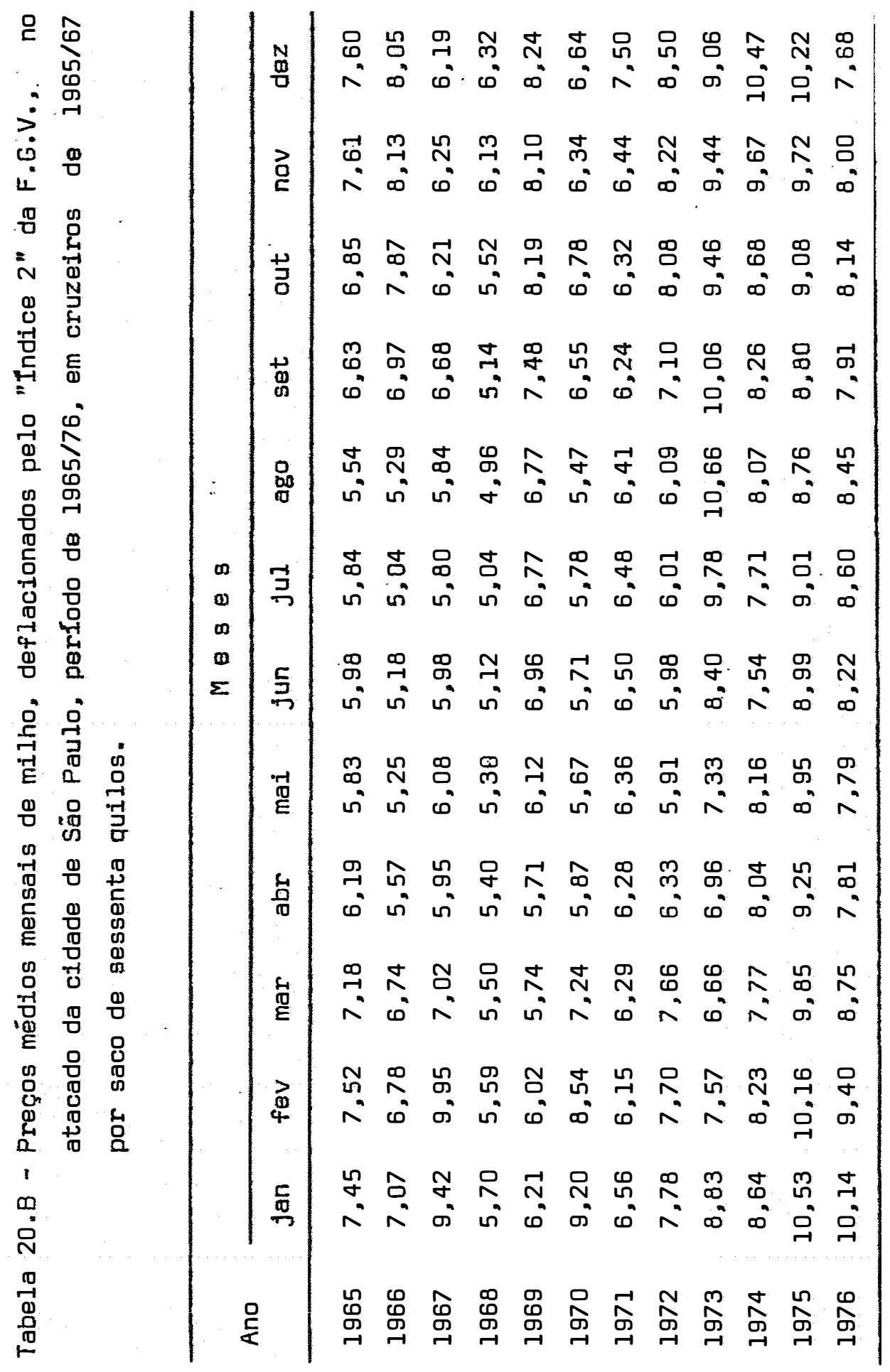




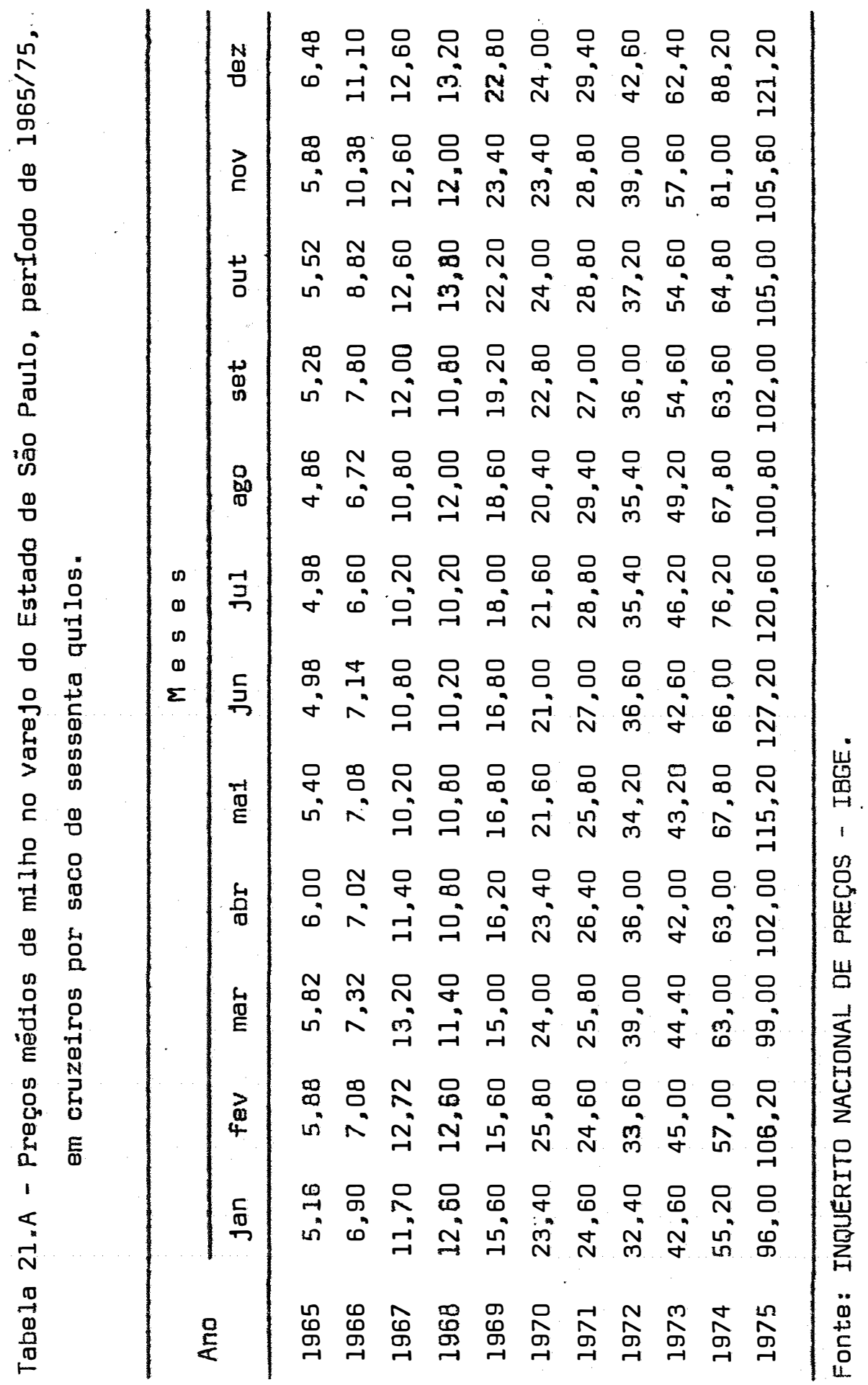




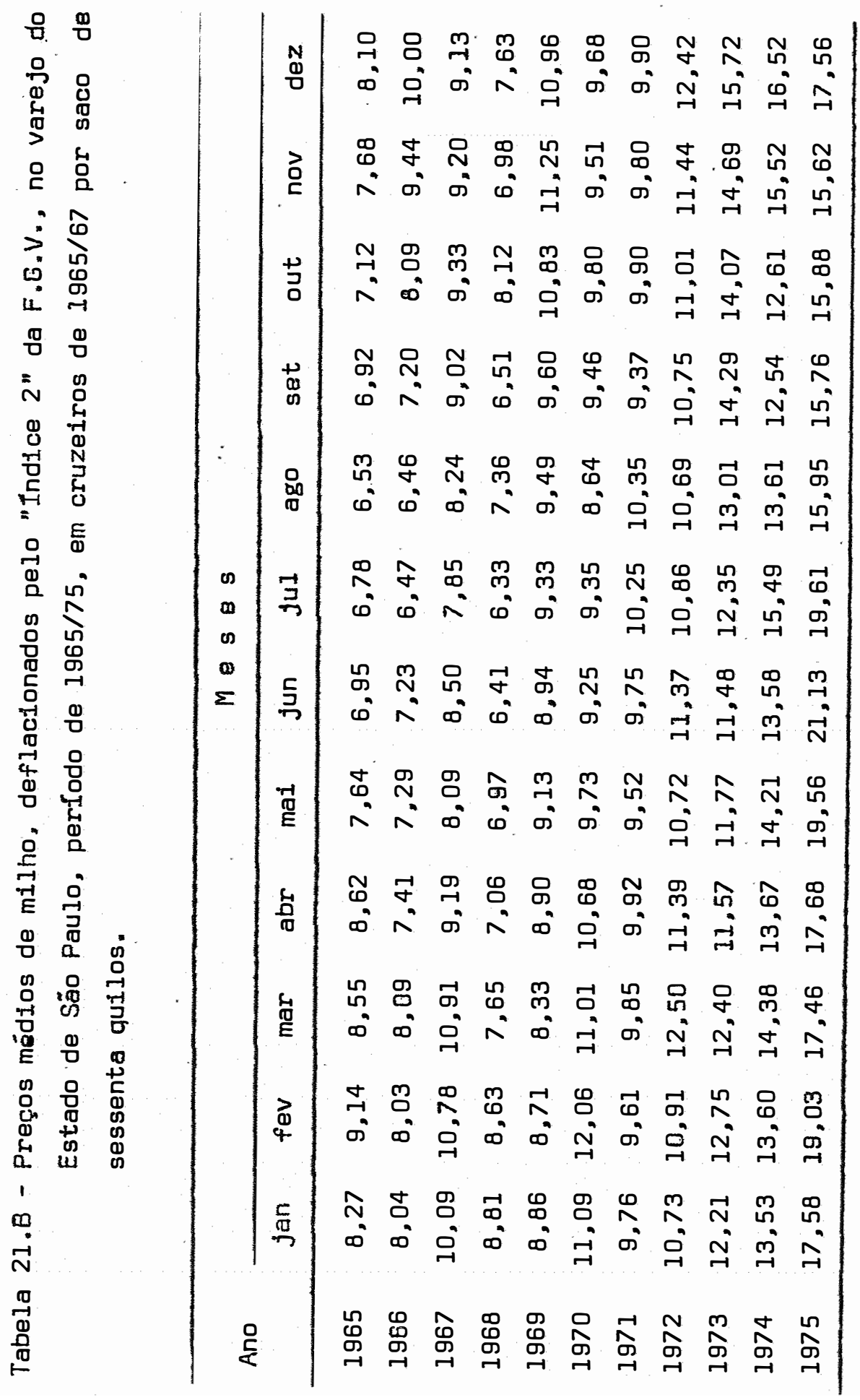


100.

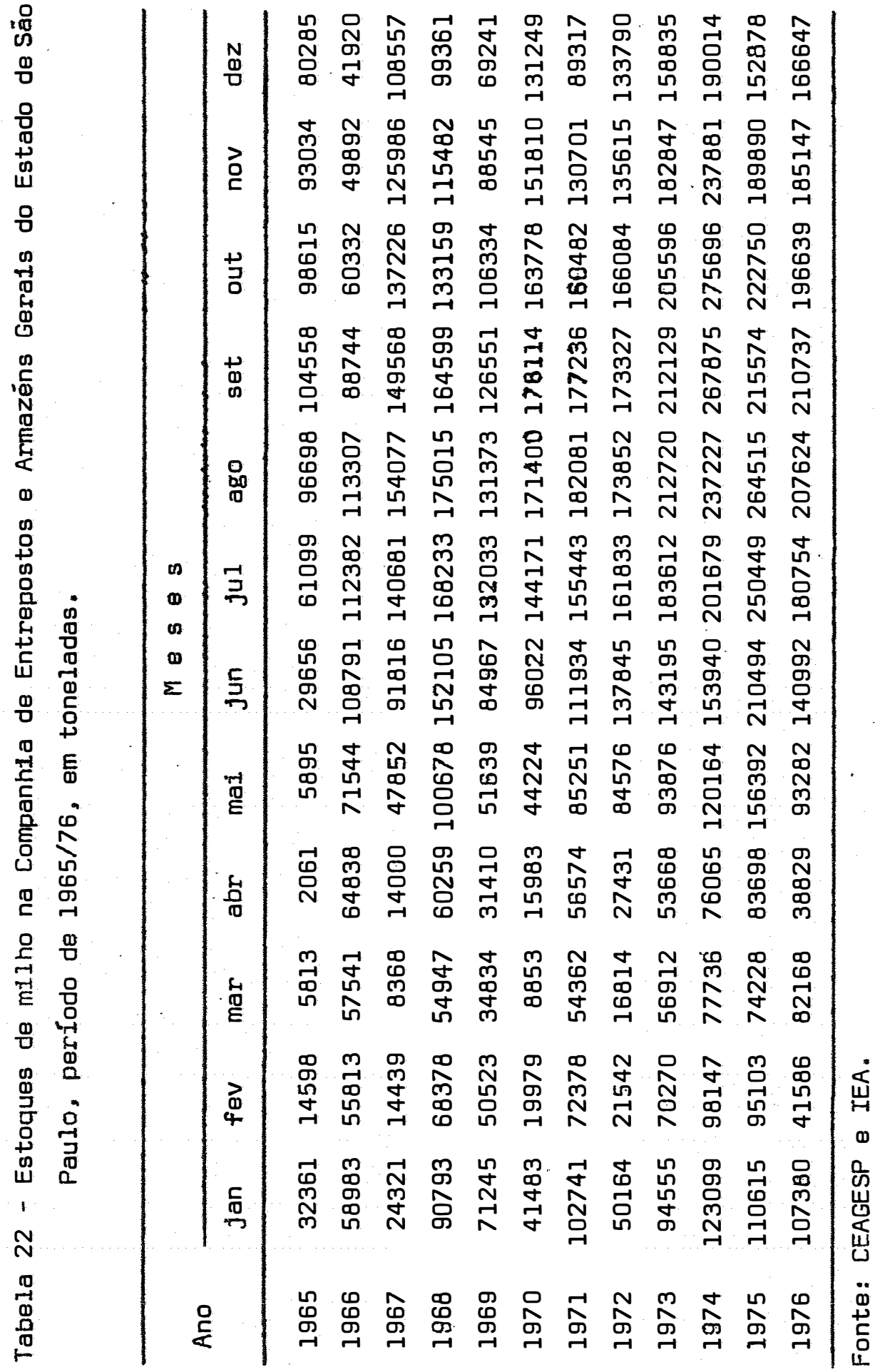


101.

APENDICE 2

Quadros de Resultado das Margens de Comercialização 


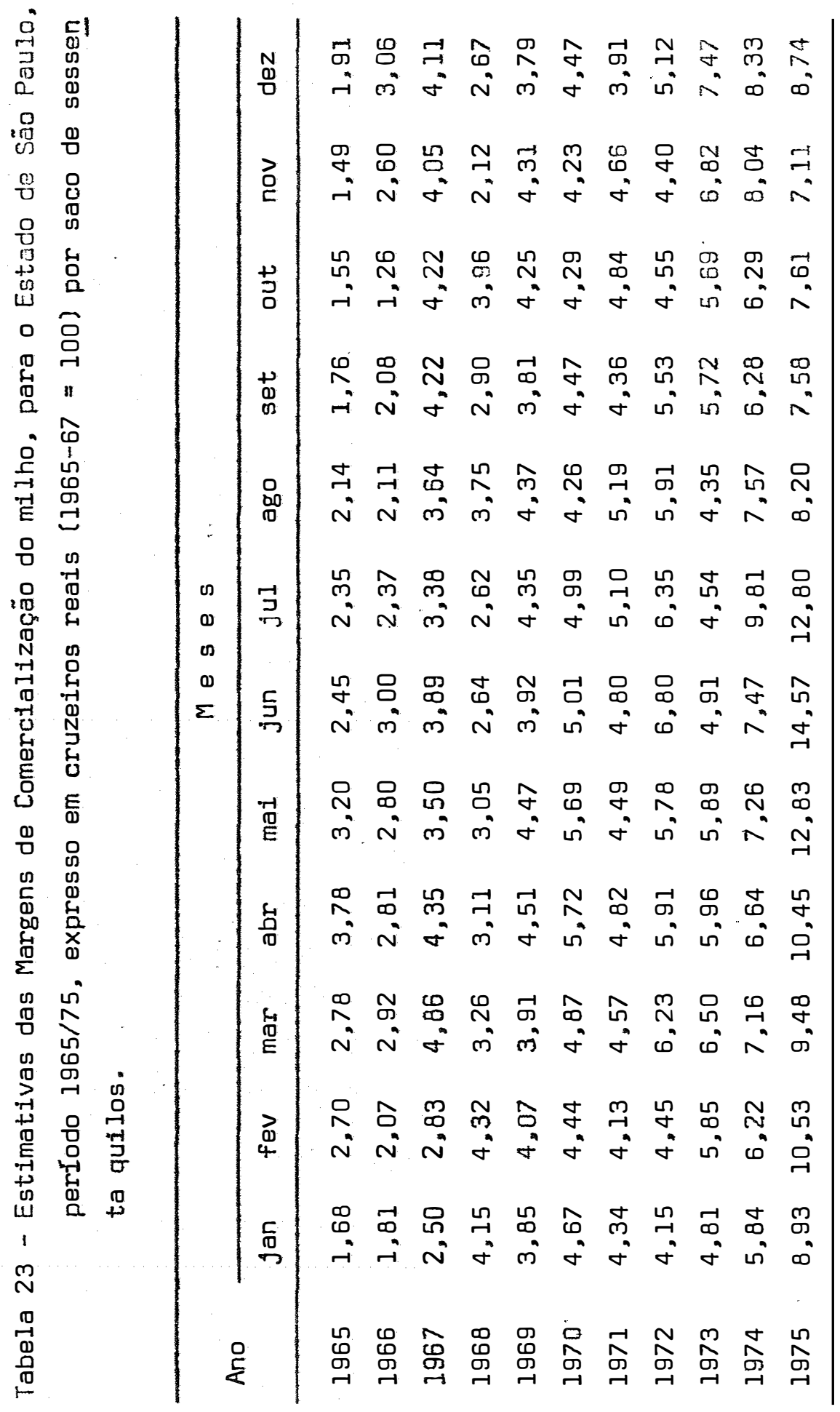




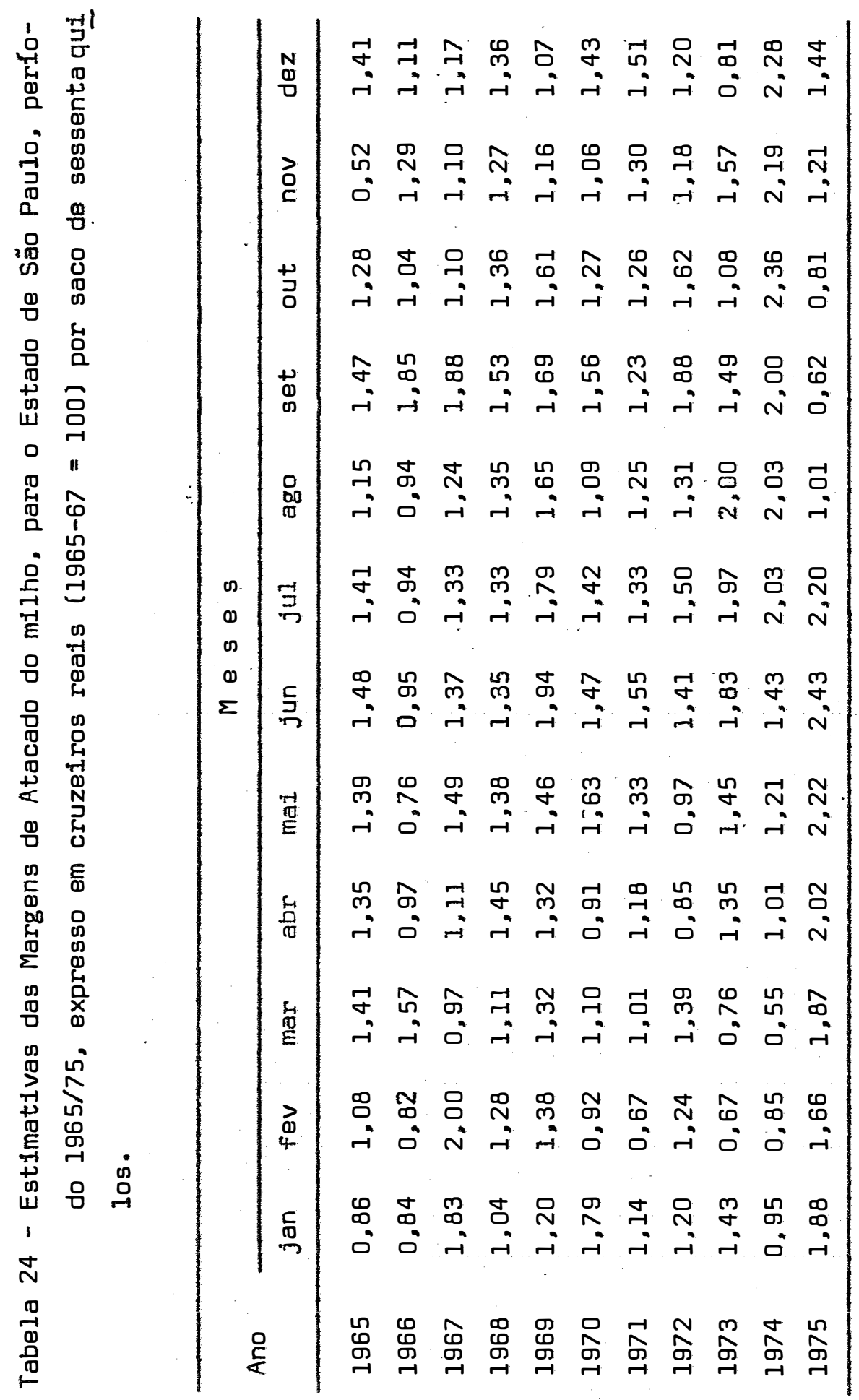




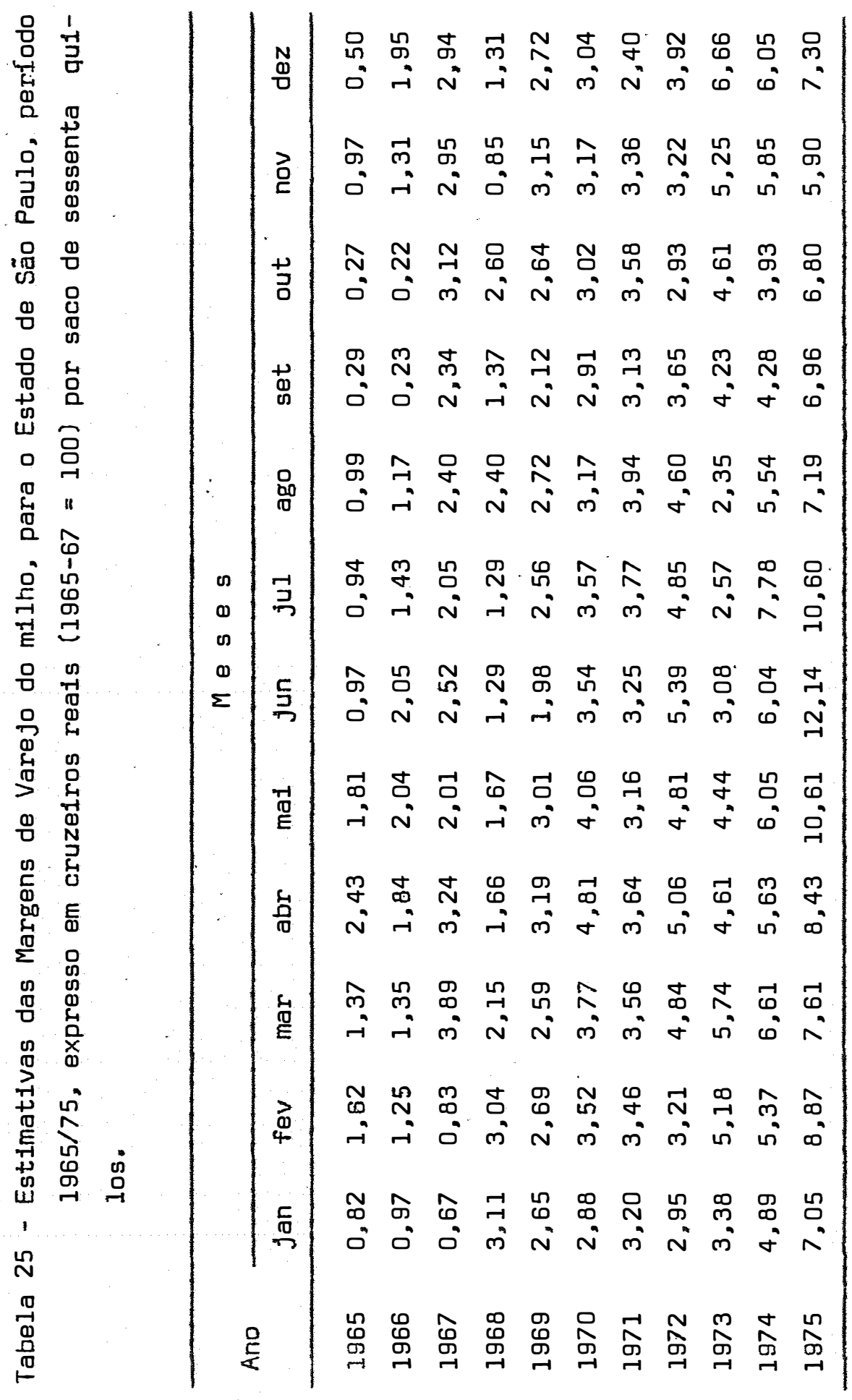




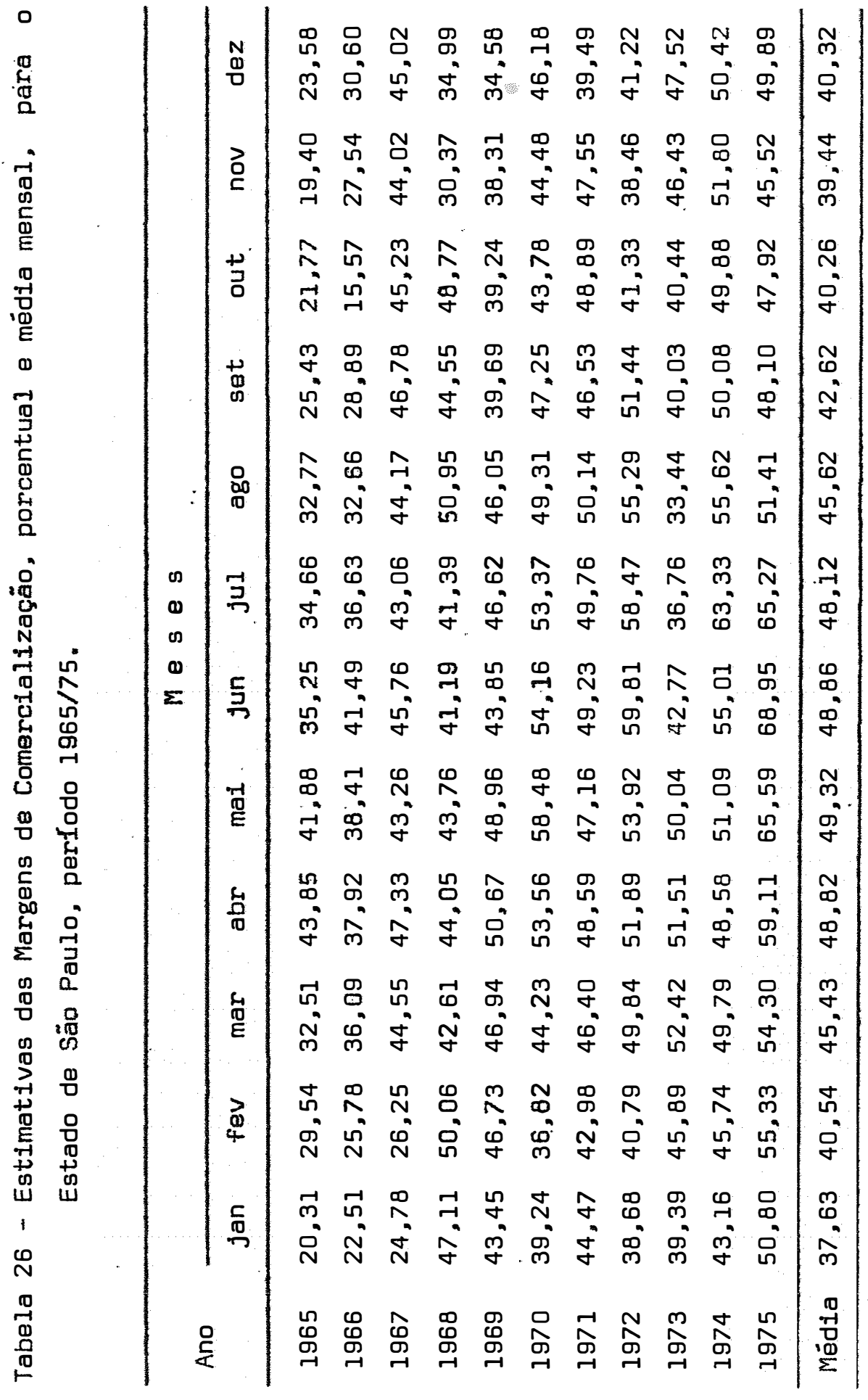




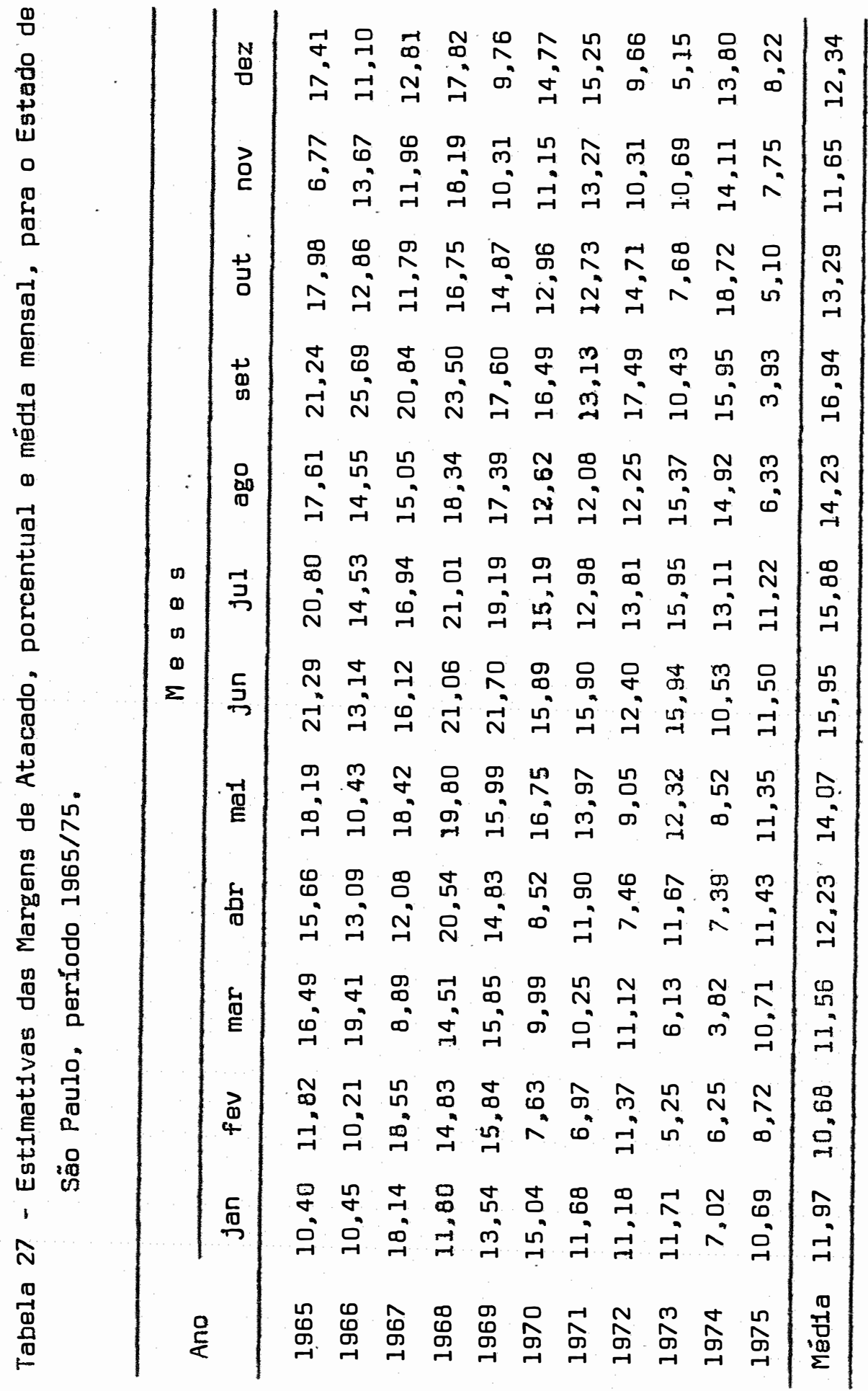




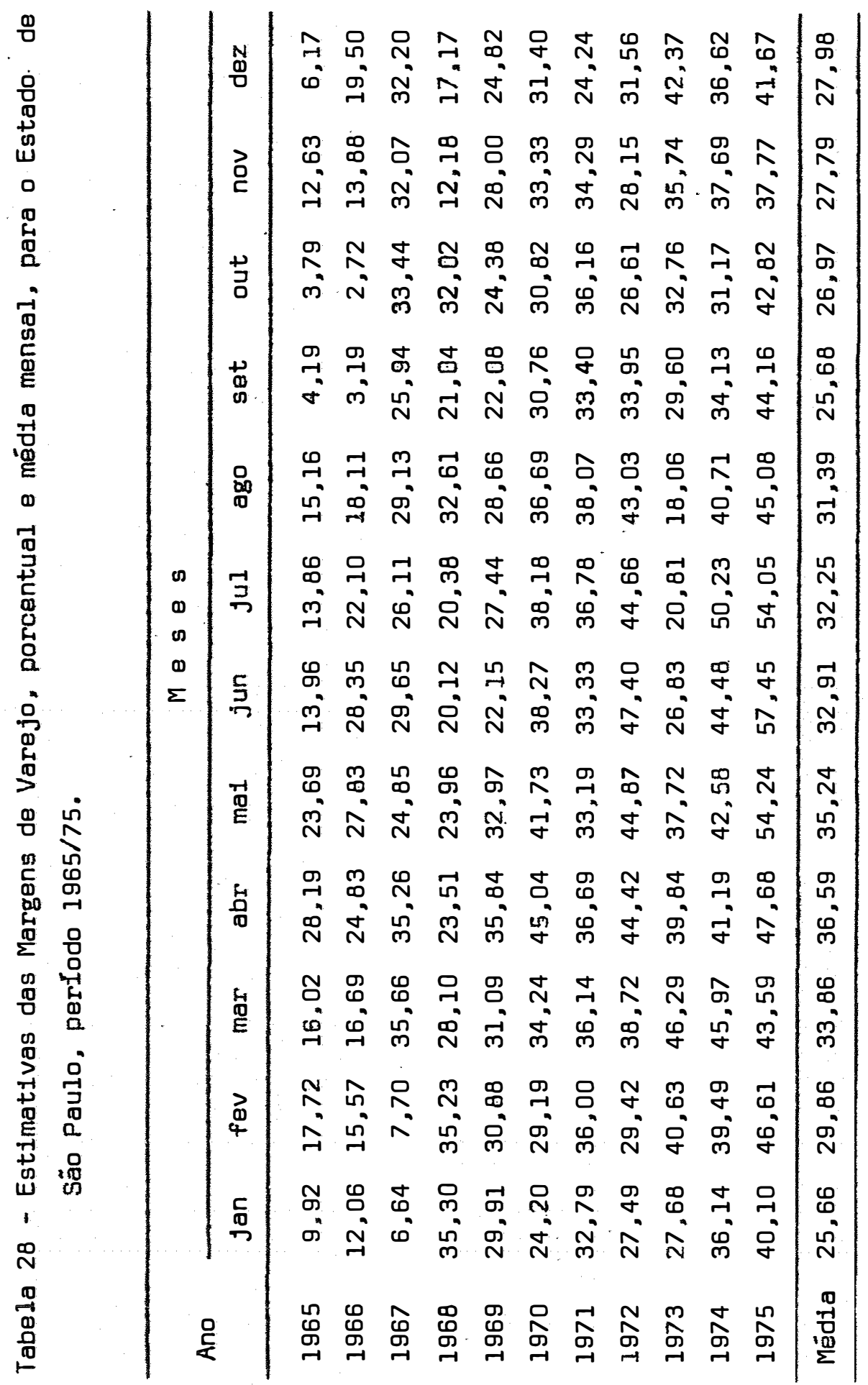




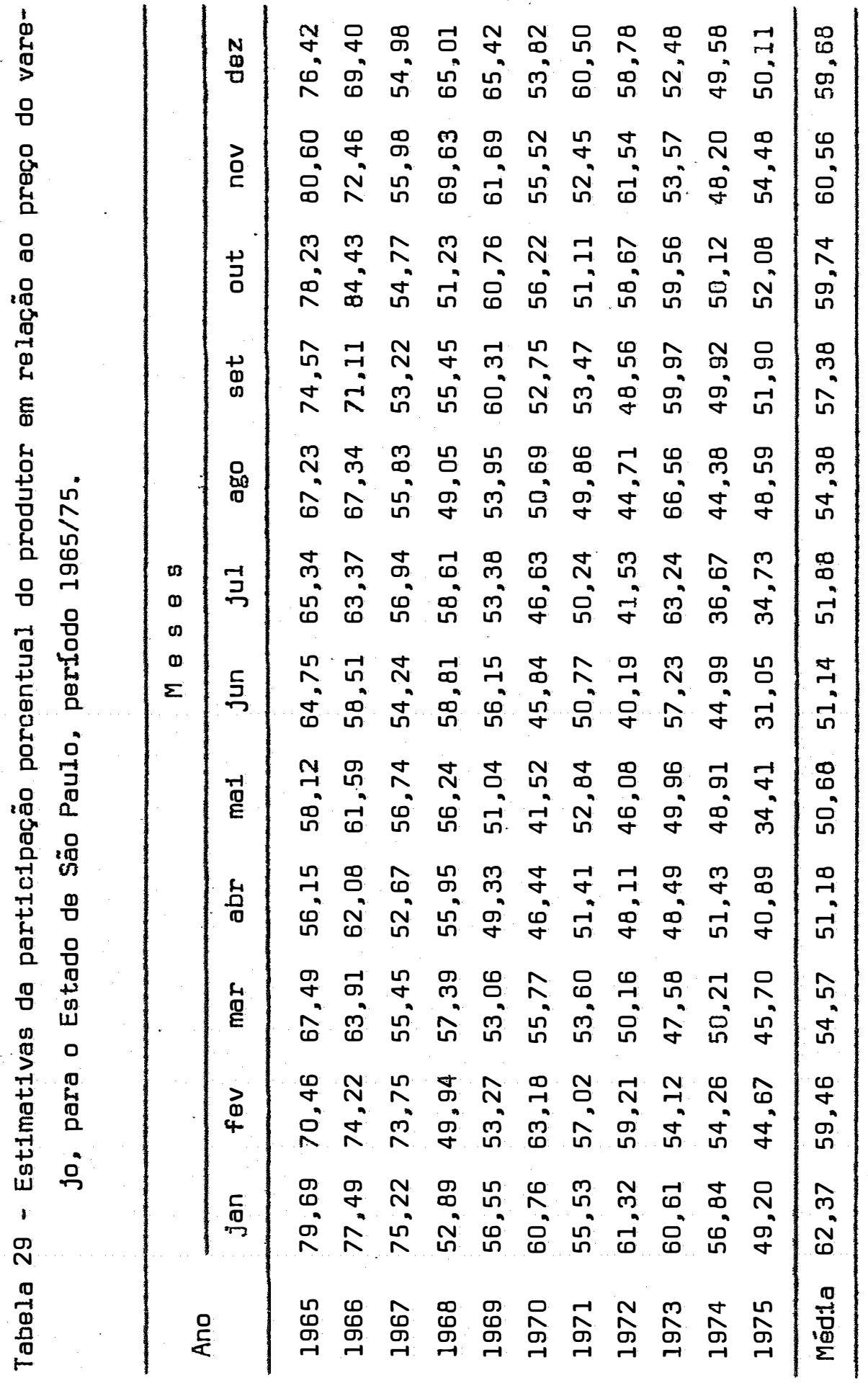




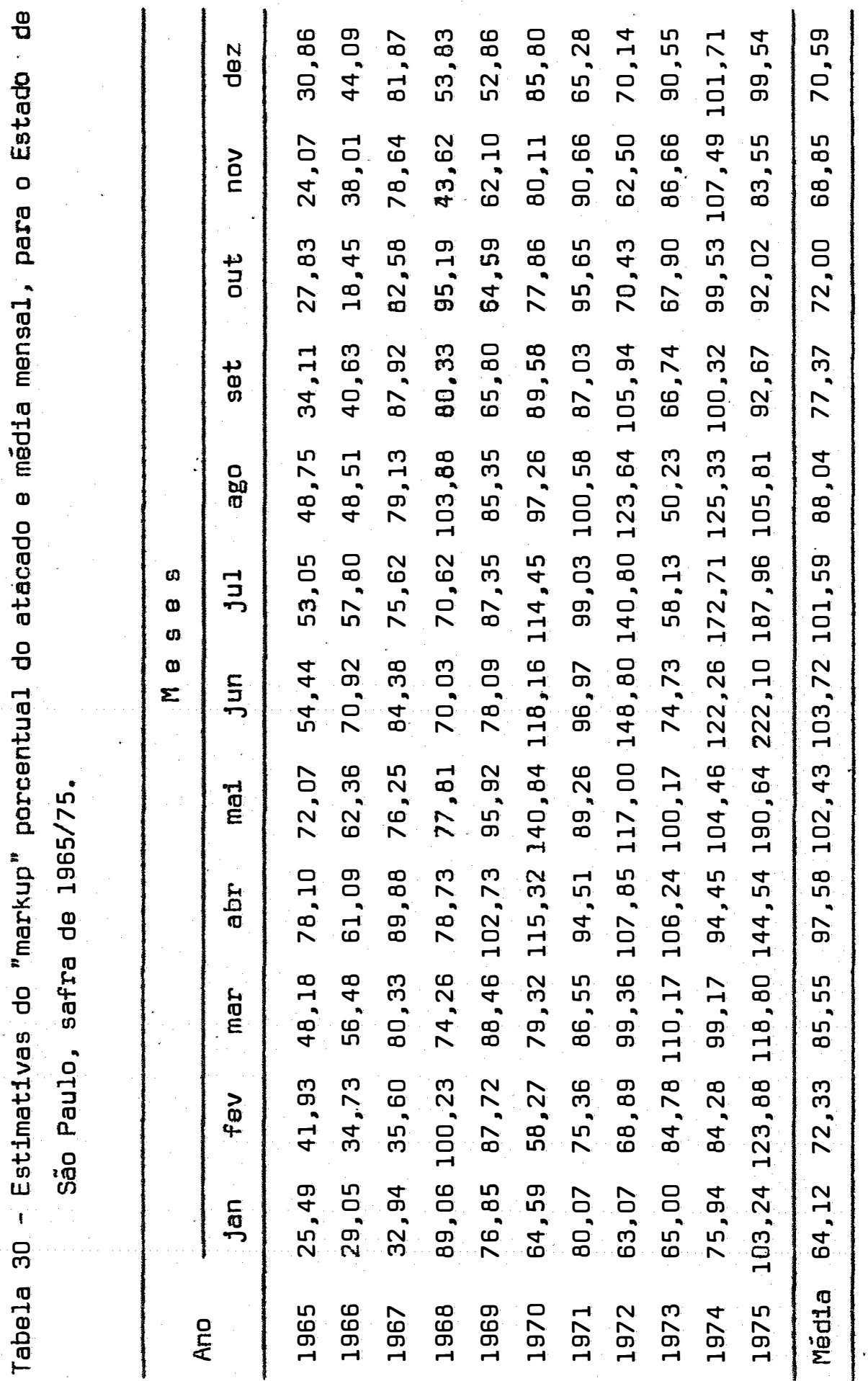




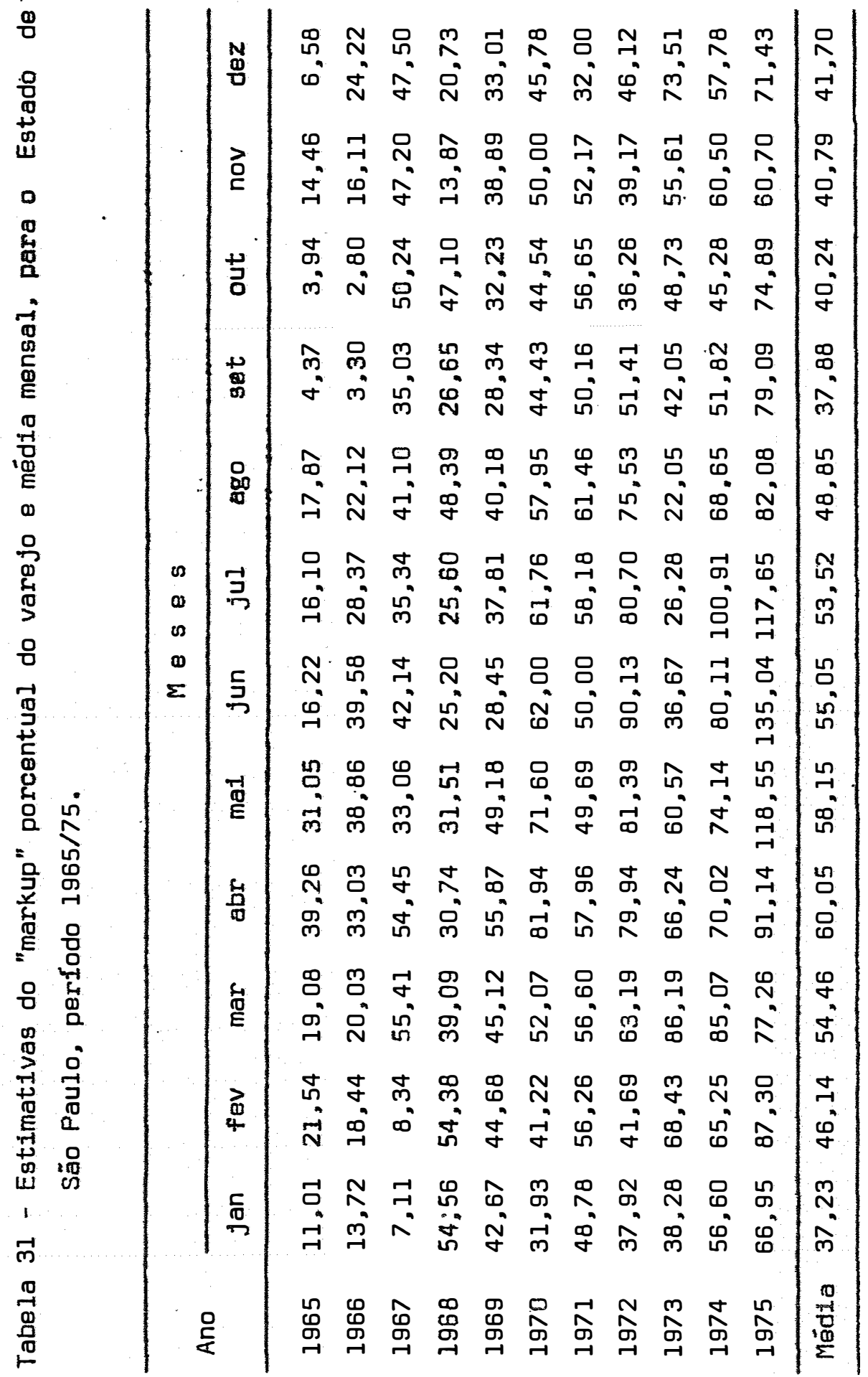


111.

APENDICE 3

Anälise de Variância dos Indices Sazonais 
Tabela 32 - Análise de variàncla dos fndices do produtor.

\begin{tabular}{lcccc}
\hline C. de variação & G.L. & S.Q. & Q.M. & F \\
\hline Meses & 11 & 1,418 & 0,1289 & 16,74 \\
Residuo & 120 & 0,926 & 0,0077 & \\
\hline Total & 131 & 2,344 & & \\
\hline & & $R^{2}=0,605$
\end{tabular}

Tabela 33 - Análise de variàncla dos fndices do atacado.

\begin{tabular}{lcccc}
\hline C. de variação & G.L. & S.Q. & Q.M. & F \\
\hline Meses & 11 & 0,742 & 0,0674 & 9,23 \\
Resfduo & 120 & 0,877 & 0,0073 & \\
\hline Total & 131 & 1,619 & & \\
\hline & & $R^{2}=0,458$
\end{tabular}

Tabela 34 - Análise de variàncla dos Indices do varejo.

\begin{tabular}{lcccc}
\hline C. de varlação & G.L. & S.Q. & Q.M. & F \\
\hline Meses & 11 & 0,282 & 0,0256 & 4,74 \\
Residuo & 108 & 0,586 & 0,0054 & \\
\hline Total & 119 & 0,868 & & \\
\hline & & $R^{2}=0,325$
\end{tabular}

